UNIVERSIDADE DE SÃO PAULO
INSTITUTO DE QUÍMICA DE SÃO CARLOS

\title{
DIAGNÓSTICO DE DOENÇAS DE CITROS UTILIZANDO ESPECTROSCOPIA DE FLUORESCÊNCIA
}

\section{Ana Flávia Zaghi}

Dissertação apresentada ao Instituto de Química de São Carlos, da Universidade de São Paulo para obtenção do título de Mestre em Ciências (Química Analítica).

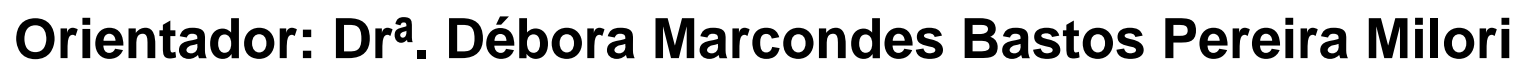
Embrapa Instrumentação Agropecuária - São Carlos

São Carlos

2008 
"Aqueles que calculam cuidadosamente suas estratégicas serão conduzidos à vitória. Aqueles que calculam suas estratégias sem cuidado serão conduzidos à derrota" Sun $\mathcal{T} z u$ 


\section{Dedico}

Aos meus pais, Otaviano e Sueli por estarem sempre ao meu lado confiando de maneira incondicional em mim.

Só tenho a agradecer tudo que vocês fizeram e fazem por mim. A vida fica muito mais leve e colorida sabendo que tenho vocês comigo sempre!

\section{Amo muito vocês!}

Ao meu irmão, Otavio Augusto que apesar de não estar ai meu lado fisicamente sempre estará dentro do meu coração !

Te amo de mais! 


\section{Agradecimentos}

À minha família pelo constante apoio, carinho e pela nossa união que me deixa segura para vida: Papai, Mamãe, vovô Gabriel e a vovó Maria que apesar de não entenderem muito meu trabalho acham que sou a pessoa mais inteligente do mundo, a tia Cila e a minha Madrinha Mina e principalmente a tia Bilinha e a Tia Cleuza pelo carinho e amizade.

Aos meus amigos de toda vida: Ritoka, Mariana e ao Dr. Cajobi.

A minha orientadora Dra. Débora Milori pelo carinho, amizade e principalmente pela confiança a mim dedicada.

Aos meus amigos de laboratório: André, pela amizade verdadeira, pela ajuda intelectual e principalmente por ser companheiro até tarde nas limpezas das folhas, ao Gabriel, que foi responsável pelas noticias que mudaram o mundo, ao Cleber, Robson, Kelly, Ursula, Vivi, Ingrid, Metralha, Dr. Washington, Ednaldo, Raphael, Tim, Alex Paixão e a Fabíola. A todos vocês muito obrigada.

Ao CNPQ pelo apoio financeiro.

À Embrapa Instrumentação Agropecuária pela infra-estrutura e pelo excelente ambiente de trabalho.

Ao Instituto de Química de São Carlos da Universidade de São Paulo.

Ao Fundecitrus, Agrindus e a Fisher pelo apoio e fornecimento das amostras. 
SUMÁRIO

LISTA DE FIGURAS

LISTA DE TABELAS

LISTA DE ABREVIATURAS E SIGLAS

RESUMO

ABSTRACT

CAPÍTULO 1- INTRODUÇÃO . .15

CAPÍTULO 2 - REVISÃO BIBLIOGRÁFICA ................................................................................19

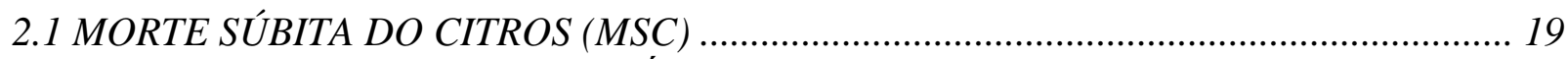

2.1.1 SINTOMAS DA MORTE SÚBITA DOS CITROS ............................................ 20

2.1.2 O PORTA-ENXERTO LIMOEIRO CRAVO................................................... 24

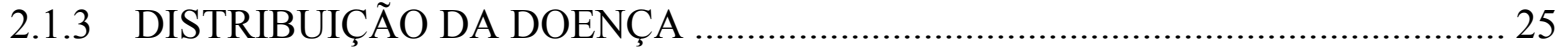

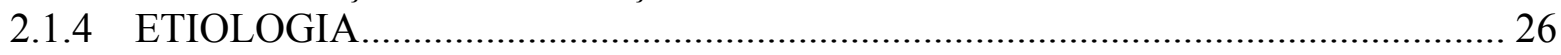

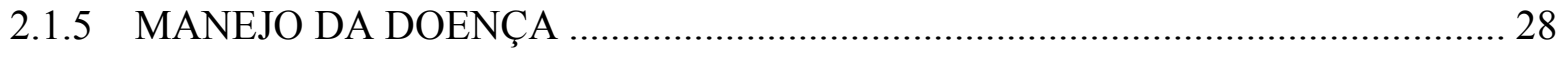

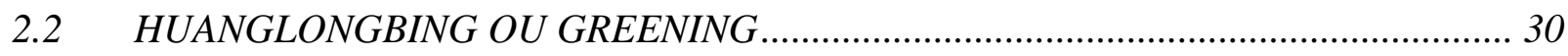

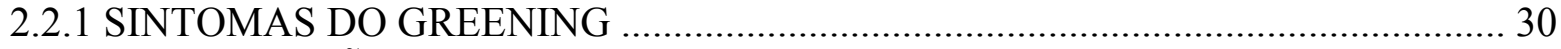

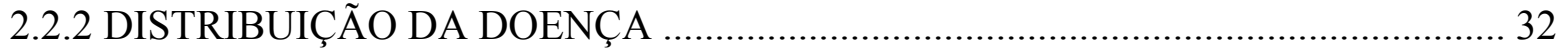

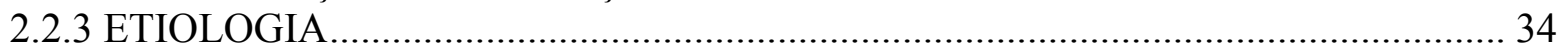

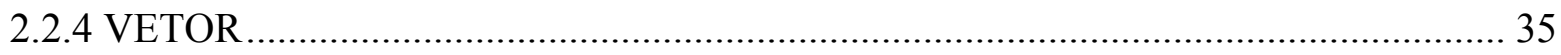

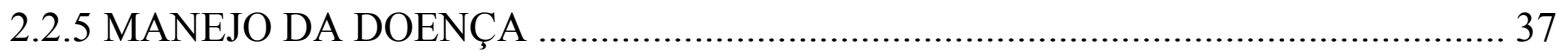

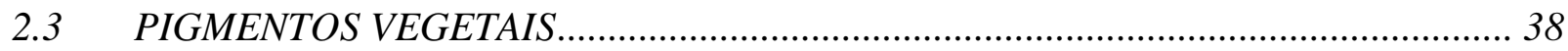

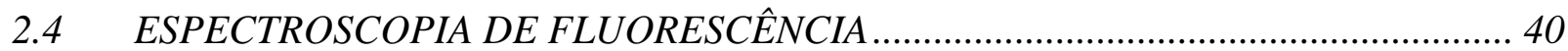

2.4.1 FLUORESCÊNCIA INDUZIDA POR LASER (FIL) ................................................ 43

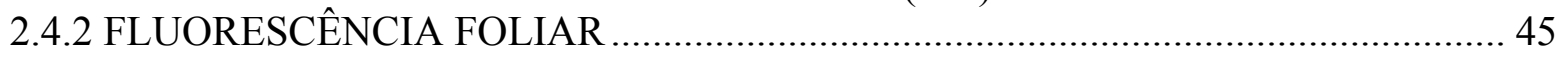

2.5 ANÁLISE DE COMPONENTES PRINCIPAIS (PCA) ............................................. 45

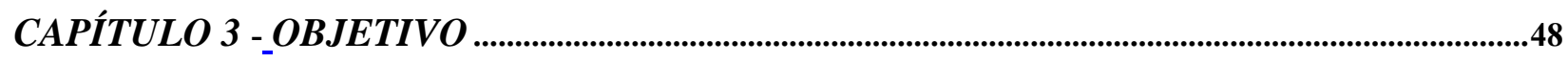

CAPÍTULO 4 - MATERIAIS E MÉTODOS .......................................................................................49

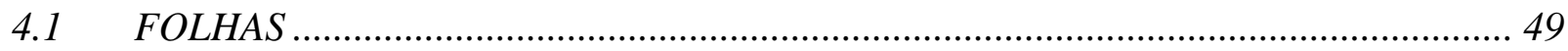

4.1.1 EQUIPAMENTO E METODOLOGIA PARA AQUISIÇÃO DOS DADOS .............. 51 
4.2 EXTRAÇÃO DOS PIGMENTOS FOTOSSINTÉTICOS ….............................................. 53

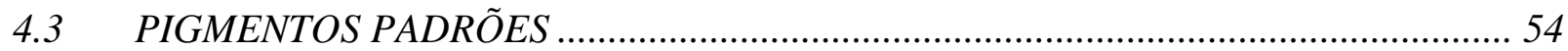

4.4 FORMA DE ANÁLISE DOS RESULTADOS ........................................................... 55

CAPÍTULO 5 -_RESULTADOS E DISCUSSÕES ………………………………………………......57

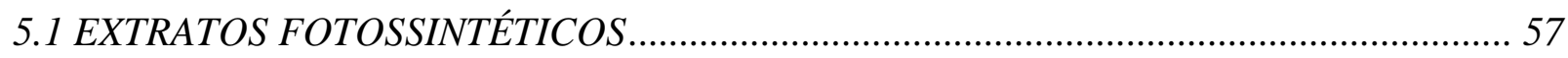

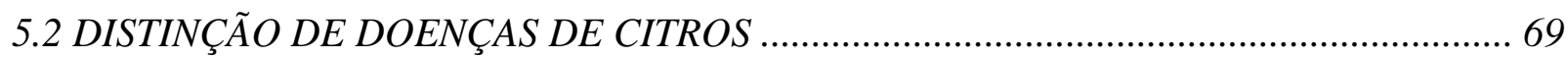

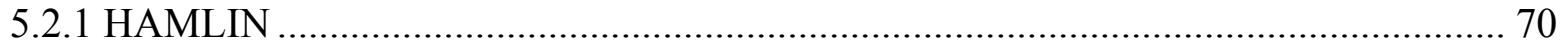

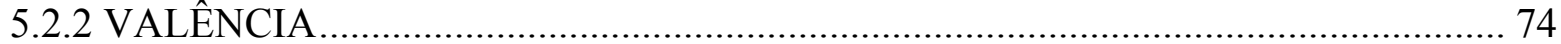

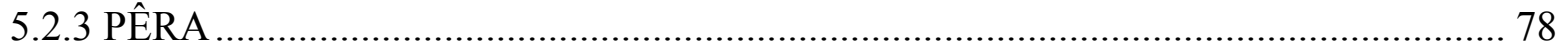

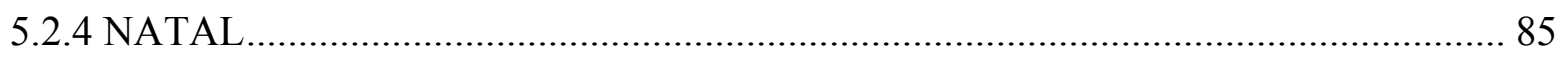

CAPÍTULO 6_CONCLUSÃO .............................................................................................................90

CAPÍTULO 7_SUGESTÕES DE TRABALHOS POSTERIORES ..................................................92

CAPÍTULO 8 -_REFERENCIA BIBLIOGRÁFICA …….....................................................................93 


\section{LISTA DE TABELAS}

Tabela 4.1 - Amostras fornecidas pela Fundecitrus de laranja Hamlin, Valência, e Pêra em portaenxerto de limão Cravo para análise de doenças

Tabela 4.2 - Amostras fornecidas pela Agrindus de laranja Pêra com porta-enxerto Sunki para analise de doenças.

Tabela 4.3 - Amostras fornecidas pela Agrindus de laranja Natal com porta-enxerto Trifoliata para análise de doenças .51

Tabela 4.4 - Extratos analisados de folhas de laranja Pêra enxertada em Limão Cravo e

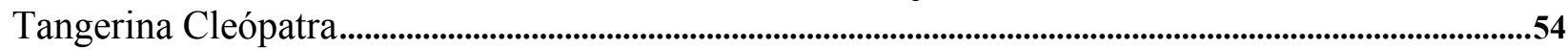

Tabela 5.1 - Valores gerados pelas gaussianas através do programa Pick Fit para extratos de folhas sadias da variedade Pêra enxertada em limoeiro Cravo.

Tabela 5.2 - Valores gerados pelas gaussianas através do programa Pick Fit para extratos de folhas com MSC da variedade Pêra enxertada em limoeiro Cravo. . .64

Tabela 5.3 - Valores gerados pelas gaussianas através do programa Pick Fit para extratos de folhas com Declínio variedade da Pêra enxertada em limoeiro Cravo

Tabela 5.4 - Valores gerados pelas gaussianas através do programa Pick Fit para extratos de folhas com Greening sintomática (GS) da variedade Pêra enxertada em limoeiro Cravo.

Tabela 5.5 - Valores gerados pelas gaussianas através do programa Pick Fit para extratos de folhas com Greening assintomática (GA) da variedade Pêra enxertada em limoeiro Cravo. .65

Tabela 5.6 - Valores gerados pelas gaussianas através do programa Pick Fit para extratos de folhas sadias da variedade Pêra enxertada em tangerina Cleópatra

Tabela 5.7 - Valores gerados pelas gaussianas através do programa Pick Fit para extratos de folhas com Declínio da variedade Pêra enxertada em tangerina Cleópatra. . .68

Tabela 5.8 - Valores gerados pelas gaussianas através do programa Pick Fit para extratos de folhas com Greening sintomática (GS) da variedade Pêra enxertada em tangerina Cleópatra. 


\section{LISTA DE FIGURAS}

Figura 2.1- Vista aérea de plantios de laranjeiras doce 'Valência' enxertada com limoeiro cravo, apresentando sintomas de MSC, e de laranjeira-doce 'Valência' enxertada com tangerina 'Cleópatra', sadia (A). Em (B) verifica-se duas linhas de plantio de laranjeira-doce 'Valência' enxertada em tangerina 'Cleópatra', sem sintomas da doença em meio de um plantio de laranjeira-doce 'Valência' enxertada em limoeiro 'Cravo', totalmente afetado pela doença. Fonte: Fundecitrus.

Figura 2.2 - Laranjeiras com sintomas da MSC mostrando perda de brilho generalizada e coloração verde-pálida das folhas, contrastando com a cor normal das plantas sadias (A) e folhas coletadas em plantas sadias e doentes, mostrando o contraste de coloração entre as mesmas (B). Fonte: Fundecitrus .. .21

Figura 2.3 - Coloração amarelada nos tecidos internos da casca do porta-enxerto limão 'Cravo', contratando com os tecidos brancos da copa (A) e comparação da coloração citada em (A) entre plantas sadias e doentes (B), mostrando que esse sintoma é típico de plantas com morte súbita dos citros. Fonte: Fundecitrus.

Figura 2.4 -Detalhe do sistema radicular da planta com sintoma inicial de MSC, o qual apresenta grande quantidade de raízes mortas, geralmente com poucas radicelas. Fonte: Fundecitrus............23

Figura 2.5 - Mapa da distribuição da morte súbita dos citros em SP e MG. Fonte: Jesus Junior et al., 2004b.

Figura 2.6- Subenxertia realizada em planta com seis anos de idade através da técnica do T invertido, utilizando-se dois cavalinhos. Fonte: Fundecitrus.

Figura 2.7 - Laranjeira com Greening mostrando o amarelecimento de galhos e folhas contrastando com o verde das folhas e ramos não afetados (A) e folhas contaminadas mostrando as irregularidades das manchas amareladas, chamadas de folhas mosqueadas (B). Fonte: Fundecitrus.

Figura 2.8 - Fruto de planta contaminada com Greening possui tamanho irregular e a casca verde pálido (A) e o corte longitudinal do mesmo mostram filetes alaranjados no pedúnculo e a diferença de maturidade do fruto e também uma maior espessura da parte branca do fruto (B). Fonte: Fundecitrus..

Figura 2.9 - Sementes sadias à esquerda e sementes abortadas a direita. As sementes abortadas possuem uma diferença de coloração, mais escuras.Fonte: Fundecitrus.

Figura 2.10 - Mapa da distribuição do Greening no estado de São Paulo, atingindo quase 200 municípios.

Figura 2.11 - Foto da florada (A) e do fruto (B) da Murraya paniculata, conhecida como murta, planta ornamental hospedeira da bactéria Candidatus Liberibacter. Fonte: Fundecitrus.....................36 
Figura 2.12 - Imagem da Diaphorina citri, inseto cinza, com $3 \mathrm{~mm}$ de comprimento e asas manchadas (A) o inseto a $45^{\circ}$ no ramo, característica peculiar da D.citri (B). Fonte: Vivernatural.

Figura 2.13 - Representação gráfica da clorofila a e da clorofila $b$, onde a diferenciação da clorofila a e b é apenas a substituição do radical R por um hidrocarboneto (clorofila a) ou por um aldeído (clorofila b).

Figura 2.14: Configuração energética de uma molécula orgânica e suas transições eletrônicas. ...41

Figura 2.15: Esquema do sistema portátil para realização de medidas de FIL(A) detalhe do funcionamento do mini-espectrômetro: (1) entrada de luz através de uma fibra óptica (2) e (3) sistema de acoplamento da fibra com o mini-espectrômetro (4) espelho plano (5) espelho esférico (6) grade de difração (7) sistema de detecção composto de um conjunto de fotodiodos calibrados (B).

Figura 4.1 - Foto ilustrativa de como foram feitas às medidas nas folhas. A sonda é levada até a superfície da folha Os dados adquiridos são armazenados em um banco de dados. .53

Figura 5.1 - Espectro de emissão de fluorescência com excitação em $560 \mathrm{~nm}$ de padrões de clorofila a, clorofila $\mathrm{b}$ e $\alpha: \beta$-caroteno diluído em acetona.. .58

Figura 5.2 - Espectro de emissão de fluorescência com excitação em 560nm correspondente a diferentes tipos de extratos. a) Variedade Pêra com porta-enxerto limão Cravo e b) Variedade Pêra com porta-enxerto tangerina Cleópatra. . .59

Figura 5.3 - Deconvolução dos espectros de emissão de Fluorescência com $\lambda_{\text {exc }}=560$ para os extratos de folhas de laranjeira Pêra com porta-enxerto de limão Cravo: a) sadia, b) MSC, c) Declínio, d) Greening sintomática, e) espectro de extrato Greening assintomática.

Figura 5.4 - Deconvolução dos espectros de emissão de Fluorescência com $\lambda_{\text {exc }}=560$ para os extratos de folhas de laranjeira Pêra com porta-enxerto de limão Cleópatra: a) sadia, b) Declínio, c) Greening assintomática. . .67

Figura 5.5 - Espectro típico de emissão de folhas de laranja Hamlin com porta-enxerto de limão Cravo, obtidos no sistema portátil de espectroscopia de fluorescência induzida por laser (FIL) desenvolvido e construído no LOLEIA. .. .70

Figura 5.6 - Gráfico de PCA gerado através dos espectros de laranja Hamlin com porta-enxerto de limão Cravo contaminados com MSC, Declínio e plantas sadias, obtidos no sistema portátil de espectroscopia de fluorescência induzida por laser (FIL) desenvolvido e construído no LOLEIA71

Figura 5.8 - Gráfico de PCA gerado através dos espectros de emissão de fluorescência de folhas de laranjeira Hamlin em porta-enxerto de limão Cravo coletada na estação de chuva, obtidos no sistema portátil de FIL desenvolvido e construído no LOLEIA em plantas contaminadas com GA, GS, MSC, Declínio e plantas sadias. . .73 
Figura 5.9 - Espectro típico de emissão de fluorescência de folhas de laranjeira Valência com em porta-enxerto de limão Cravo coletadas em época de seca, obtidos através do sistema portátil de FIL desenvolvido e construído no LOLEIA.

Figura 5.10 - Gráfico de PCA gerado através dos espectros de emissão de fluorescência de folhas de laranjeira Valencia em porta-enxerto de limão Cravo coletadas em época de seca, obtido através do sistema portátil de FIL desenvolvido e construído no LOLEIA em plantas contaminadas com MSC, Declínio e plantas sadias. .76

Figura 5.11 - Espectros típicos de emissão de folhas de laranjeira Valência em porta-enxerto de limão Cravo coletadas em estação chuvosa, obtidos através do sistema portátil FIL desenvolvido e construído no LOLEIA.

Figura 5.12 - Gráfico de PCA gerado através dos espectros de folhas de laranjeira Valência em porta-enxerto de limão Cravo coletadas em estação chuvosa, obtido através do sistema portátil FIL desenvolvido e construído no LOLEIA em plantas contaminadas com GA, GS, MSC,

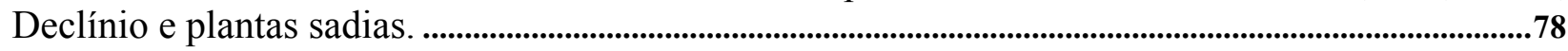

Figura 5.13 - Espectro típico de emissão de fluorescência de folhas de laranjeira Pêra em portaenxerto de limão Cravo coletadas em estação de seca, obtido através sistema portátil desenvolvido e construído no LOLEIA.

Figura 5.14 - Gráfico de PCA gerado através dos espectros de folhas de laranjeira Pêra em portaenxerto de limão Cravo coletadas em estação de seca, obtido através do sistema portátil FIL desenvolvido e construído no LOLEIA em plantas contaminadas com MSC, Declínio e plantas sadias.

Figura 5.15 - Espectro típico de emissão de fluorescência de folhas de laranjeira Pêra em portaenxerto de limão Cravo coletadas em estação chuvosa, obtido através sistema portátil desenvolvido e construído no LOLEIA.

Figura 5.16 - Gráfico de PCA gerado através dos espectros de folhas de laranjeira Pêra em portaenxerto de limão Cravo coletadas em estação de chuva, obtido através do sistema portátil FIL desenvolvido e construído no LOLEIA em plantas contaminadas com GA, GS, MSC, Declínio e plantas sadias.

Figura 5.17 - Espectro típico de emissão de fluorescência de folhas de laranja Pêra em portaenxerto de tangerina Sunki em plantas irrigadas, obtidos através do sistema portátil de FIL desenvolvido e construído no LOLEIA.

Figura 5.18 - Gráfico de PCA gerado através dos espectros de emissão de fluorescência de folhas de laranjeira Pêra em porta-enxerto de tangerina Sunki em plantas irrigadas, obtidos através do sistema portátil de FIL desenvolvido e construído no LOLEIA em plantas contaminadas com GA, GS e plantas sadias.

Figura 5.19 - Espectro típico de emissão de fluorescência de folhas de laranjeira Natal em portaenxerto de limão Cravo coletadas em estação chuvosa, obtido através sistema portátil desenvolvido e construído no LOLEIA. 
Figura 5.20 - Gráfico de PCA gerado através dos espectros de folhas de laranjeira Natal em portaenxerto de limão Cravo coletadas em estação de chuva, obtido através do sistema portátil FIL desenvolvido e construído no LOLEIA em plantas contaminadas com MSC1, MSC2, Declínio e plantas sadias .86

Figura 5.22 - Gráfico de PCA gerado através dos espectros de emissão de fluorescência de folhas de laranjeira Natal em porta-enxerto de Poncirus Trifoliata em plantas irrigadas, obtidos através do sistema portátil de FIL desenvolvido e construído no LOLEIA em plantas contaminadas com GA e plantas sadias. .88

Figura 5.23 - Gráfico de PCA gerado através dos espectros de emissão de fluorescência de folhas de laranjeira Natal em porta-enxerto de Citromelo Swingle em plantas irrigadas, obtidos através do sistema portátil de FIL desenvolvido e construído no LOLEIA em plantas contaminadas com GA, GS, Amarelecimento e plantas sadias. 


\section{LISTA DE ABREVIATURAS E SIGLAS}

\begin{tabular}{|c|c|}
\hline$\%$ & Porcentagem \\
\hline Clorof a & Clorofila a \\
\hline Clorof b & Clorofila $b$ \\
\hline CTV & Vírus da Tristeza do Citros \\
\hline $\mathrm{CVC}$ & Clorose Variegada dos Citros \\
\hline FIL & Fluorescência Induzida por Laser \\
\hline GA & Greening Assintomática \\
\hline GS & Greening Sintomática \\
\hline HLB & Huanglongbing \\
\hline LOLEIA & Laboratório de Óptica e Laser da Embrapa Instrumentação Agropecuária \\
\hline $\operatorname{mim}$ & Minuto \\
\hline $\mathrm{ms}$ & Milisegundo \\
\hline MSC & Morte Súbita dos Citros \\
\hline MSC1 & Morte Súbita dos Citros com Sintomas \\
\hline MSC2 & Morte Súbita dos Citros com Sintomas Avançados \\
\hline $\mathrm{mW}$ & MiliWattas \\
\hline $\mathrm{nm}$ & Nanômetro \\
\hline $\mathrm{nm} / \mathrm{mim}$ & Nanômetro por minuto \\
\hline PC1 & Primeira Componente Principal \\
\hline PC2 & Segunda Componente Principal \\
\hline PC3 & Terceira Componente Principal \\
\hline PCA & Análise de Componentes Principais \\
\hline PCR & Reação da Polimerase em Cadeia \\
\hline u.a & Unidade Arbitrária \\
\hline$\lambda$ & Comprimento de Onda \\
\hline
\end{tabular}




\section{ABSTRACT}

Currently the largest portion of money applied to citriculture focus on health of the orchard. The phytosanitary costs, along with fertilizers, exceed $60 \%$ of the production cost. The control of diseases such as Sudden Death of Citrus (SDC), Decline and Greening, also known as Huanglongbing, is done by visual inspection, which confers to the method a high level of subjectivity and imprecision.

This work was intended to develop a quick and safe methodology of diagnosis for the diseases mentioned above using fluorescence spectroscopy and laser-induced fluorescence (LIF). It was used in this study two rootstocks, Cravo and Cleopatra, and four varieties of crown: Pera, Natal, Valencia and Hamlin. The diseases studied were also classified into different levels of severity. The index 1 was used for low severity SDC, and 2 for a more advanced stage of this disease. For Greening has been made a distinction between symptomatic and asymptomatic leaves. The Decline of Citrus disease was also part of this study because its symptoms are very similar to those in the initial phase of SDC, and this is a serious problem for the evaluation of contamination in the field.

Initially, studies have been made on the fluorescence of photosynthetic pigments from the extracts of ill and healthy leaves using a non-portable fluorimeter. For the leaf analyses we used a portable system of laser-induced fluorescence spectroscopy developed in LOLEIA.

The study of extracts revealed that the largest cariations occur in the concentrations of chlorophyll a and $\mathrm{b}$, and that acessory pigments like $\alpha$ and $\beta$-carotones do not fluoresce in the wavelength used. In general, it is possible to say that ill plants have a decrease of chlorophylls a e b. The leaf results were analyzed through the statistical method Principal Component Analysis (PCA) in order to facilitate the observation of spectral changes. Through the developed 
methodology it was possible to identify and distinguish the diseases with efficiency greater than 93\%. However, these results contributed for the development of a methodology for diagnosis of citrus diseases in a quick, accurate and economically viable way. 


\section{RESUMO}

Atualmente os maiores gastos da citricultura concentram-se em manter a sanidade do pomar. Os custos com defensivos agrícolas e outros manejos, ultrapassam $60 \%$ do custo da produção. O diagnóstico de doenças como a Morte Súbita dos Citros (MSC), Declínio e o Greening, também conhecida como Huanglongbing, são feitos de forma visual, os que conferem ao método um elevado grau de subjetividade e imprecisão.

O presente trabalho teve por finalidade desenvolver uma metodologia rápida e segura de diagnóstico para as doenças acima citadas utilizando espectroscopia de fluorescência e fluorescência induzida por laser (FIL). Foram utilizados neste estudo cinco porta-enxertos, Limoeiro Cravo, Tangerina Cleópatra, Tangerina Sunki, Poncirus Trifoliata e Citrumelo Swingle e quatro variedades de copa de laranja doce, Pêra, Natal, Valência e Hamlin. As doenças estudadas também foram classificadas em diferentes níveis de severidade. O índice 1 foi utilizado para baixa severidade da MSC, e 2 para o estágio mais avançado da doença. Para o Greening fezse uma distinção entre folhas sintomáticas e assintomáticas. A doença, Declínio dos Citros, também fez parte deste estudo em função dos sintomas serem muito parecidos aos da fase inicial de MSC, sendo este um problema sério para as avaliações de contaminação no campo.

Inicialmente, foram realizados estudos a respeito da emissão de fluorescência dos pigmentos fotossintéticos provenientes dos extratos de folhas doentes e sadias através de um fluorímetro de bancada. Para as análises foliares utilizou-se um sistema portátil de espectroscopia de

fluorescência induzida por laser desenvolvido no LOLEIA (Laboratório de Óptica e Laser da Embrapa Instrumentação Agropecuária). 
O estudo dos extratos revelaram que as maiores variações ocorrem nas concentrações de clorofila a e b e que os pigmentos acessórios como $\alpha$ e $\beta$ - carotenos não fluorescem no comprimento de onda estudado. De uma maneira geral, é possível dizer que plantas doentes sofrem uma diminuição das clorofilas a e b. Os resultados dos espectros das folhas foram analisados por um método estatístico de Análises de Componentes Principais (PCA) para facilitar a observação das alterações espectrais. Através da metodologia desenvolvida foi possível a identificação e a distinção entre plantas doentes e sadias com nível de acerto superior a 93\%. Contudo, estes resultados contribuíram para o desenvolvimento de uma metodologia para diagnóstico das doenças de citros de uma forma rápida, precisa e economicamente viável. 


\section{CAPÍTULO 1 INTRODUÇÃO}

O Brasil, desde o início da década de 90, mantém-se como o maior produtor mundial de laranja, sendo responsável por $80 \%$ do comércio internacional de suco de laranja concentrado e congelado. Para essa produção, avaliada em US\$ 900 milhões, gastam-se cerca de US\$ 410 milhões de insumos, movimentando aproximadamente US\$1,5 bilhões com a venda de produtos citrícolas, entre sucos e frutas frescas (FNP Consultoria \& Comércio, 2002). O segundo maior produtor são os Estados Unidos, seguido do México, China e Espanha. A Espanha e os Estados Unidos são os principais exportadores de frutas frescas, o que corresponde respectivamente a $38 \mathrm{e}$ 18\% das exportações mundiais (Boteon, 2002).

O Estado de São Paulo tem cerca de 34,2 milhões de plantas em formação e 163,5 milhões de plantas cítricas em produção, respondendo por mais de $80 \%$ da produção nacional de frutos cítricos. Atualmente, é responsável por 97\% das exportações brasileiras, sendo o grande núcleo dinâmico do complexo citrícola brasileiro. Este mercado destina cerca de US\$ 1,5 bilhão de divisas para o país, Estado e municípios e emprega 400 mil pessoas. O parque citrícola paulista, juntamente com o triângulo mineiro, conta com 198 milhões de árvores. A colheita de laranja faz-se durante todo o ano devido a composição das variedades como Hamlin, Lima, Pêra, Seleta, Bahia, Natal, Valência e Folha Murcha. Destas algumas são próprias para a produção de suco, como a Pêra que representa 38\% do total de árvores, seguida de Valência, Natal e Hamlin, com respectivamente 17, 25 e 7\% (Boteon, 2002).

Com o avanço da tecnologia no campo, as plantas passaram a ser multiplicadas por enxertia, o que trouxe grandes vantagens em termos de precocidade e uniformidades dos pomares. Porém, ao mesmo tempo diminuiu a variabilidade, tornando a cultura um alvo constante 
de inúmeras pragas e doenças que, encontrando condições favoráveis ao seu desenvolvimento, são capazes de causar danos irreversíveis. Os custos fitossanitários, junto com os fertilizantes, ultrapassam $60 \%$ do custo da produção. A qualidade e a quantidade das frutas cítricas são freqüentemente ameaçadas devido aos danos deixados na planta, que dependendo da intensidade do ataque, podem torná-la improdutiva ou levar à sua erradicação.

Em meados de 2004 foi relatada uma nova doença nos pomares paulistas. Uma doença devastadora e sem cura, originária da Ásia e África. Huanglongbing (HLB), também conhecida como Greening, hoje é a doença mais temida entre os produtores de laranja por não possuir cura nem tratamento, por ter um alto poder de disseminação e afetar todas as variedades comerciais de laranjeiras. As plantas devem ser arrancadas imediatamente, assim que se confirmar o diagnóstico positivo da doença.

O Greening tem como agente causal uma bactéria que habita o floema da planta hospedeira sendo conhecida como Candidatus Liberibacter onde há três espécies, Candidatus Liberibacter africanus, Candidatus Liberibacter asiaticus e o principal agente causal no Estado de São Paulo é o Candidatus Liberibacter asiaticus. Os sintomas do Greening são virtualmente os mesmos, independente de onde ocorre à doença, seja na América, Ásia ou África. Galhos, folhas e frutos são afetados pela doença. Inicialmente os sintomas aparecem nos galhos, que se destacam pela cor amarelada em contraste com a coloração verde das folhas dos ramos não afetados. As folhas apresentam coloração amarela pálida, com áreas verdes, formando manchas irregulares e assimétricas (mosqueadas). O fruto fica deformado e assimétrico. A parte branca da casca, em alguns casos, apresenta uma espessura maior que o normal. Também ocorre redução no tamanho dos frutos e intensa queda. 
Por não possuir cura, o Greening é hoje a doença mais temida dos últimos tempos na citricultura. Ela já foi responsável pelo arranquio de mais de 3 milhões de plantas e a grande maioria delas em época de maior produtividade.

Outra doença importante do parque citrícola brasileiro é a MSC. Essa doença ficou assim conhecida por ter capacidade de definhar e matar as plantas sobre limoeiros Cravos. A MSC, cujo agente causal permanece desconhecido, desde 1999 já causou o definhamento e morte de mais de 4 milhões de árvores de laranjeira doce enxertadas sobre limoeiro Cravo, na região do sul do Triângulo Mineiro e norte e noroeste do Estado de São Paulo, por onde têm se disseminado rapidamente para novos talhões, propriedades e municípios. A baixa variabilidade genética das copas e porta-enxertos utilizados na citricultura e a falta de descontinuidade espacial e temporal de pomares de citros no Estado de São Paulo, aliadas à rapidez de disseminação da doença e perda da viabilidade econômica das plantas afetadas, torna a MSC uma séria ameaça para a citricultura paulista e nacional. Além dos prejuízos causados pela redução da produção e morte das plantas afetadas, o controle da doença provavelmente acarretará maiores custos e adaptações no sistema de manejo de pomares subenxertados ou com outros porta-enxertos, cuja irrigação será muitas vezes necessária. A morte súbita dos citros provoca diminuição no tamanho, peso e quantidade de frutos, mas os mesmos podem ser consumidos sem problema algum, pois não oferecem risco à saúde.

A doença tem causado grandes preocupações, pois cerca de $85 \%$ da citricultura está instalada com o porta-enxerto de Limão Cravo e isto poderá levar a grandes prejuízos econômicos e causar alguns impactos de cunho social como desemprego.

Contudo, o objetivo do presente trabalho foi desenvolver uma metodologia de diagnóstico rápida, precisa e não invasivo para diagnosticar a MSC e Greening, visto que hoje a identificação 
prática dessas doenças é feita de forma visual e bastante subjetiva. Para tanto, a metodologia utilizada foi um sistema portátil de espectroscopia de fluorescência induzida por laser (FIL).

Finalmente, os resultados assim obtidos visam contribuir com os produtores de laranja facilitando o diagnóstico da MSC e o Greening em seus pomares através de um método científico e confiável. 
CAPÍTULO 2

\section{REVISÃO BIBLIOGRÁFICA}

\subsection{MORTE SÚBITA DO CITROS (MSC)}

A morte súbita dos citros (MSC) é uma nova e extremamente destrutiva doença dos citros, cuja etiologia, bem como seus possíveis vetores e controles, ainda não são bem conhecidos. $\mathrm{O}$ nome é atribuído a essa doença pela rápida velocidade com que as plantas afetadas morrem. Todo o quadro sintomatológico da MSC pode ocorrer rapidamente, de um a mais de 12 meses, dependendo da época do ano e da variedade (Informativo Centro de Citricultura, 2001).

A MSC foi descrita pela primeira vez no início de 2001, em Comendador Gomes, sul do Triângulo Mineiro (Gimenes-Fernandes e Bassanezi, 2001). As primeiras observações da doença foram feitas em laranja Valência enxertada sobre limoeiro Cravo(Citrus limonina). Posteriormente, a mesma doença em outras variedades (Hamlin, Natal, Westin, Pêra, Rubi, e tangerias Cravo e Ponkan enxertada sobre limoeiro Cravo e Volkameriano).

A MSC está associada à combinação entre laranjeira doce sobre limoeiro 'Cravo', uma vez que combinações entre laranjeiras doces sobre porta-enxertos de tangerinas 'Cleópatra' (C. reshni Hort. Ex Tan.) e 'Sunki' (C.sunki Hort. Ex Tanaka), Poncirus trifoliata (L.) Raf. E citrumelo'Swingle' [P. trifoliata(L.) Raf. X C. paradisi Macf.] até então não apresentaram sintomas da doença (Gimenes-Fernandes et al.,2002).

A MSC é uma das doenças muito importantes na citricultura brasileira, uma vez que os limoeiros 'Cravo' e 'Volkameriano' representam mais de $85 \%$ dos porta-enxertos utilizados em todo parque citrícola brasileiro, sendo, portanto, uma das maiores ameaças à competitividade do agronegócio citrícola. 


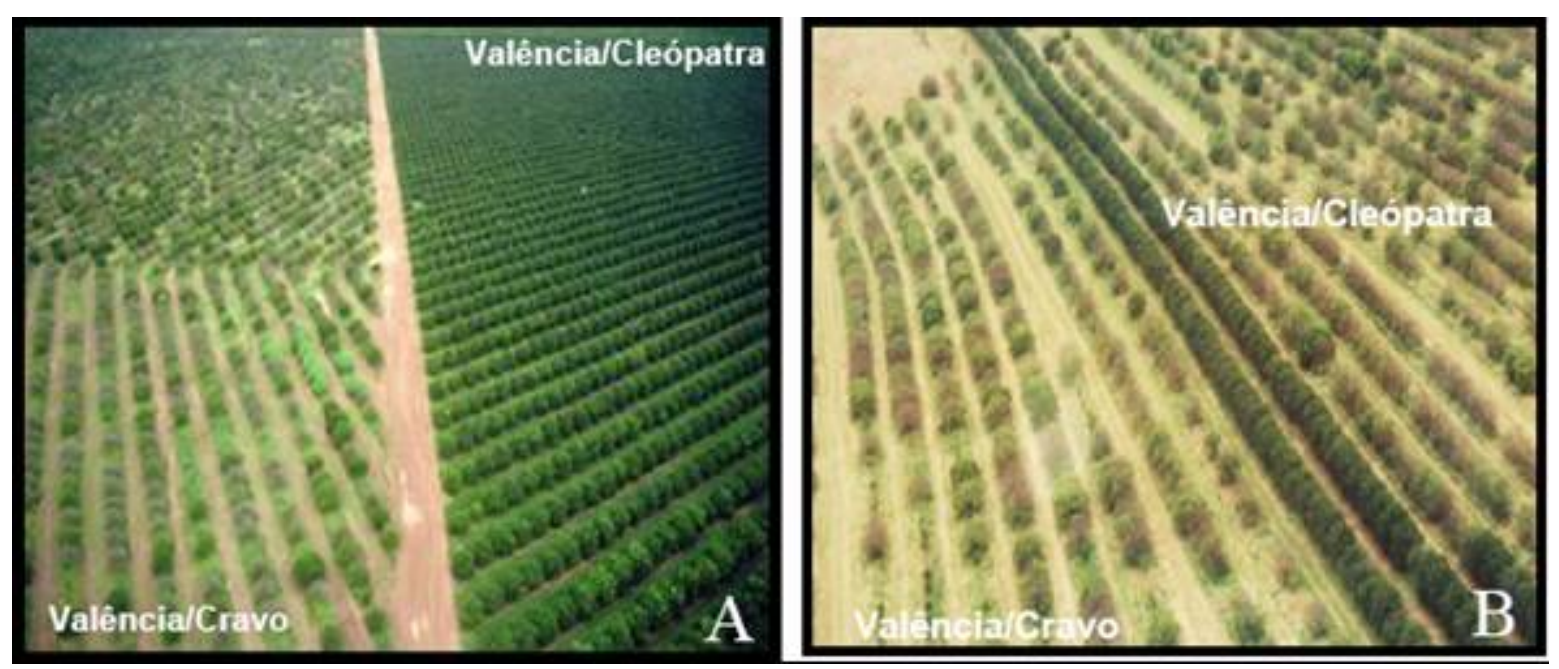

Figura 2.1- Vista aérea de plantios de laranjeiras doce 'Valência' enxertada com limoeiro cravo, apresentando sintomas de MSC, e de laranjeira-doce 'Valência' enxertada com tangerina 'Cleópatra', sadia (A). Em (B) verifica-se duas linhas de plantio de laranjeira-doce 'Valência' enxertada em tangerina 'Cleópatra', sem sintomas da doença em meio de um plantio de laranjeira-doce 'Valência' enxertada em limoeiro 'Cravo', totalmente afetado pela doença. Fonte: Fundecitrus.

\subsubsection{SINTOMAS DA MORTE SÚBITA DOS CITROS}

As plantas afetadas pela MSC apresentam sintomas de definhamento generalizado. Inicialmente, toda a copa da planta afetada apresenta folhas sem brilho e de coloração verde pálida (Figura 2.2). Posteriormente, ocorre desfolha parcial, produto de poucas brotações e ausência de brotação interna, fato que se acentua com a evolução da doença. 


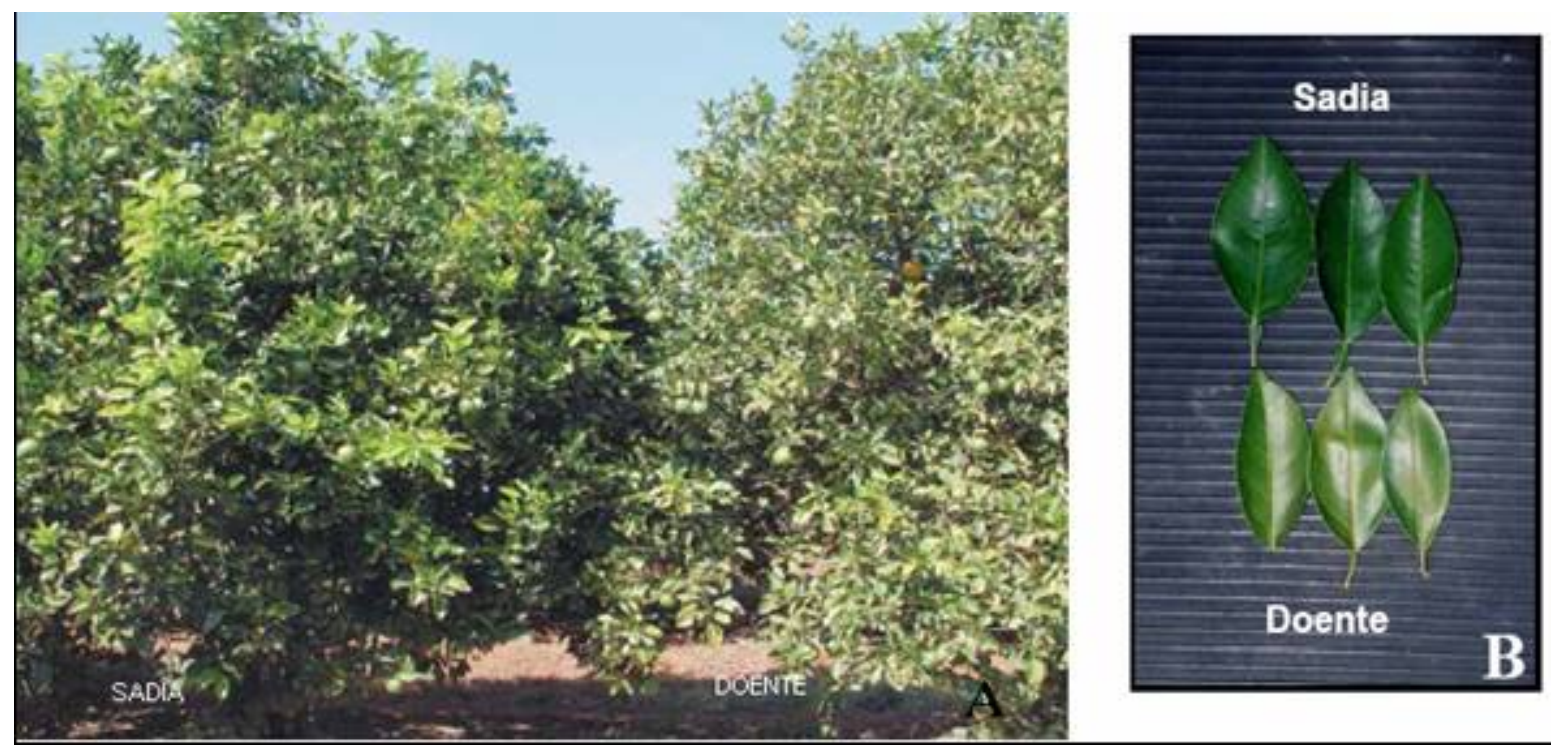

Figura 2.2 - Laranjeiras com sintomas da MSC mostrando perda de brilho generalizada e coloração verde-pálida das folhas, contrastando com a cor normal das plantas sadias (A) e folhas coletadas em plantas sadias e doentes, mostrando o contraste de coloração entre as mesmas (B). Fonte: Fundecitrus

O sistema radicular apresenta poucas radicelas e muitas raízes podres e mortas. O principal sintoma dessa doença precede a morte das raízes e o quadro sintomatológico da copa. Ele se caracteriza por uma coloração entre amarelo e alaranjado presente nos tecidos internos da casca do porta-enxerto, na região do floema funcional, abaixo da região de enxertia até as raízes mais grossas, em contraste com a cor creme dos tecidos da casca da copa (Figura 2.3) (Jesus Junior et al., 2003). Essas regiões de tecido amarelado correspondem a vasos do floema que se encontram obstruídos e degenerados (Gimenes-Fernandes \& Bassanezi, 2001). 


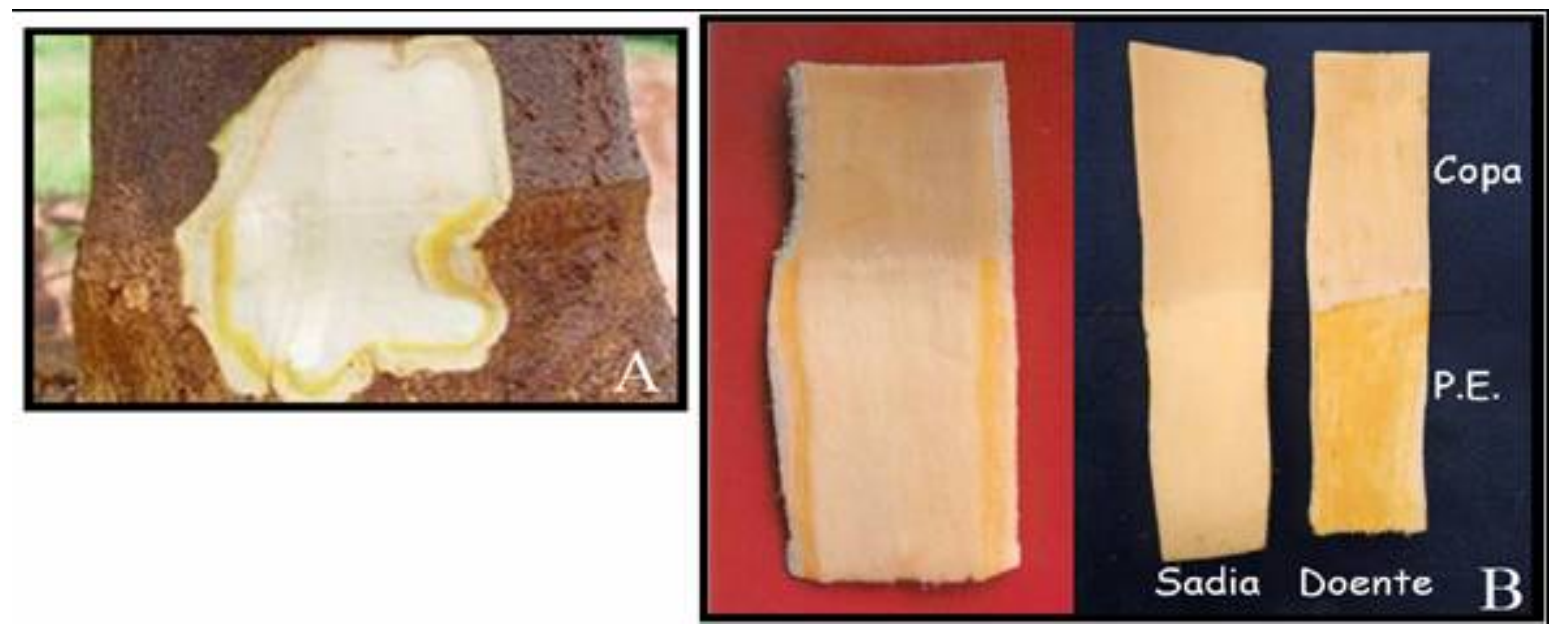

Figura 2.3 - Coloração amarelada nos tecidos internos da casca do porta-enxerto limão 'Cravo', contratando com os tecidos brancos da copa (A) e comparação da coloração citada em (A) entre plantas sadias e doentes (B), mostrando que esse sintoma é típico de plantas com morte súbita dos citros. Fonte: Fundecitrus.

Esses sintomas se manifestam à medida que a doença se desenvolve e culmina com a morte da planta. O aparecimento dos sintomas e a morte da planta ocorrem quando a necessidade de absorção de água para os novos brotos e para a maturação dos frutos se torna alta. As raízes das laranjeiras afetadas apresentam morte de uma grande porção do sistema radicular, progredindo da ponta da raiz para a base, até que a raiz principal seja afetada e morra (Figura 2.4). 


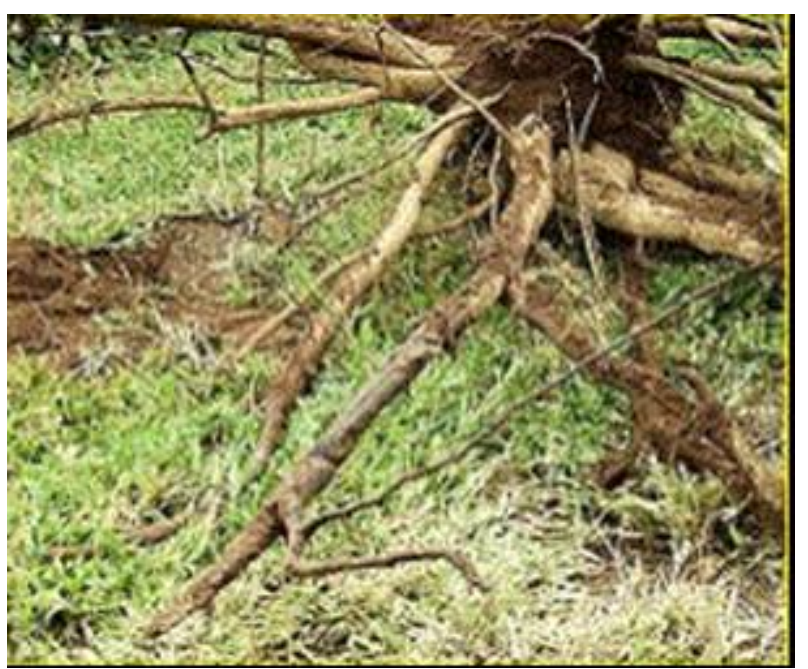

Figura 2.4 -Detalhe do sistema radicular da planta com sintoma inicial de MSC, o qual apresenta grande quantidade de raízes mortas, geralmente com poucas radicelas. Fonte: Fundecitrus

A produção das plantas que não entram em colapso repentino vai diminuindo gradativamente até a morte dessas plantas, sendo que quanto mais severos os sintomas da doença, maiores são as diferenças de peso, número e tamanho de frutos colhidos. Plantas com sintomas iniciais de MSC apresentam uma produção, em média, 27,59\% menores que plantas sadias em peso total de fruto por plantas, $11,64 \%$ em número de frutos total por planta e 21,56\% em tamanho de fruto. Plantas que apresentam alta severidade da doença reduzem, em média, 50,41\% do peso total do fruto por planta, $25,64 \%$ do número total do fruto por planta e $40,67 \%$ do tamanho do fruto em relação às plantas sadias (Bassanezi et al., 2005). Entretanto, em alguns casos, tem sido observada rápida mortalidade da planta após ter ocorrido uma grande produção, cujos frutos, nesses casos, são normais em número, peso e tamanho e não se desprendem da planta com a morte da laranjeira, devido à rapidez que ocorre o colapso.

Todos esses sintomas podem aparecer rapidamente, no prazo de 12 meses, dependendo da época do ano, (mais rápido na primavera) e da condição de produção da planta (Bassanezi et al., 2002; Muller et al., 2002). Atualmente, nenhuma planta com menos de 22 meses, em pomares de 
região de incidência da MSC, apresentou sintomas. A análise de talhões em diferentes idades, nos quais a doença está apenas no início, permitiu deduzir que o período de inoculação seja de dois ou três anos, dados confirmados pelos testes de transmissão por enxertia (Yamamoto et al., 2004). A partir desses dados, pode-se concluir que o período de incubação da MSC deve ser de pelo menos de 2 anos em plantas jovens, e que as plantas que atualmente apresentam sintomas da MSC foram infectadas há certo tempo.

\subsubsection{O PORTA-ENXERTO LIMOEIRO CRAVO}

O conhecimento de diferenças e o uso consciente dos porta-enxertos permitem maior produtividade, tanto na produção quanto na dos maturação dos frutos. O uso do porta-enxerto induz na copa alterações no seu crescimento, tamanho, precocidade de produção, produtividade, época maturação e massa dos frutos, permanência dos frutos nas plantas, conservação da fruta após a colheita, transpiração das folhas, fertilidade do pólem, composição química das folhas, capacidade de absorção, síntese e utilização de nutrientes, tolerância e salinidade, resistência a seca a e ao frio, resistência e tolerância a pragas e doenças( Pompeu Júnior, 1991).

A maior parte da citricultura brasileira baseia- se em um único porta-enxerto, o limoeiro Cravo. Este fato se deve a algumas características vantajosas deste material, tais como rusticidade, precocidade, produtividade e principalmente resistência às condições de seca. Esta última característica é importante, já que permite o plantio sem irrigação, reduzindo bastante o custo de produção, o que torna competitiva a nossa citricultura no mercado internacional.

A decisão de se substituir o porta-enxerto limoeiro Cravo por algum outro porta-enxerto deve considerar a inviabilidade da citricultura em locais onde não há disponibilidade de água para 
a irrigação, pois os porta-enxertos tolerantes a MSC apresentam baixa produção em sistemas de plantio sem suprimento de água (Jesus Júnior et al., 2003).

\subsubsection{DISTRIBUIÇÃO DA DOENÇA}

Desde sua constatação, os processos de disseminação da MSC em pomares afetados são bastante rápidos, podendo atingir de $30 \%$ a $70 \%$ das plantas em apenas seis meses (Bassanezi et al., 2002; 2003a; 2003b).

Entre setembro de 2002 e dezembro de 2003, os números de plantas com sintomas de MSC encontradas no campo, no Estado de São Paulo, passaram de 22,1 mil para 44,4 mil, e outras 392,2 mil plantas foram erradicadas pela doença no mesmo período (Fundecitrus, 2004).

Os números de plantas sintomáticas têm aumentado muito desde a primeira observação da doença até os dias de hoje. De 500 plantas infectadas inicialmente, estima-se que esse valor esteja hoje em dia em mais de 2 milhões de plantas (Fundecitrus, 2004). De dezembro de 2001 a dezembro de 2003, a doença passou de sete município (Libanore et al., 2002) para 30 municípios (Fundecitrus, 2004) (Figura 6), atingindo municípios de Minas Gerais (Campo Florido, Comendador Gomes, Conceição das Alagoas, Fronteira, Frutal, Itaituba Monte Alegre de Minas, Planura, Prata, São Francisco de Sales, Uberaba e Uberlândia) e municípios do norte e noroeste do Estado de São Paulo (Altair, Bálsamo, Barretos, Bebedouro, Cajobi, Colômbia, Cosmorama, Embaúba, Guaraci, Ibirá, Ipiguá, Monte Azul Paulista, Nova Granada, Olímpia, Onda Verde, Paulo de Faria, Riolândia e Tanabi) (Fundecitrus, 2006). 


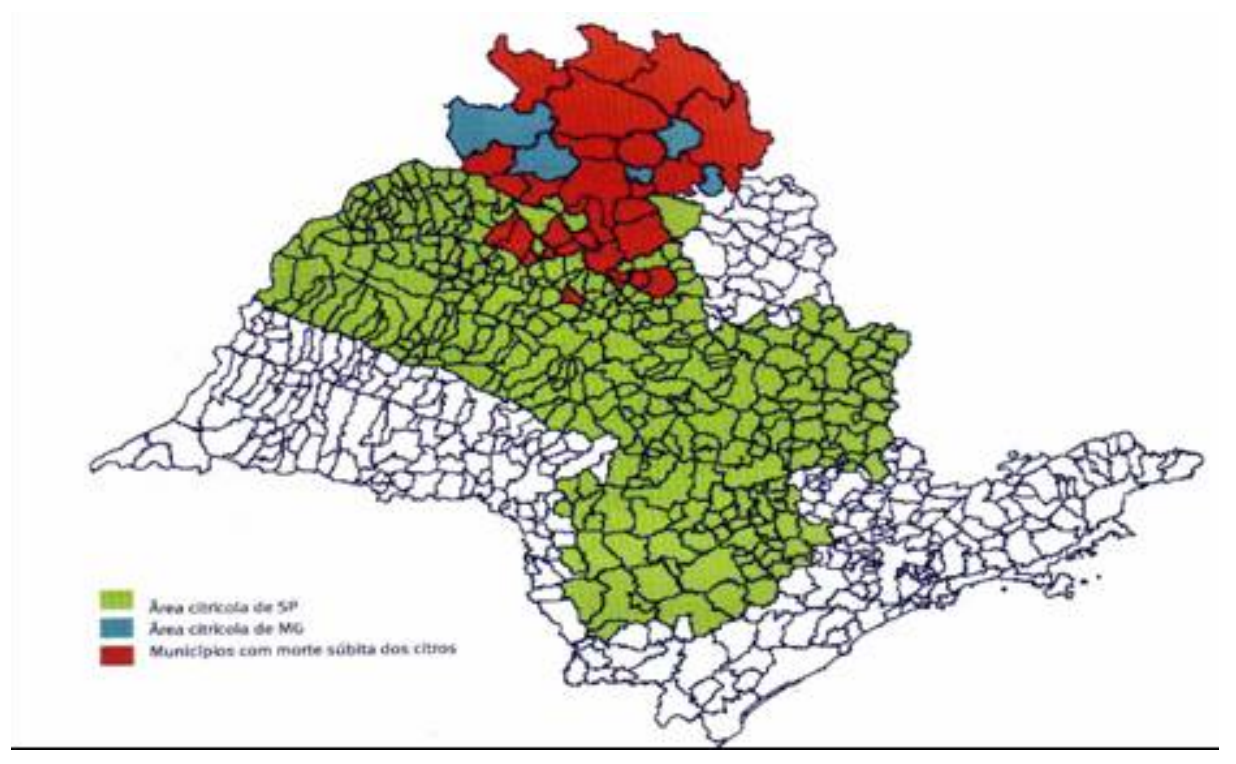

Figura 2.5 - Mapa da distribuição da morte súbita dos citros em SP e MG. Fonte: Jesus Junior et al., 2004b.

\subsubsection{ETIOLOGIA}

Com base nos resultados de estudos da evolução e da distribuição da MSC concluiu-se que a doença é infecciosa, o agente causal possui um vetor alado envolvido na sua disseminação (Bassanezi et al., 2003), e a disseminação é bastante rápida e eficiente (Jesus Junior e Bassanezi, 2004a). No entanto, a MSC é uma doença de etiologia ainda desconhecida.

Foi comprovado que a causa primária da MSC é de natureza biótica, pois foi verificado experimentalmente que a doença pode ser transmitida de uma planta doente para uma planta sadia através da inoculação por enxertia de borbulhas sob condições de ausência de insetos (Yamamoto et al., 2003). Este trabalho permite excluir como causa da doença os fatores abióticos, pragas e nematóides e fungos de solo, os quais não são transmitidos por enxertia. Assim, agentes que podem ser transmitidos desta maneira são viróides, vírus ou bactérias endógenas (restritas ao xilema e floema). 
Por ser o quadro sintomático da MSC resultante de alterações no sistema vascular da planta, as buscas por bactérias e fitoplasmas que habitam e colonizam os vasos da planta foram realizadas intensivamente, principalmente em relação ao Canditatus Liberibacter asiaticus, Candidatus Liberibacter africanus e Candidatus Liberibacter americanus, causadores do Huanglongbing (Greening), Spiroplasma citri, causador do stubborn e Xylella fastidiosa, causadora da variegada dos citros (CVC). Os testes de diagnóstico por Reação em Cadeia da Polimerase (PCR) em diferentes laboratórios do Brasil e do exterior não constataram a presença desses organismos em tecidos da casca do tronco e raiz de plantas doentes (I.P.BedendoESALQ/USP; M.A. Machado-APTA Citros; J.Hartung-USDA/Estados Unidos; M.GarnierINRA/França - dados não publicados)

Excluindo fatores abióticos, pragas, nematóides, fungos, bactérias habitantes do xilema e do floema e viróides como possíveis agentes causais da MSC, a hipótese mais provável é que a MSC seja causada por um vírus.

Atualmente existem duas hipóteses quanto ao possível vírus causador desta doença. Os estudos têm apontado para o envolvimento do vírus da tristeza dos citros (CTV, família Closteroviridae, gênero Closterovirus) ou um vírus da família Tymoviridae, recentemente detectado em plantas doentes (Harakava, 2004; Barros et al., 2004; Maccheroni et al., 2005). Não se pode descartar, porém, as hipóteses sem estudos.

A primeira hipótese é que a MSC seja causada por uma estirpe mais virulenta do CTV, dada à semelhança da MSC a tristeza na sua forma de Declínio rápido (Bové et al., 2002) que entre 1939 a 1949 destruiu 90\% das laranjeiras existentes em São Paulo (Kimati et al.,1980). Essa hipótese se baseia em várias evidências, como a semelhança entre ambas as doenças em relação ao aspecto temporal na presença do pulgão preto (Toxoptera citricida) (Bassanezi et al., 2003; Jesus Junior et al., 2004a), associação constante de plantas com sintomas de MSC com o CTV e 
as semelhanças entre a MSC e a Tristeza quanto à sintomatologia (Gimenes-Fernades et al., 2001; Muller et al., 2002) cuja remissão dos sintomas pode ser obtida com a utilização da subenxertia.

Além disso, somente CTV foi encontrado por microscopia eletrônica (E.W.Kitajima, dados não publicados), detectado por teste sorológico (J.A.M. Rezende, M.A. Machado e M.Cambra, dados não publicados) e através de padrões de RNA dupla fita ( P. Moreno, dados não publicados) em todas as amostras examinadas (Bassanezi et al., 2002). Entretanto, até o momento nenhuma associação entre a CTV e a MSC foi comprovada experimentalmente (Derrick et al., 2003; Targon et al., 2004), visto que o CTV está presente tanto nas plantas como sintomas da MSC, quanto em plantas assintomáticas.

A segunda hipótese é que a MSC seja causada por um outro vírus que não o CTV, mas algum novo vírus da família Tymoviridae. Esta hipótese está baseada no fato de seqüências de RNA com semelhança com vírus de RNA da família Tymoviridae têm sido detectadas em plantas afetadas pela MSC, mas não em árvores de região não infectadas pela MSC (Reinach, 2003; Haraakava, 2004; Barros et al., 2004).

\subsubsection{MANEJO DA DOENÇA}

Não é correto efetuar recomendações para manejo ou prevenção de doença cuja etiologia ainda não esteja cientificamente comprovada, conforme foi visto no item anterior. As estratégias recomendadas são baseadas no que foi observado em campo. Dentre as medidas recomendadas, tem-se:

1) Não transportar mudas, borbulhas e cavalinhos das regiões com a doença para aquelas que onde a doença ainda não foi constatada;

2) Evitar o plantio de limoeiro Cravo e Volkameriano; 
3) Diversificação do uso de porta-enxertos tolerantes;

4) Subenxertia com porta-enxerto tido como tolerantes (tangerina Cleópatra e Sunki ou citromeleiro Swingle em árvores sobre limoeiro Cravo ou Volkameriano). O subenxerto deve ser feito o mais cedo possível (Figura 2.6).

A subenxertia é uma técnica que consiste na substituição do porta-enxerto e cria um sistema radicular suplementar para alimentar a planta doente. Essa técnica pode ser adotada para recuperar árvores doentes em pomares contaminados, desde que os sintomas não estejam em um estágio avançado e a recuperação da mesma varia com o estágio da doença, estas em um estágio inicial podem se recuperar em até 2 anos. Esta técnica é recomendada para pomares com menos de 10 anos e em boas condições sanitárias e deve ser feita em períodos chuvosos.

Os porta-exertos tolerante a MSC são sensíveis ao déficit hídrico e, portanto, necessitam de irrigação.

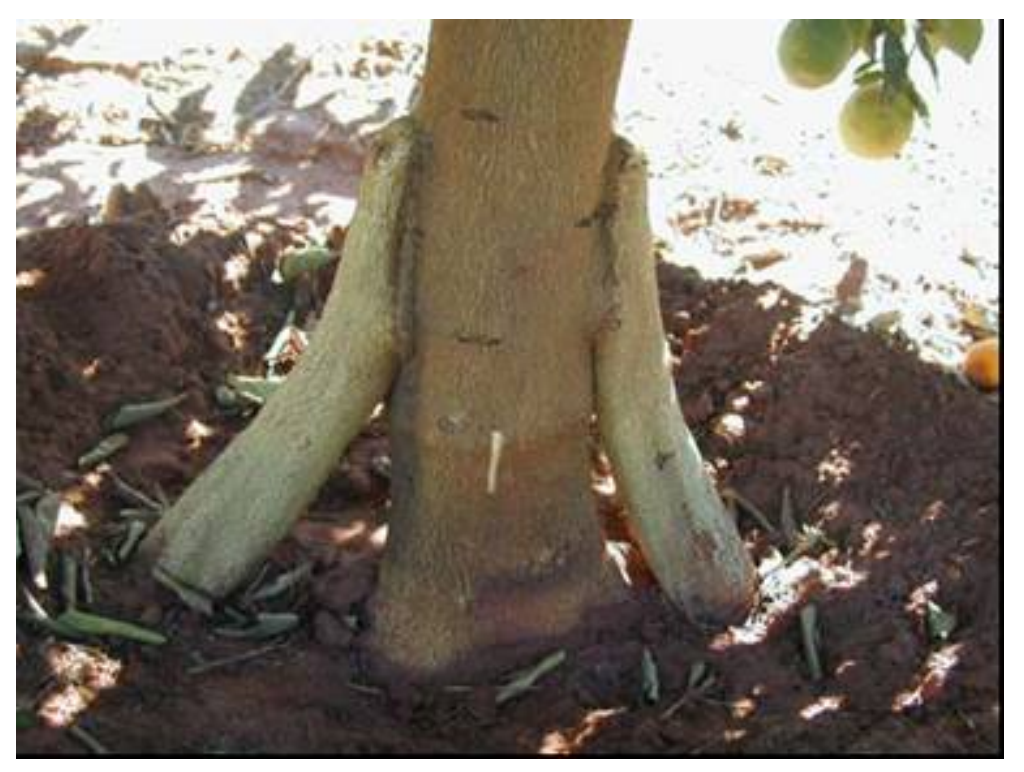

Figura 2.6 - Subenxertia realizada em planta com seis anos de idade através da técnica do $\mathrm{T}$ invertido, utilizando-se dois cavalinhos. Fonte: Fundecitrus. 


\subsection{HUANGLONGBING OU GREENING}

Huanglongbing (HLB), também chamada de Greening é uma doença destrutiva de citros, que apresenta uma grande ameaça para a indústria citrícola do mundo e esta invadindo novas áreas de cultivo de citros (Bové, 2006a). Huanglongbing significa "doença do ramo amarelo", ou “doença do dragão amarelo" em Chinês, e foi relatada primeiramente no Sul da China em 1919. É reconhecida por ocorrer em 40 diferentes países, entre a Ásia, África, Oceania, América do Sul e Norte (Bové, 2006b).

É uma doença bacteriana que atinge o líber ou floema, que são vasos condutores de seiva, ou seja, inibem o transporte de seiva elaborada para a planta, impedindo a distribuição de açucares para os demais órgãos das plantas.

O Greening no Brasil foi confirmado em julho de 2004, na região de Araraquara, estado de São Paulo. Hoje é a doença mais temida entre os produtores de laranja por não possuir cura nem tratamento, por ter um alto poder de disseminação e afetar todas as variedades comerciais de laranjeira. Com isso o Greening é a doença que mais preocupa os citricultores e os setores responsáveis por controlar doenças de citros, Fundo de Defesa de Citricultura (Fundecitrus).

\subsubsection{SINTOMAS DO GREENING}

Os sintomas do Greening são os mesmos, independentes da região ou país que ocorre à doença. Árvores afetadas têm como sintoma inicial o surgimento de um ramo com folhas, que se destacam pela cor amarela em contraste com a coloração verde das folhas dos ramos não afetados. As folhas sintomáticas apresentam coloração amarela pálida, com áreas de cor verde, formando manchas irregulares, chamadas de mosqueadas (Figura 2.7). 

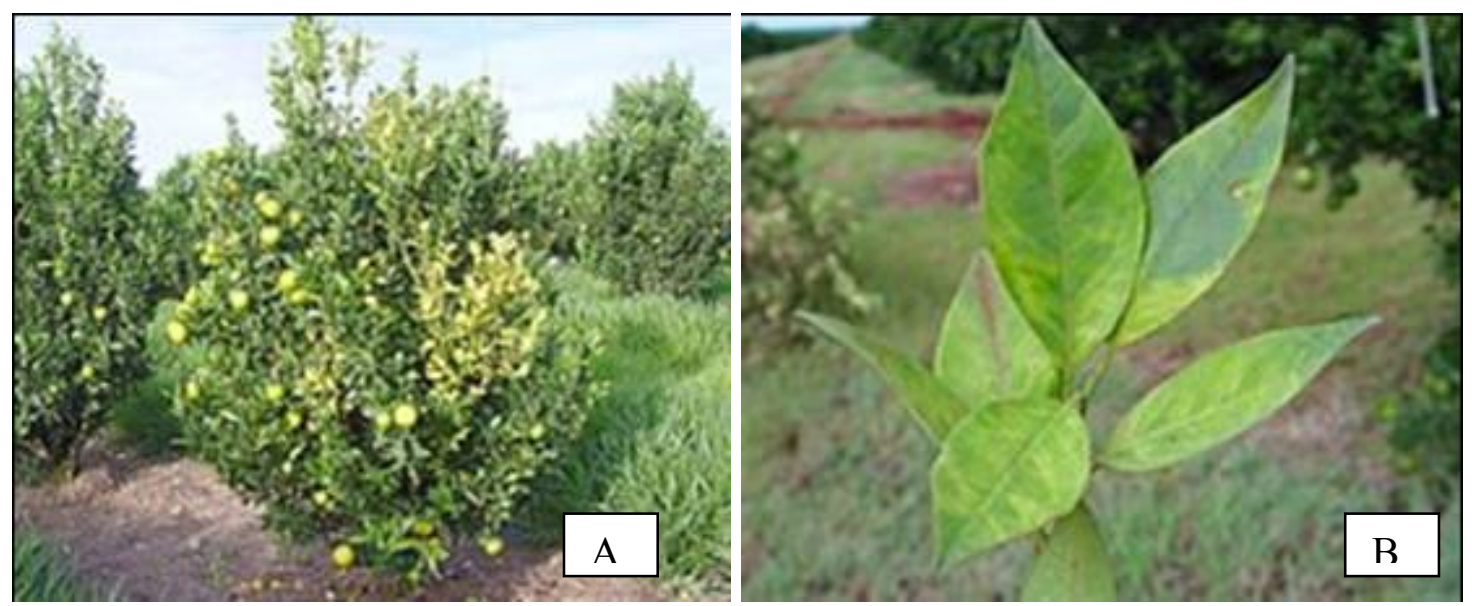

Figura 2.7 - Laranjeira com Greening mostrando o amarelecimento de galhos e folhas contrastando com o verde das folhas e ramos não afetados (A) e folhas contaminadas mostrando as irregularidades das manchas amareladas, chamadas de folhas mosqueadas (B). Fonte: Fundecitrus.

As árvores param de crescer e definham. Galhos afetados geram irregularidades nos frutos, ou seja, frutos menores e de forma irregular. Cortando o fruto afetado, é possível verificar internamente filetes alaranjados que partem da região de inserção com o pedúnculo. O fruto pode apresentar internamente diferenças de maturação. Ao cortar o fruto ao meio é possível observar que um lado do fruto está maduro (amarelo) e o outro ainda se encontra verde. A parte branca da casca, em alguns casos, apresenta espessura maior que o normal (Figura 2.8). É bastante comum, também, a ocorrência de sementes abortadas (sementes escurecidas) (Figura 2.9). 

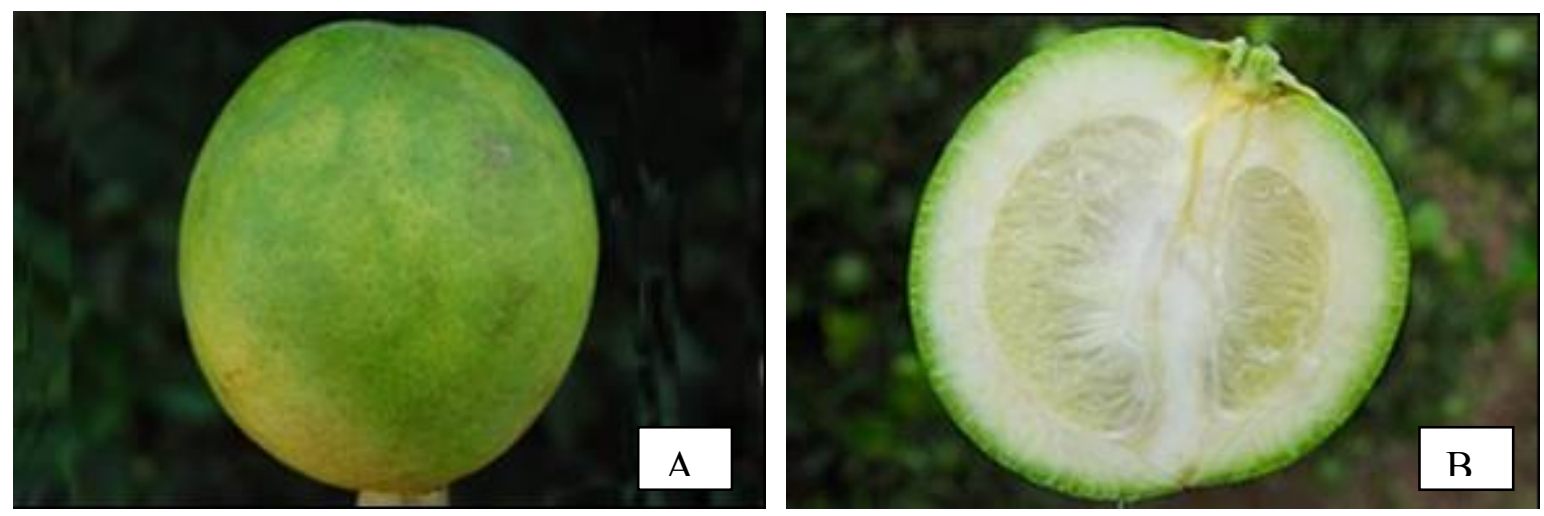

Figura 2.8 - Fruto de planta contaminada com Greening possui tamanho irregular e a casca verde pálido (A) e o corte longitudinal do mesmo mostra filetes alaranjados no pedúnculo e a diferença de maturidade do fruto e também uma maior espessura da parte branca do fruto (B). Fonte: Fundecitrus.

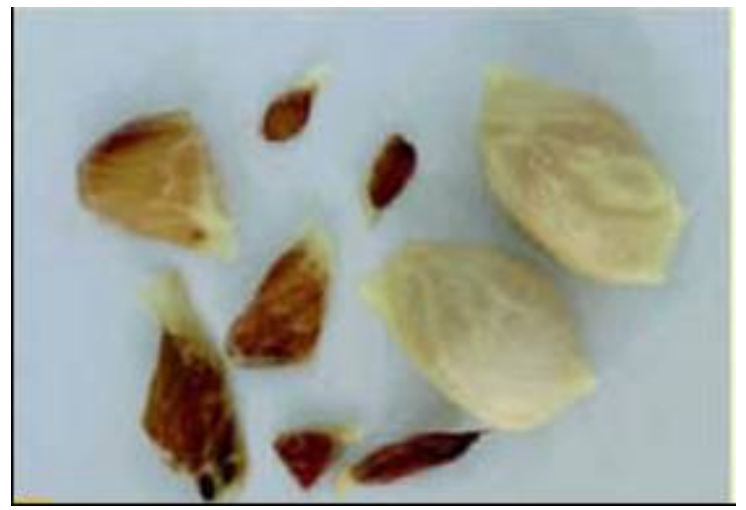

Figura 2.9 - Sementes sadias à esquerda e sementes abortadas a direita. As sementes abortadas possuem uma diferença de coloração, mais escuras. Fonte: Fundecitrus.

\subsubsection{DISTRIBUIÇÃO DA DOENÇA}

Por inspeção do Fundecitrus já foi possível diagnosticar o Greening em mais de 200 municípios do estado de São Paulo, 2 em Minas Gerais e 29 no Paraná (Fundecitrus), a região mais seriamente afetada é a região de Araraquara (Ayres, 2006). 
As inspeções são feitas por meio visual e realizadas por técnicos treinados pelo Fundecitrus. Estima-se que desde sua descoberta em 2004 até junho de 2006 mais de 500 mil plantas já foram erradicados.

Os municípios aonde foram constatados o Greening são: Aguaí, Agudos, Américo Brasiliense, Amparo, Analândia, Anhembi, Araraquara, Araras, Artur Nogueira, Avaré, Bariri, Bauru, Boa Esperança do Sul, Bocaina, Bofete, Borborema, Botucatu, Brotas, Cafelândia, Cajuru, Capela do Alto, Casa Branca, Cesário Lange, Conchal, Cordeirópolis, Corumbataí, Cravinhos, Descalvado, Dourado, Eng. Coelho, Espírito Santo do Pinhal, Gavião Peixoto, Guarapiranga (distrito), Iacanga, Ibaté, Itaju, Itapetininga, Itápolis, Itatinga, Itirapina, Jaboticabal, Leme, Limeira,Luiz Antonio, Lupercio, Matão, Mococa, Mogi Guaçu, Mogi Mirim, Monte Alto, Monte Santo de Minas (MG), Motoca, Nova Europa, Paranapanema, Pederneiras, Piracicaba, Pirajuí, Piranji, Pirassununga, Pitangueiras, Porto Ferreira, Reginópolis, Ribeirão Bonito, Rincão, Rio Claro, Santa Cruz da Conceição, Santa Cruz das Palmeiras, Santa Cruz do Rio Pardo, Santa Ernestina, Santa Lucia, Santa Rita do Passa Quatro ,Santa Rosa do Viterbo, São Carlos, São João da Boa Vista, São Manoel, São Simão, Tabatinga, Taiaçu, Tiuva, Tambau , Taquaral, Taquaritinga, Tatuí e Uru (Figura 2.10). 


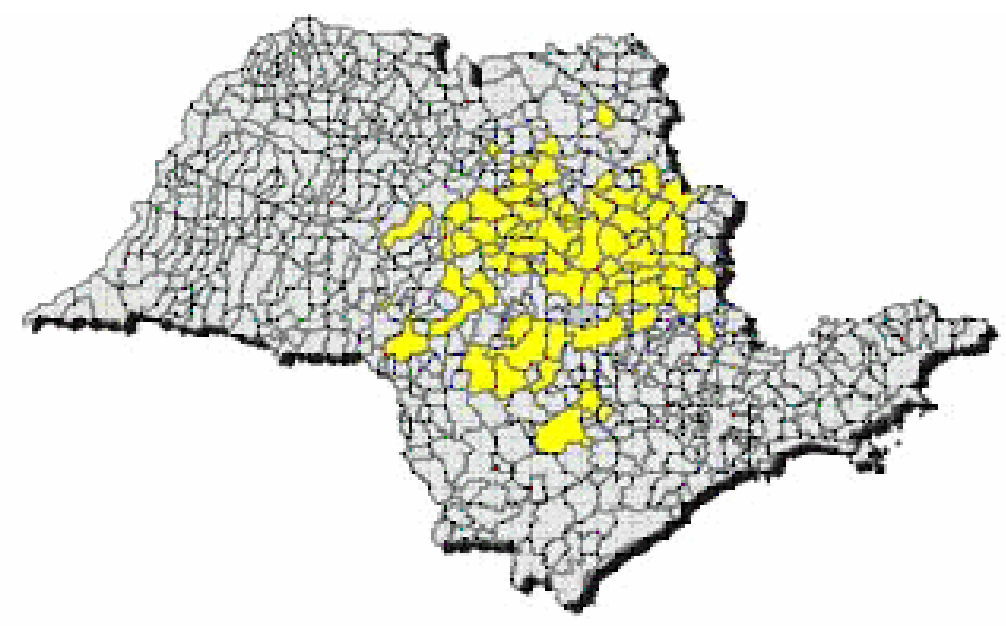

Figura 2.10 - Mapa da distribuição do Greening no estado de São Paulo, atingindo quase 200 municípios.

\subsubsection{ETIOLOGIA}

Os sintomas do Greening são virtualmente os mesmos, independente de onde ocorre a doença. A microscopia eletrônica foi a primeira técnica fidedigna de diagnose do Greening. Anticorpos monoclonais foram considerados muito específicos para a detecção de Liberibacter em imunização, e foram uma decepção como diagnóstico. Hoje, outros métodos laboratoriais são usados para rotina de detecção e confirmação do sintoma do Greening: hibridização 'dot blot' com sonda especifica para Liberibacter, e usada para detecção em população de psilídeos, e diversos formatos de PCR (convencional, 'nested, multiplex) usando primers específicos, para cada espécie de Liberibacter e baseado no 16S rDNA ou rplKAJL-rpoBC na seqüência do operon.

Folhas com sintomas de manchas-mosqueadas geram PCRs positivos em 99\% dos casos. Com folhas com sintomas de árvores afetadas, somente 10\% das amostras geram PCRs positivos. Como mostrado primeiramente por Lin Kung Hsiangno sul da China em 1956, o Greening pode ser transmitido por inoculação de enxerto de citros para citros. Experimentalmente a 
'Dodder'(Cuscuta campestris) é capaz de transmitir as três espécies de Liberibacter para plantas de vinca (Catharanthus roseus).

O psilídeo africano, Trioza erytreae, é o vetor natural do C. L. africanus na África, e o psilídeo asiático Diaphorina citri, transmite a C. L. asiaticus sob condições naturais na Ásia. Experimentalmente, cada uma das espécies de psilídeo foi capaz de transmitir ambas as espécies de C. Liberibacter, o asiaticus.

No estado de São Paulo, em abril de 2004, muitas amostras de folhas de citros mosqueadas com sintomas característicos de Greening tiveram resultados de PCRs negativo em reações quando testadas com primers específicos para "africanus" e/ou "asiaticus". Isto sugeriu que folhas com manchas mosqueadas foram infectadas com uma nova bactéria. De fato, como já descrito usando primers universais f-D1/r-P1 em DNA de citros de folhas com manchas mosqueadas uma nova espécie Liberibacter foi descoberta: Candidatus Liberibacter americanus. Na comparação filogenética baseado no $16 \mathrm{~S}$ rDNA, o novo Liberibacter não se agrupou dentro do grupo "asiaticus/ africanus", mas formou uma ramificação separada. Para dada espécie de Liberibacter, o IR (região intergênica) é altamente conservada: duas variantes diferentes da mesma espécie têm de 99 a 100\% de seqüência idêntica. Porém, um variante de uma espécie é comparada com um variante de espécie diferente, a semelhança é abaixo de 76\%. Estes resultados confirmam que "africanus", "asiaticus" e "americanus" são três espécies diferentes de Liberibacter (Bové, 2006a).

\subsubsection{VETOR}

A bactéria Candidatus Liberibacter, nas duas formas asiaticus e americanus, também foram encontradas na planta ornamental Murraya paniculata, conhecida popularmente como 
murta, falsa murta ou murta de cheiro (Figura 2.11), também hospedeira do vetor da bactéria e este é conhecido como psilídeo, Diaphorina citri (D. citri) (Figura 2.12).
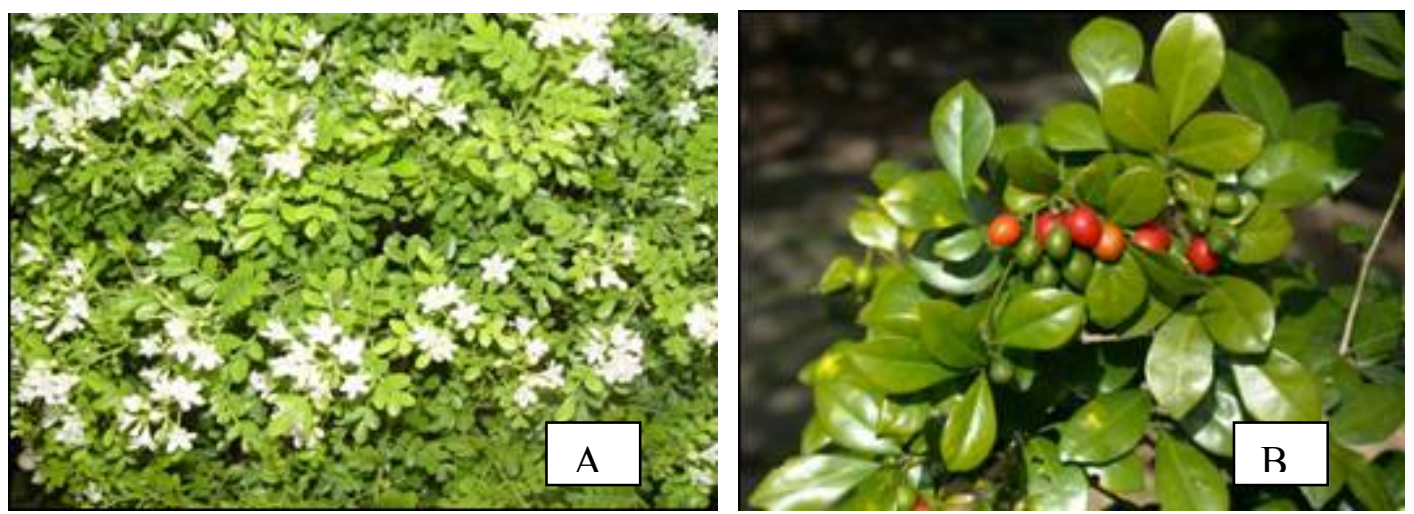

Figura 2.11 - Foto da florada (A) e do fruto (B) da Murraya paniculata, conhecida como murta, planta ornamental hospedeira da bactéria Candidatus Liberibacter. Fonte: Fundecitrus.

A D. citri é um inseto de aproximadamente $3 \mathrm{~mm}$ de comprimento, possui coloração cinza e manchas escuras nas assas. Não possui limitação climática e atinge todas as variedades de citros e murta. Permanece nas folhas e ramos em uma inclinação de $45^{\circ}$, uma característica peculiar que ajuda no seu reconhecimento (Figura 2.12). Os psilídeos se alimentam tanto em folhas maduras como em brotos novos. Entretanto, coloca seus ovos apenas em brotos novos, local onde as ninfas se desenvolvem. Uma vez que o inseto adquiriu a bactéria, mesmo em estagio de ninfa, ele nunca mais a perde (Manual Greening 2007, Fundecitrus). 

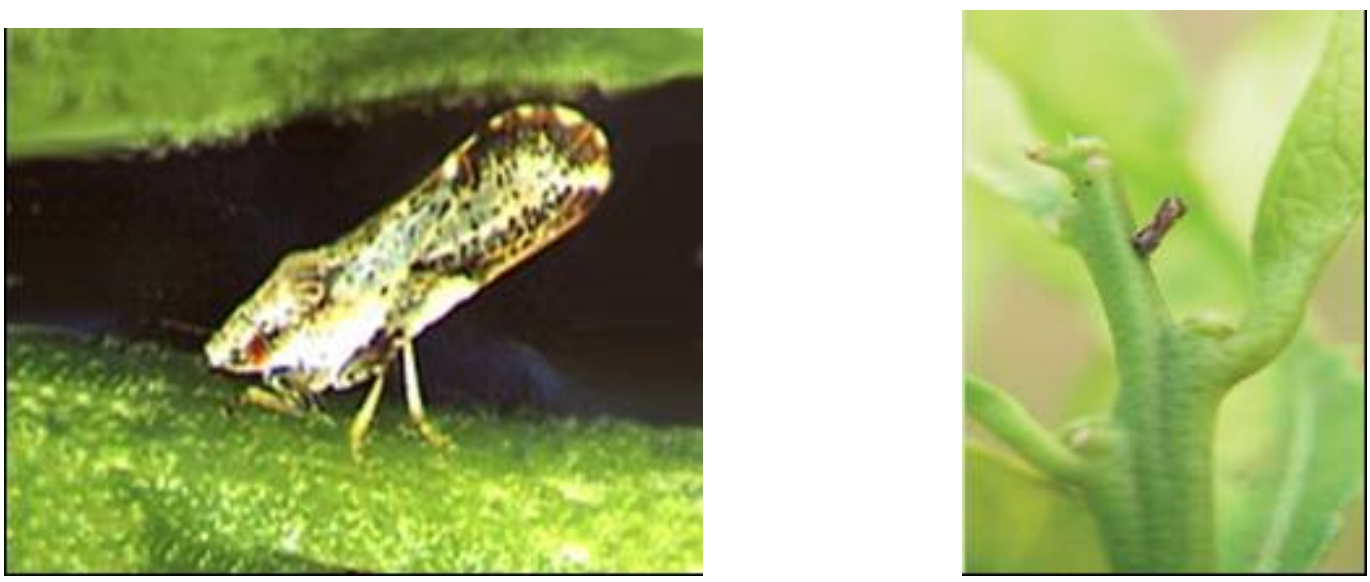

Figura 2.12 - Imagem da Diaphorina citri, inseto cinza, com $3 \mathrm{~mm}$ de comprimento e asas manchadas (A) o inseto a $45^{\circ}$ no ramo, característica peculiar da D.citri (B). Fonte: Vivernatural.

\subsubsection{MANEJO DA DOENÇA}

A partir do ramo infectado a bactéria se espalha por toda a extensão da planta, atingindo toda a copa e tornando a produção desprezível. Quando se observa galho das extremidades da copa amarelado, a bactéria já pode estar alojada embaixo do tronco e raízes. Por ser uma doença que atinge o transporte de seiva elaborada, floema, ela torna a plantas novas improdutivas e as plantas mais maduras diminuem a produção até não produzirem mais.

Por ser uma doença altamente devastadora, inúmeros cuidados devem ser tomados com os pomares já produtivos e os que ainda estão em fase inicial de plantio. Para tal, existem cinco medidas a serem adotadas:

1. Inspeção nos pomares

2. Arranque de árvores contaminadas

3. Controle do vetor

4. Mudas sadias

5. Eliminação das murtas 
As inspeções nos pomares devem ser feitas periodicamente por técnicos devidamente treinados. Este treinamento é fornecido por inspetores do fundecitrus. Sugere-se que as inspeções sejam feitas pelo menos 4 vezes ao ano, mas o ideal é que essas inspeções sejam realizadas mensalmente na propriedade. Assim, diagnosticado os sintomas da doença, o pé de laranja deve ser imediatamente arrancado. A poda não é o suficiente para barrar a doença (Manual de Greening, Fundecitrus, 2007). Em março de 2005 o Ministério da Agricultura publicou uma instrução Normativa tornando obrigatória à eliminação de plantas cítricas e da murta, com sintomas da doença.

Como a bactéria causadora do Greening não é transmitida pelo vento, nem água, nem por máquinas e equipamentos agrícolas, nem tão pouco por operários, a bactéria é transmitida no pomar apenas por insetos contaminados, ou seja, o controle desse inseto vetor é de suma importância para a sanidade do pomar. A D.citri deve ser monitorada por armadilhas adesivas colocadas em locais estratégicos e a partir dessas armadilhas pode-se decidir o momento de fazer pulverizações com inseticidas.

A procedência das mudas e a garantia de sua sanidade são de extrema importância, ou seja, adquirir mudas apenas de viveiros protegidos devidamente cadastrados na Coordenadoria de Defesa Agropecuária (CDA).

\subsection{PIGMENTOS VEGETAIS}

Dentre os grupos de pigmentos das plantas, três deles sobressaem-se pela importância biológica e a freqüência com o qual eles ocorrem nas angiospermas: as clorofilas, os carotenóides e as antocianinas.

As clorofilas e os carotenóides participam do processo fotossintético e as antocianinas ocorrem freqüentemente em flores e frutos, colaborando para a atração de polinizadores e 
dispersores de sementes, respectivamente. Os carotenóides, em sua maioria, são amarelos ou alaranjados.

As clorofilas que ocorrem nas angiospermas são as clorofilas $\boldsymbol{a}$ e $\boldsymbol{b}$. Estes são os pigmentos que dão às plantas sua coloração verde característica. A clorofila $\boldsymbol{a}$ é verde azulada e a clorofila $\boldsymbol{b}$ é verde amarelada. A clorofila $\boldsymbol{a}$ ocorre em todos os organismos fotossintéticos que liberam $\mathrm{O}_{2}$ e tem como função realizar as etapas fotoquímicas, que é o primeiro estágio fotossintético (Streit et al., 2005). A clorofila $\boldsymbol{b}$, cujo teor é 1/3 da clorofila $\boldsymbol{a}$ (Hall e Rao, 1980) é sintetizada a partir da oxidação do grupo metil da clorofila $\boldsymbol{a}$ para um grupo aldeído (Streit et al., 2005).

A formula molecular da clorofila $\boldsymbol{a}$ é $\mathrm{C}_{55} \mathrm{H}_{72} \mathrm{~N}_{4} \mathrm{O}_{5} \mathrm{Mg}$ e a da clorofila $\boldsymbol{b} \mathrm{C}_{55} \mathrm{H}_{70} \mathrm{~N}_{4} \mathrm{O}_{6} \mathrm{Mg}$. A molécula de clorofila contém uma "cabeça" porfirínico e uma "calda" de fitol. O grupo porfirínica polar (relativamente solúvel em água) é composto de um anel tetrapirrólico e um átomo de magnésio. Na clorofila $\boldsymbol{b}$, o grupo $-\mathrm{CH}_{3}$ do segundo anel pirrólico é substituído pelo grupo $-\mathrm{COH}$ (Figura 2.13). 


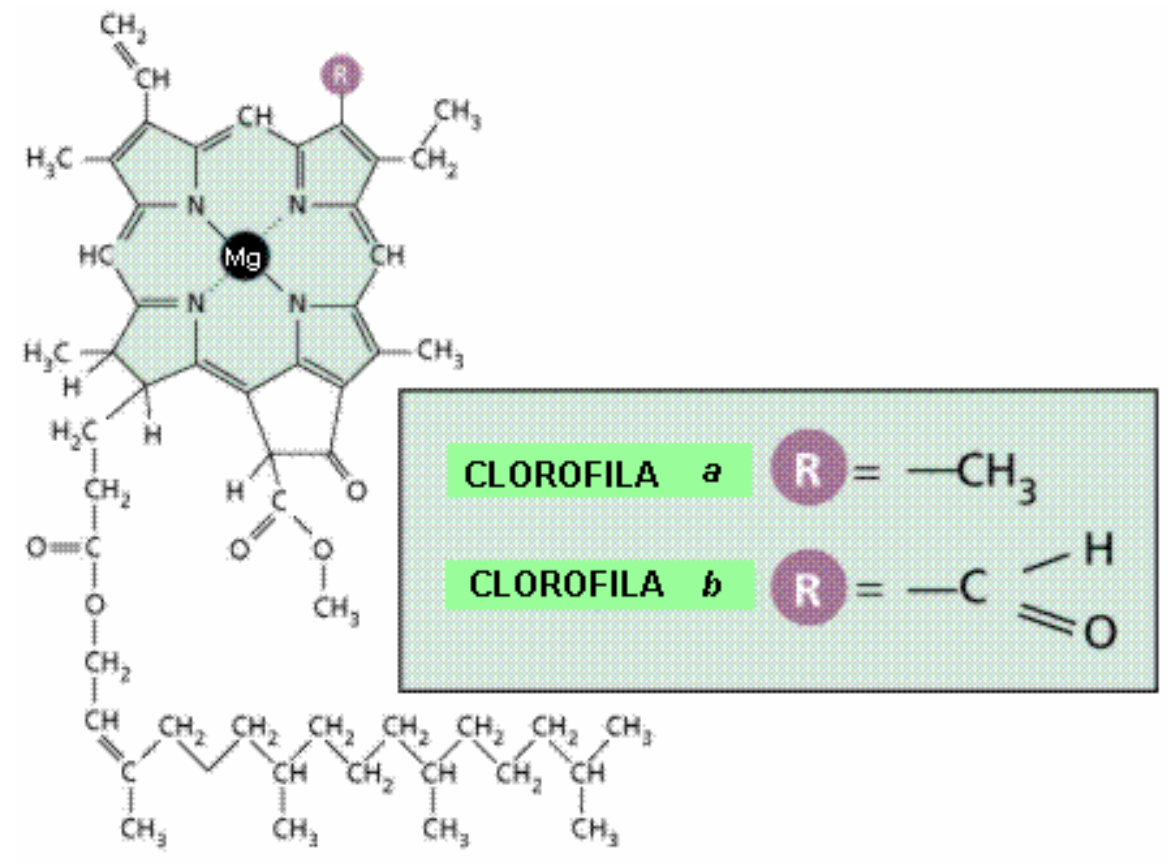

Figura 2.13 - Representação gráfica da clorofila a e da clorofila b, onde a diferenciação da clorofila a e b é apenas a substituição do radical $R$ por um hidrocarboneto (clorofila a) ou por um aldeído (clorofila b).

\subsection{ESPECTROSCOPIA DE FLUORESCÊNCIA}

As moléculas possuem um estado fundamental com elétrons de valência que ocupam o mesmo orbital tendo spins antiparalelos. O spin resultante $\mathrm{S}$ dos elétrons é zero, e a multiciplidade do nível, que é dada por $|2 \mathrm{~S}|+1$, será igual a 1 . Sendo assim, em geral as moléculas possuem um estado fundamental do tipo singleto $\left(\mathrm{S}_{0}\right)$. Se o estado excitado permite a inversão de spin de um dos elétrons, o spin total será unitário, e a multiplicidade do estado igual a 3. Tais estados são chamados de tripleto $T^{*}$. Se a absorção de um quantum de luz não leva a qualquer mudança de orientação de spin, o estado excitado correspondente será um estado singleto $\mathrm{S}^{*}$. 
A figura 14 mostra a configuração de níveis de energia de uma molécula orgânica. Nessa figura podem-se observar os processos de absorção de energia, entre o estado fundamental $\mathrm{S}_{0}$ e os estados singletos $\mathrm{S}_{1}, \mathrm{~S}_{2}, \mathrm{~S}_{3}$, etc. e os conseqüentes mecanismos de emissão e dissipação da mesma, que envolvem transições radioativas e não-radioativas entre níveis eletrônicos. $\mathrm{O}$ fenômeno de absorção de energia possui um tempo característico da ordem de $10^{-15} \mathrm{~s}$, intervalo suficientemente curto para que o núcleo atômico não sinta a transferência de momento, resultando na transição de um estado vibracional estável para outro instável. O tempo de vida característico de um estado excitado é da ordem de $10^{-8} \mathrm{~s}$. Este tempo é longo o suficiente para que o sistema possa perder energia através de modos vibracionais, rotações e/ou translações moleculares, cujos tempos característicos são da ordem de $10^{-12} \mathrm{~s}$, sendo assim ocorre a dissipação da energia por vias não radiativas.

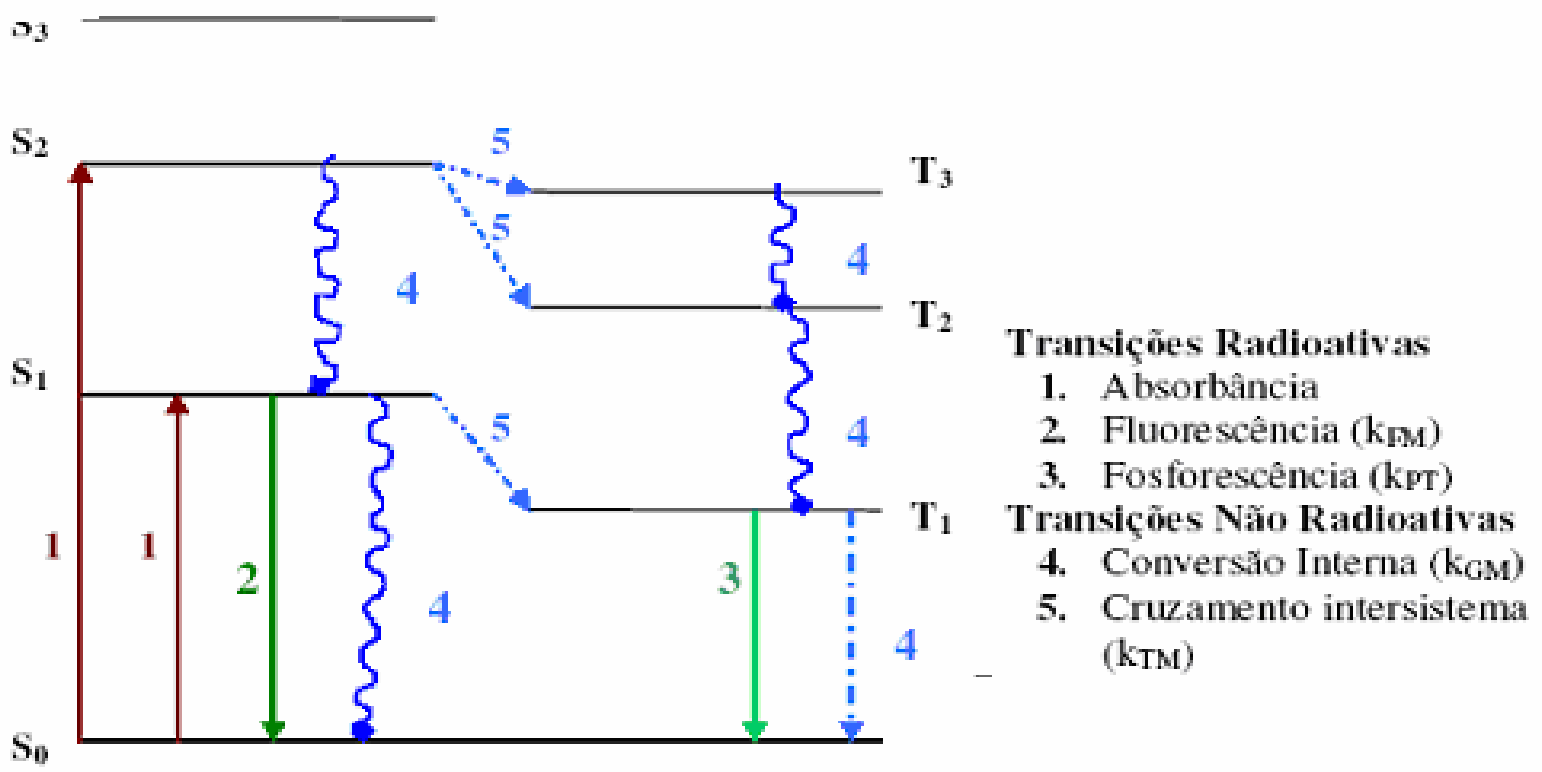

Figura 2.14: Configuração energética de uma molécula orgânica e suas transições eletrônicas.

Entretanto, existem também transições radiativas que envolvem emissão de energia na forma de radiação, esta emissão é chamada "fluorescência", que terá sempre uma menor 
magnitude que a energia de excitação da molécula, e embora possa ser produzida a partir de qualquer dos estados excitados singleto $\mathrm{S}_{1}, \mathrm{~S}_{2}$ e $\mathrm{S}_{3}$, a "fluorescência primária" geralmente ocorre a partir do menor estado excitado singleto S1, sem considerar o estado inicial de excitação. O tempo de vida deste estado é da ordem de $10^{-9} \mathrm{~s}$. As transições radiativas a partir de níveis superiores $\mathrm{S}_{2}, \mathrm{~S}_{3}$, etc. são pouco prováveis devido à competição do processo de conversão interna entre $\mathrm{S}_{2}$ e $\mathrm{S}_{3}$. Por outro lado, transições eletrônicas entre estados tripleto e estados singleto são proibidas pelas regras de seleção da mecânica quântica (Lumb, 1978).

Os processos não radiativos também desenvolvem um papel importante no processo de fluorescência, entre eles podem se mencionar: conversão interna ou desativação colisional e cruzamento intersistemas. A conversão interna resulta em um mecanismo não radiativo para a relaxação do estado excitado. Em geral, fatores que aumentam a interação das moléculas com seu meio (solvatação, temperatura, flexibilidade molecular) aceleram a taxa de conversão interna por desativação colisional (Senesi, 1990b).

O cruzamento intersistemas decorrente da mudança do estado de spin do elétron (por exemplo: converta $\downarrow \uparrow$ em $\uparrow \uparrow)$, envolve uma transferência não radioativa de energia do estado singleto até o estado tripleto e vice-versa $\left(\mathrm{S}_{1} \rightarrow \mathrm{T}_{1}\right.$ da Figura 2.14).

Se em uma molécula excitada ocorre este tipo de transição, ela tende a dissipar sua energia, descendo os níveis vibracionais do estado tripleto $\left(\mathrm{T}_{3} \rightarrow \mathrm{T}_{2}\right)$, que possuem menor energia que o estado singleto correspondente (regra de Hund). Ao atingir o nível vibracional de menor energia do estado molecular eletronicamente excitado $\left(\mathrm{T}_{1}\right)$ a transição para o estado singleto fundamental a princípio não seria permitida, pois viola uma regra de seleção $(\Delta S=0$, ou seja, não pode haver variação no spin total da molécula). Neste estado, o decaimento ao estado fundamental por emissão radiativa de um fóton de maior comprimento de onda é denominado 
fosforescência. Como a taxa de cruzamento intersistemas é baixa (até $10^{1} \mathrm{~s}^{-1}$ ), a fosforescência é um processo "lento".

Os espectros de emissão da florescência são obtidos medindo a intensidade de radiação emitida em função do comprimento de onda $(\lambda)$, mantendo fixo o $\lambda$ de excitação, enquanto que os espectros de excitação são obtidos pela medida da intensidade de excitação, fixando o $\lambda$ de emissão. Os espectros com varredura sincronizada são obtidos combinando os modos de excitação e emissão, com a variação dos $\lambda$ tanto de excitação quanto de emissão fixando uma diferença constante entre eles de $\Delta \lambda=\lambda_{\text {em }}-\lambda_{\text {exc }}$, entre eles. Esta diferença pode aumentar a resolução espectral, permitindo a identificação de bandas adicionais.

A fluorescência é também uma técnica bastante seletiva, uma vez que ambos os comprimentos de onda, de excitação e emissão, dependem da estrutura molecular. Assim, a intensidade de fluorescência tem sido correlacionada com o tamanho molecular e o grau de policondensação de estruturas aromáticas (Chen et al., 2003).

Embora os espectros de fluorescência das folhas e extrato sejam uma somatória das respostas dos diversos fluoróforos presentes, esta espectroscopia se mostra útil para identificação de doenças de citros. As propriedades espectrais como a posição, deslocamento, largura de bandas e intensidade de picos são as principais informações para sua interpretação.

\subsubsection{FLUORESCÊNCIA INDUZIDA POR LASER (FIL)}

A fluorescência induzida por laser (FIL) tem o mesmo princípio do fenômeno da espectroscopia de fluorescência. Sua diferença em relação ao fluorímetro está no fato de que a radiação incidente é do tipo laser. As vantagens de se utilizar o laser como fonte emissora são sua 
monocromaticidade (o que melhora a precisão dos resultados), direcionalidade (não há desperdício de fótons pelo espalhamento em todas as direções) e intensidade.

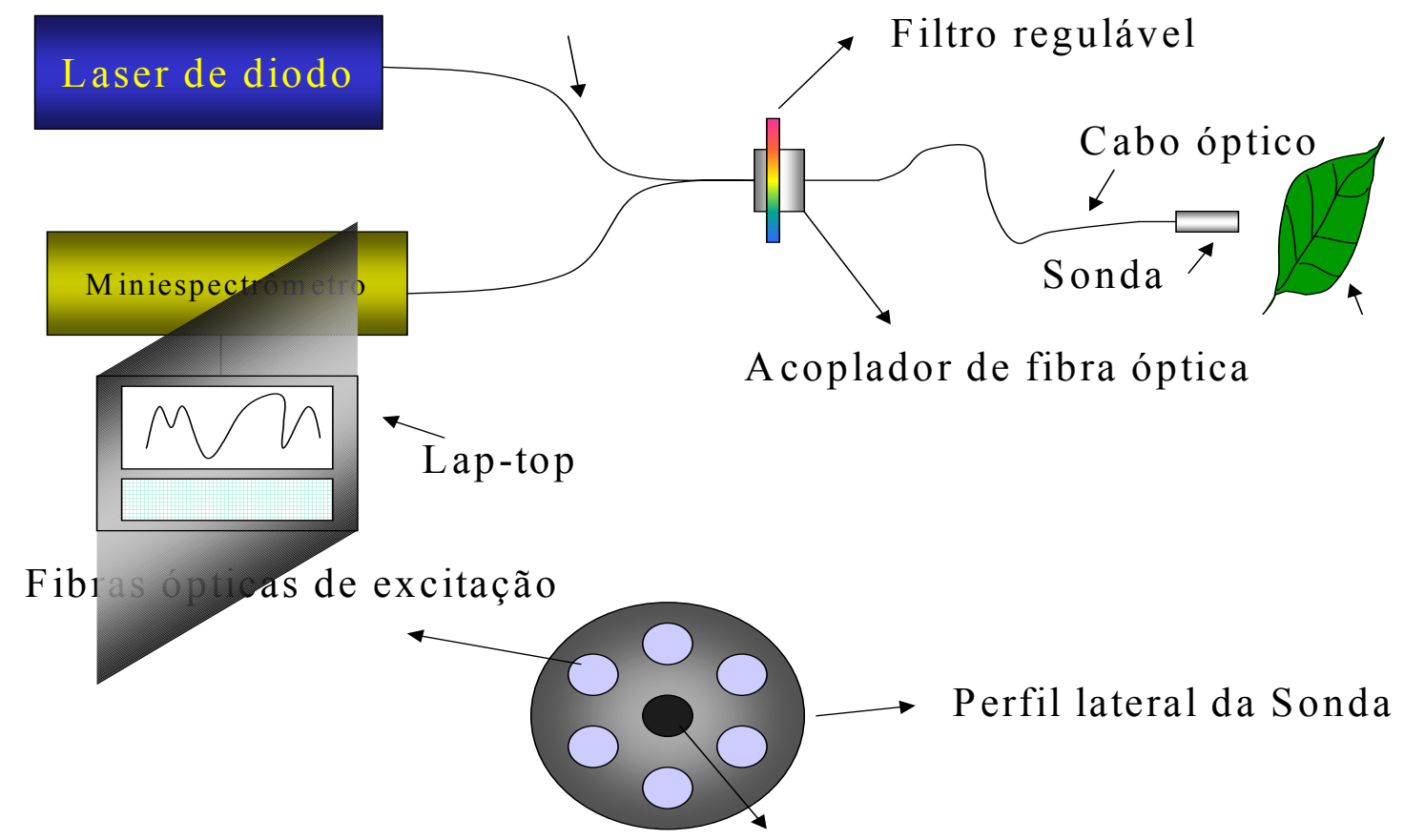

Fibra óptica para coletar emissão

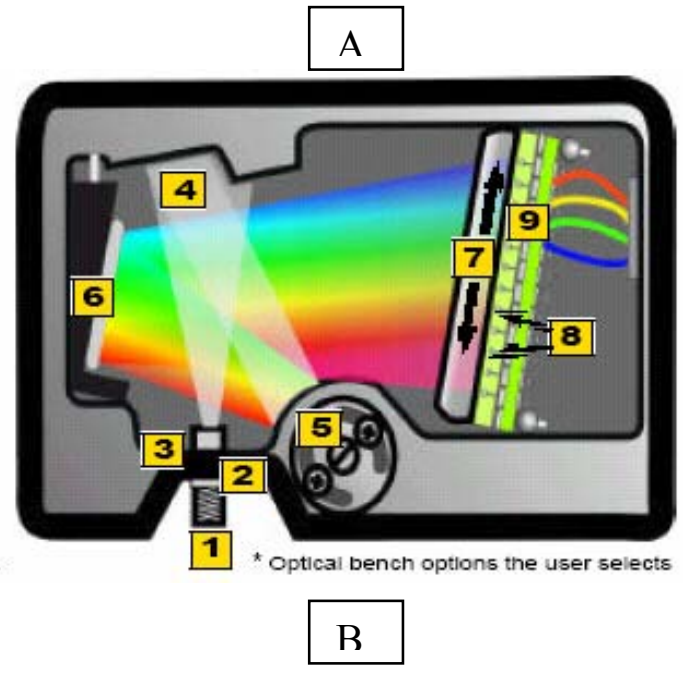

Figura 2.15: Esquema do sistema portátil para realização de medidas de FIL(A) detalhe do funcionamento do mini-espectrômetro: (1) entrada de luz através de uma fibra óptica (2) e (3) sistema de acoplamento da fibra com o mini-espectrômetro (4) espelho plano (5) espelho esférico (6) grade de difração (7) sistema de detecção composto de um conjunto de fotodiodos calibrados (B). 


\subsubsection{FLUORESCÊNCIA FOLIAR}

A fluorescência foliar já foi alvo de vários estudos, pois se trata de um método rápido, prático e não invasivo. Por exemplo, Schweiger et al. (1995) utilizaram este método como forma de detecção do estresse hídrico em Fagus sylvatica $L$.

As moléculas de clorofila absorvem a energia luminosa (fótons) e alteram temporariamente as suas configurações eletrônicas. Estes pigmentos passam do estado fundamental singleto para um estado excitado singleto com tempo de vida característico da ordem de $\approx 10^{-8} \mathrm{~s}$. Após este período, esta energia pode ser dissipada através de três processos;

- Dissipação fotoquímica: onde a energia luminosa é utilizada para os processos fotoquímicos da fotossíntese.

- Fluorescência: onde ocorre a emissão de radiação na região do visível.

- Dissipação não-fotoquimica: onde ocorre a produção de calor na forma de radiação infravermelha.

\subsection{ANÁLISE DE COMPONENTES PRINCIPAIS (PCA)}

Esse método se aplica em qualquer caso em que um conjunto de $\mathrm{n}$ amostras tenha sido examinado e seja identificado por um conjunto de $\mathrm{m}$ valores associados a $\mathrm{m}$ variáveis. Essas variáveis são tomadas como coordenadas que identificam uma amostra num espaço vetorial de dimensão m. A essência do método consiste em modificar esse sistema de coordenadas de modo a tornar evidentes os agrupamentos de amostras que possuam características essenciais em comum, distinguindo-as de outras amostras que possuem características diferentes. As mudanças de coordenadas se dão por rotações, mas podem ser aplicadas translações e redimensionamento 
das variáveis do sistema na fase de pré-processamento dos dados, isto é, antes da aplicação do PCA.

A questão a ser resolvida pelo PCA é, naturalmente, qual modificação efetuar de modo a tornar os agrupamentos e as separações tão nítidas quanto for possível. O problema é resolvido com base no fato algebricamente demonstrável de que a soma dos autovalores da matriz de covariância dos dados (que é uma matriz quadrada de ordem m cujos autovalores são todos positivos) é igual à variância total dos dados. Isso permite inferir que a cada autovalor está associada uma determinada parcela da variância. Na verdade, como a matriz de covariância é ortogonal, seus autovetores constituem uma base ortogonal, de modo que os dados podem ser escritos nessa nova base por uma mudança de coordenadas simples.

O quociente de cada autovalor pela variância total fornece, assim, a proporção da variância abrangida pelo autovetor associado, o qual é, por sua vez, uma combinação linear das variáveis originais do problema. Então, organizando os autovetores por ordem decrescente dos autovalores correspondentes, obtém-se uma hierarquia de relevância na determinação das características essenciais dos dados.

As variáveis nesse novo sistema de eixos são denominadas "componentes principais", advindo daí o nome do método. A primeira componente principal concentra em si uma parcela pelo menos relativamente grande do que é relevante na distinção entre as diversas amostras, pois a variância associada a ela é maior que qualquer outra. A segunda componente principal é responsável por uma fração significativa da variabilidade restante, e assim sucessivamente. Dessa forma, um número relativamente pequeno de variáveis permite apreender todas ou quase todas as informações relevantes que podem ser extraídas de um conjunto de dados. 
O método PCA tem encontrado aplicações nos mais diversos campos de estudo, onde quer que seja necessário lidar simultaneamente com um grande número de variáveis. Exemplos podem ser encontrados: nas ciências ambientais, que inclui o estudo de contaminantes presentes em alimentos (Kobayashi et al, 2008); nas ciências da computação, em especial como técnica de compressão de imagens (Abadpour et al, 2008); na meteorologia, como num estudo de variações na intensidade das chuvas ao longo dos anos (Maraun et al, 2008); e na bioquímica, onde serve, dentre outras coisas, para identificar proteínas cujo funcionamento é afetado pela deficiência de zinco (Beattie et al, 2008). Porém, em nenhum campo o PCA encontra mais aplicações do que na química analítica, onde tem servido a propósitos tão diversos quanto a análise espectroscópica da biodegradação do petróleo (Abbas et al, 2008), o estudo da adsorção em filmes de proteínas (Bernsmann et al, 2008) e a classificação de vinhos por sensores amperométricos (Pigani et al, 2008), dentre muitos exemplos que poderiam ser citados. 


\section{CAPÍTULO 3 OBJETIVO}

Trabalho realizado anteriormente no Laboratório de Óptica e Lasers da Embrapa Instrumentação Agropecuária LOLEIA (Terêncio, 2006), mostrou a possibilidade de se distinguir folhas saudáveis de doentes, e também, de se distinguir doenças (MSC e Declínio) através da razão entre os picos do espectro de emissão de fluorescência utilizando-se espectrômetros comerciais.

Visando a disponibilização de um sistema portátil mais rápido e preciso, o LOLEIA desenvolveu em 2007 um sistema utilizando FIL com uma sonda construída com fibras ópticas e sistema de deteç̧ão constituído por conjunto de fotodiodos calibrados que permite a obtenção do espectro de emissão da folha de forma extremamente rápida $(\sim 1 \mathrm{~s})$. Com este novo sistema tornou-se possível a realização de um grande número amostras em um curto período de tempo. Para tanto, foi necessário o desenvolvimento de protocolos de medidas com este equipamento.

O objetivo desse trabalho foi diagnosticar a MSC, o Declínio e o Greening de uma maneira economicamente viável, rápida, precisa (eliminando a subjetividade e diminuindo o erro) e até mesmo com certa precocidade.

Estudar também através da espectroscopia de fluorescência os extratos foliares de diferentes portas-enxerto e diferentes doenças. 
Com o objetivo de procurar alterações espectrais que pudessem diferenciar folhas saudáveis de doentes, foram medidos espectros de emissão de fluorescência tanto de folhas como de extratos foliares. A fluorescência das clorofilas como medida capaz de demonstrar o estado fisiológico dos tecidos tanto em folhas quanto para verificação do conteúdo clorofilático nas frutas já são conhecidos (Schreider et al., 1987 e DeEll et al., 2000). Com isso, espectros de emissão das folhas foram adquiridos com FIL já os espectros de fluorescência dos extratos foram obtidos em um espectrômetro de luminescência Perkin Ekmer LS-50B pertencente a Embrapa Instrumentação Agropecuária.

\subsection{FOLHAS}

Neste trabalho foram coletadas folhas saudáveis, sintomáticas com MSC, sintomáticas com Declínio, sintomáticas com Greening e assintomáticas, porém contaminadas com Greening.

As folhas sintomáticas com a MSC foram coletadas em dois níveis de severidade, MSC1 e MSC2, caracterizando os sintomas iniciais e avançados da doença, respectivamente. O diagnóstico de MSC na planta foi confirmado através do amarelecimento da casca na região de enxertia, já o diagnóstico positivo para o Declínio foi confirmado com o teste de injeção de água no tecido vegetal. A confirmação do Greening foi através do diagnóstico visual.

As folhas saudáveis foram adquiridas em regiões de baixa incidência de Greening e sem indícios de MSC e Declínio. As folhas assintomática de Greening foram coletadas em plantas onde havia o sintoma da doença, mas foram coletadas em galhos sem a expressão do mesmo. 
As folhas sintomáticas com MSC foram coletadas no sul do estado de Minas Gerias e norte do estado de São Paulo. As amostras sadias, com Greening e com Declínio foram coletadas na região central do estado de São Paulo. Todas as folhas foram coletadas por técnicos do Fundecitrus e da empresa Agrindus. Esses técnicos foram treinados para reconhecimento de tais doenças.

As análises foram feitas em árvores já adultas com idade entre 12 a 14 anos. As medidas foram feitas por conjunto de plantas com a mesma variedade e o mesmo porta-enxerto, e as folhas foram coletadas sempre na mesma altura e com a mesma localização na árvore, visando sempre minimizar o número de variáveis do sistema. As relações de amostras estão nas tabelas a baixo:

Tabela 4.1 - Amostras fornecidas pela Fundecitrus de laranja Hamlin, Valência, e Pêra em porta-enxerto de limão Cravo para análise de doenças.

\begin{tabular}{|l|l|l|l|l|}
\hline Fundecitrus & Hamlin & Valência & Pêra & Total \\
\hline Sadia & 81 & 75 & 50 & 206 \\
\hline MSC & 78 & 84 & 59 & 221 \\
\hline Greening Assintomática & 56 & 54 & 52 & 162 \\
\hline Greening Sintomática & 52 & 55 & 52 & 159 \\
\hline Declínio & 82 & 75 & 100 & 258 \\
\hline Total & 349 & 343 & 313 & 1005 \\
\hline
\end{tabular}

Tabela 4.2 - Amostras fornecidas pela Agrindus de laranja Pêra com porta-enxerto Sunki para analise de doenças.

\begin{tabular}{|l|l|}
\hline Sadia & 225 \\
\hline Greening Assintomática & 225 \\
\hline Greening Sintomática & 225 \\
\hline Total & 675 \\
\hline
\end{tabular}


Tabela 4.3 - Amostras fornecidas pela Agrindus de laranja Natal com porta-enxerto Trifoliata para análise de doenças

\begin{tabular}{|l|l|}
\hline Sadia & 41 \\
\hline Greening Asintomática & 36 \\
\hline Total & 77 \\
\hline
\end{tabular}

As amostras coletadas foram acondicionadas em sacos plásticos e estes foram fechados e devidamente etiquetados. Ainda no campo, as amostras foram armazenadas em caixas de isopor e transportadas até o laboratório. No laboratório, foram armazenadas em um sistema de refrigeração a uma temperatura $8^{\circ} \mathrm{C}$ por um período de aproximadamente 24 horas. Após este período foram enxaguadas com água destilada e seca com papel macio e absorvente para retirar a sujeira.

Após esse processo de transporte, armazenamento e limpeza das amostras, as medidas espectrais foram realizadas.

\subsubsection{EQUIPAMENTO E METODOLOGIA PARA AQUISIÇÃO DOS}

\section{DADOS}

Utilizou-se um sistema portátil de espectroscopia de fluorescência induzida por laser desenvolvido e construído no LOLEIA.

Esse sistema portátil foi construído com o objetivo de empregar a metodologia diretamente no campo. O sistema é composto por um laser de diodo da Coherent, modelo Compass 561-20, que emite em um comprimento de onda de 561nm (nanômetro) com $8 \mathrm{~mW}$ (miliWatts)de potência; e um miniespectrômetro Ocean Optics USB2000, que resolve o espectro de emissão proveniente da amostra; um conjunto de fibras ópticas que conduzem o laser da fonte à folha, e coleta a emissão; um filtro óptico ajustável, colocado entre a amostra e o miniespectrômetro e ajustado de modo a reduzir a intensidade da luz refletida pela folha e assim 
evitar danos aos sensores deste por excesso de intensidade luminosa e, finalmente, um sistema de refrigeração do equipamento.

Um estudo espectral de toda a superfície foliar foi realizado utilizando-se o sistema portátil descrito acima com o objetivo de avaliar as regiões com alterações mais significativas. Adquiriram-se, também, espectros nas duas superfícies foliares, dorsal e ventral. As regiões entre as nervuras de sustentação secundária foram utilizadas durante o processo de caracterização, evitando assim que novas substâncias químicas, como as fitoalexinas, mascarassem o resultado. A melhor resposta do sistema foi obtida na região ventral da folha, próximo ao pedúnculo. As curvas espectroscópicas obtidas nesta região da folha tiveram uma melhor resolução, com curvas e picos mais bem definidos, portanto, todas as medidas realizadas ao longo deste trabalho foram obtidas nesta região.

O tempo de integração utilizado foi de 30ms (milisegundo) o intervalo de leitura foi entre $541,43 \mathrm{~nm}$ a $1197,59 \mathrm{~nm}$ com uma intensidade do sinal que variava de zero a 4000 u.a. (unidade arbitrária). A sonda para realização das medidas foi sempre utilizada perpendicular à amostra, ou seja, a $90^{\circ}$ (Figura 4.1), as medidas foram feitas em temperatura ambiente e na presença de luz. Os dados foram coletados e armazenados através de um software desenvolvido no LOLEIA. A resolução do mesmo é de $4,25 \mathrm{~nm}$, estimativa essa feita baseada na altura do pico referente ao segundo harmônico. 


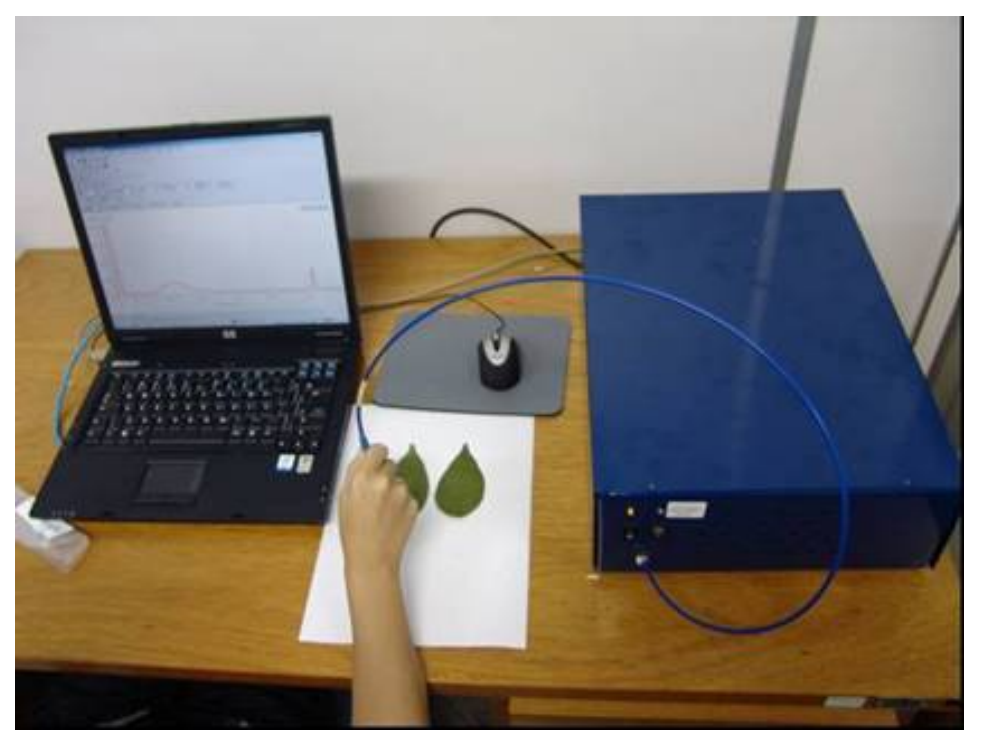

Figura 4.1 - Foto ilustrativa de como foram feitas às medidas nas folhas. A sonda é levada até a superfície da folha Os dados adquiridos são armazenados em um banco de dados.

\subsection{EXTRAÇÃO DOS PIGMENTOS FOTOSSINTÉTICOS}

Para melhor conhecimento e entendimento dos danos causados pelas doenças nas folhas de citros fez-se um estudo dos pigmentos fotossintéticos de algumas das amostras descritas anteriormente. Os extratos foram obtidos através do método descrito por Arnon (1949) que consiste na extração de pigmentos fotossintéticos com acetona.

Quatro folhas de cada amostra, devidamente limpas como descrito no item 4.1, foram trituradas em um liquidificador, retirando a nervura central. Posteriormente, este material foi transferido para um balão volumétrico de $100 \mathrm{~mL}$ e o seu volume foi completado com acetona P.A. O balão volumétrico foi envolto em papel alumínio e mantido em geladeira por 24 horas para evitar a degradação dos pigmentos. Após esse período, uma alíquota dessa solução foi transferida para um béquer previamente pesado. Esse béquer foi mantido aberto em geladeira para evaporação do solvente e concentração dos pigmentos. Após essa etapa, o béquer novamente 
foi pesado. Com o peso do extrato seco, fez-se uma diluição em acetona pura tendo o controle da concentração da mesma.

A extração dos pigmentos fotossintéticos foi feita com as folhas de árvores sadias, com MSC, Declínio, Greening sintomática (GS) e Greening assintomática (GA), para a variedade Pêra enxertada em limoeiro Cravo e enxertada em tangerina Cleópatra, como mostra a tabela 4.4

Os extratos diluídos foram analisados em um espectrômetro de luminescência da Perkin Elmer LS-50B. As medidas foram realizadas em modo de emissão com excitação em 560nm, varredura de 575 a $900 \mathrm{~nm}$, velocidade de $500 \mathrm{~nm} / \mathrm{min}$, e fendas de entrada e saída proporcionando uma resolução espectral de $10 \mathrm{~nm}$. Esse comprimento de onda de emissão foi escolhido para poder comparar com os dados obtidos no mini-espectrômetro.

Tabela 4.4 - Extratos analisados de folhas de laranja Pêra enxertada em Limão Cravo e Tangerina Cleópatra

\begin{tabular}{|l|c|c|}
\hline & Limão Cravo & Tangerina Cleópatra \\
\hline Sadia & 4 & 4 \\
\hline Declínio & 4 & 4 \\
\hline MSC & 4 & - \\
\hline Greening Assintomática & 4 & - \\
\hline Greening Sintomática & 4 & 4 \\
\hline
\end{tabular}

\subsection{PIGMENTOS PADRÕES}

Sabe-se que os pigmentos fotossintéticos, como a clorofila a e a clorofila b, são os pigmentos naturais mais abundantes das plantas (Streit et al., 2005). Padrões comerciais dessas clorofilas foram utilizados como referência para comparação com a fluorescência dos extratos. Os padrões comerciais de clorofila a e clorofila $\mathbf{b}$ adquiridos para este fim foram isolados a partir 
do espinafre e o isômero $\boldsymbol{\beta}: \boldsymbol{\alpha}$ caroteno foi isolado a partir da cenoura. Esses padrões são comercializados pela BioChemika com uma pureza de aproximadamente $95 \%$.

Os padrões de clorofila $\mathbf{a}$, clorofila $\mathbf{b}$ e $\boldsymbol{\beta}: \boldsymbol{\alpha}$ caroteno foram pesados e diluídos em acetona PA. A concentração de cada padrão foi mantida em 0,078 g/L.

As amostras citadas foram analisadas em um espectrômetro de luminescência da Perkin Elmer LS-50B. As medidas foram realizadas em modo de emissão com excitação em 560nm, varredura de 575 a $900 \mathrm{~nm}$, velocidade de $500 \mathrm{~nm} / \mathrm{min}$ e com fendas de entrada e saída de proporcionando uma resolução espectral de $10 \mathrm{~nm}$.

\subsection{FORMA DE ANÁLISE DOS RESULTADOS}

Os espectros de emissão de fluorescência das folhas obtidos através do sistema portátil de FIL foram analisados pelo método quimiométrico de análise de componentes principais (PCA).

A quimiometria foi feita com o auxílio do software Diagnóstico, desenvolvido no LOLEIA especificamente para auxiliar na organização e tratamento de dados do projeto sobre doenças de citros. O programa começa pré-processando os espectros selecionados pelo usuário através da padronização de cada ponto, ou seja, subtraindo a média e dividindo pelo desvio padrão, de modo que as intensidades de cada comprimento de onda obedeçam à distribuição normal padrão (média nula e variância unitária). A partir dos espectros pré-processados, o programa seleciona a região do espectro a ser analisada. Neste trabalho foi utilizado o intervalo de 600 a $900 \mathrm{~nm}$, que contém 878 pontos. A partir da tabela resultante, são finalmente determinados os valores das componentes principais, numerados segundo a ordem decrescente de suas respectivas variâncias. Para todos os conjuntos de dados apresentados neste trabalho, podese obter uma boa representação dos resultados por meio de gráficos que mostram três das quatro primeiras componentes principais. Isso é necessário porque, embora as componentes principais 
de índices menores concentrem uma maior proporção da variância do conjunto de dados, elas não necessariamente apresentam maior poder de distinção entre os diversos grupos de amostras. Portanto, apenas a análise visual dos gráficos pode dizer quais componentes principais são mais úteis para os propósitos do trabalho que está sendo feito. Em todos os casos, as três primeiras componentes principais abrangem juntas no mínimo $95 \%$ da variância total dos dados, e com quatro componentes é possível chegar a 99\%. 


\section{CAPÍTULO 5 RESULTADOS E DISCUSSÕES}

\subsection{EXTRATOS FOTOSSINTÉTICOS}

Nesta seção serão abordados os resultados referentes aos dados descritos no item 4.2. Os resultados são provenientes da extração dos pigmentos fotossintéticos de laranjeira Pêra enxertada em limoeiro Cravo e folhas de laranjeira Pêra enxertada em tangerina Cleópatra.

Os resultados obtidos das plantas sadias e as plantas contaminadas com MSC, Declínio, Greening assintomática e Greening sintomática foram comparados entre si e comparados também aos pigmentos padrões descritos no item 4.3.

A figura 5.1 representa um espectro de emissão com excitação em $560 \mathrm{~nm}$ de padrões de clorofila $\boldsymbol{a}$, clorofila $\boldsymbol{b}$ e $\boldsymbol{\alpha}: \boldsymbol{\beta}$-caroteno diluídos em acetona. 


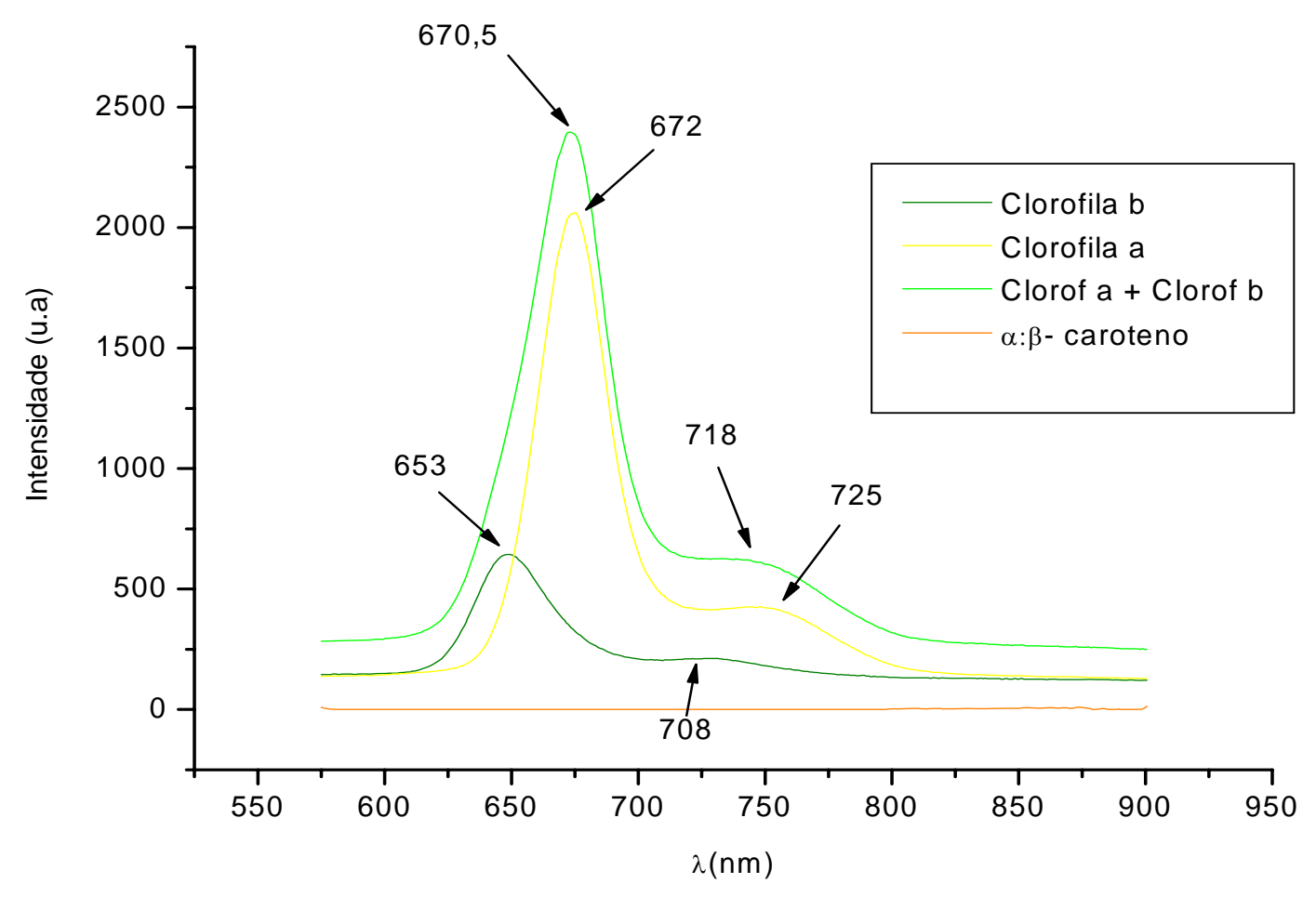

Figura 5.1 - Espectro de emissão de fluorescência com excitação em $560 \mathrm{~nm}$ de padrões de clorofila a, clorofila $\mathbf{b}$ e $\alpha: \beta$-caroteno diluído em acetona.

O espectro representado em verde claro da figura 5.1 refere-se à soma das clorofilas $\mathbf{a}$ e b que na mesma estão representadas em amarelo e verde escuro, respectivamente.

Analisando os espectros da figura 5.1 pode-se observar que, com a excitação em $560 \mathrm{~nm}$, há dois picos característicos referentes à clorofila b, 653 e $708 \mathrm{~nm}$, e dois picos característicos referentes à clorofila a, 672 e $725 \mathrm{~nm}$. Outro dado bastante relevante retirado desse gráfico é que o pigmento acessório $\boldsymbol{\alpha}: \boldsymbol{\beta}$-caroteno não emite fluorescência com a excitação em $560 \mathrm{~nm}$, e, portanto, não contribui para o diagnóstico das doenças. Estes espectros mostram bandas nas regiões de $670 \mathrm{~nm}$ (região do vermelho) comuns em extratos de plantas, concordando com trabalhos anteriores (Lichtenthaler et al., 1992a). 

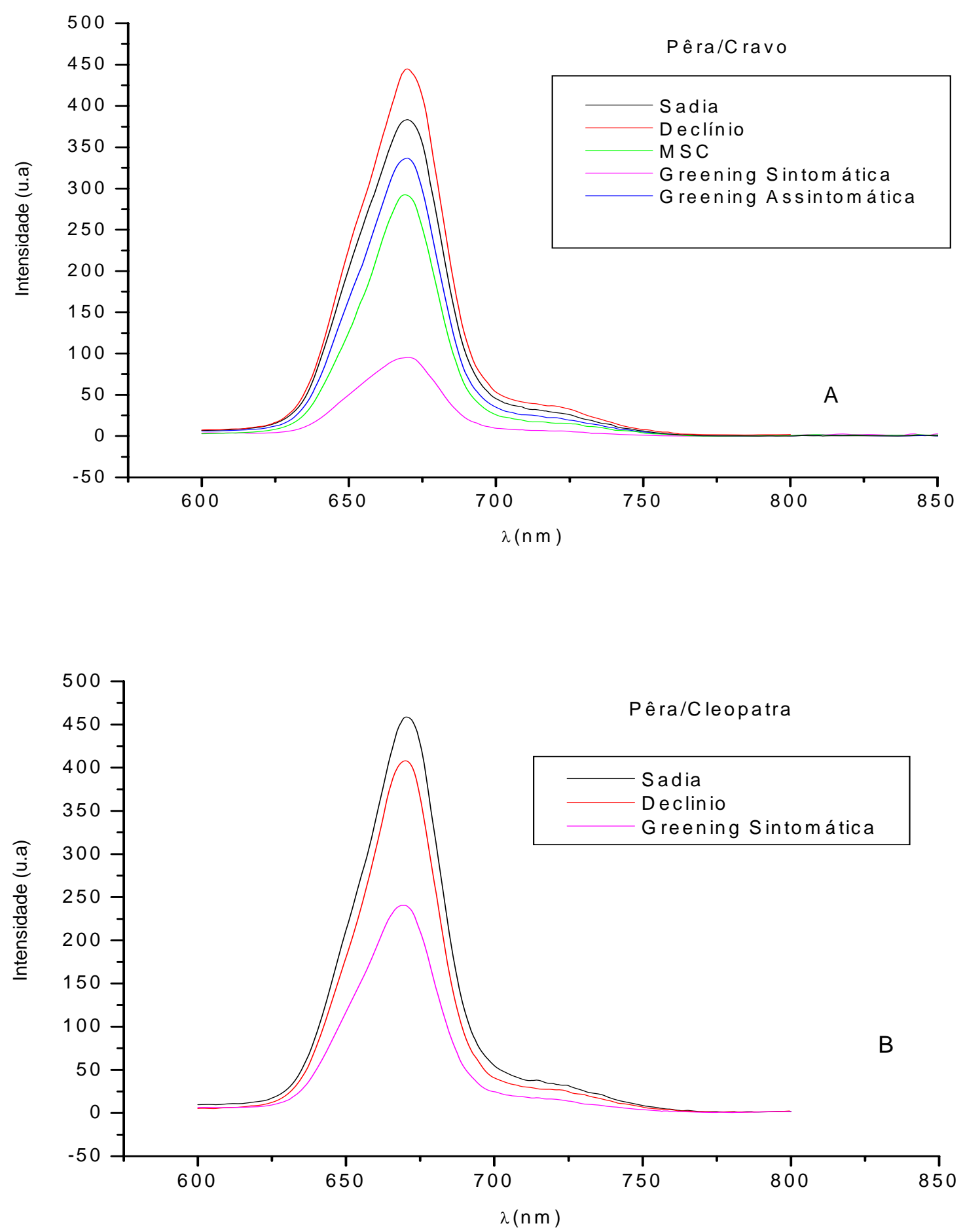

Figura 5.2 - Espectro de emissão de fluorescência com excitação em 560nm correspondente a diferentes tipos de extratos. a) Variedade Pêra com porta-enxerto limão Cravo e b) Variedade Pêra com porta-enxerto tangerina Cleópatra. 
Com o objetivo de identificar a contribuição que cada tipo de clorofila tem na formação das bandas de emissão dos extratos acima, procedeu-se a deconvolução dos espectros de fluorescência, em curvas de perfil gaussiano com a utilização do programa Pick Fit para cada curva do gráfico correspondente a figura 5.2.

As figuras 5.3 (a), (b), (c), (d) e (e) ilustram as cinco amostras analisadas de laranjeira Pêra em porta-enxerto de limoeiro Cravo em 2 linhas espectrais e 4 gaussianas. A primeira linha espectral é a linha de base, que corresponde ao espectro original a segunda linha espectral corresponde aos ajustes feitos a partir das 4 gaussianas e estas foram convenientemente ajustadas pelo programa. As letras a, b, c, d e e correspondem respectivamente as folhas sadias, Declínio, MSC, GS e GA. A figura 5.4 (a), (b), (c) ilustram as mesmas componentes analisadas em laranjeira Pêra com porta-enxerto limoeiro Cravo, analisadas para laranjeira Pêra enxertada em tangerina Cleópatra. As letras a, b e c são referentes às folhas sadias, MSC e Greening sintomática. Pode-se observar que o espectro resultante da soma das gaussianas mostrou um ajuste superior a 99,99\% com os espectros de emissão experimental.

As gaussianas componentes do espectro total são dependentes (se modificar um ponto todas as outras gaussianas serão modificadas) e representa a resposta tanto de um único tipo de estrutura fluorescente (um fluoróforo com diversos comprimentos de onda de fluorescência) quanto uma associação de diversos tipos de estruturas fluorescentes como as clorofilas, xantofilas, carotenóides entre outros. Nas tabelas de 5.1 a 5.5 pode-se observar a localização de cada gaussiana gerada, a intensidade do sinal assim como a variação de sua área em valor absoluto, a porcentagem correspondente e a razão entre os picos correspondentes da clorofila a em relação à clorofila $b$. 

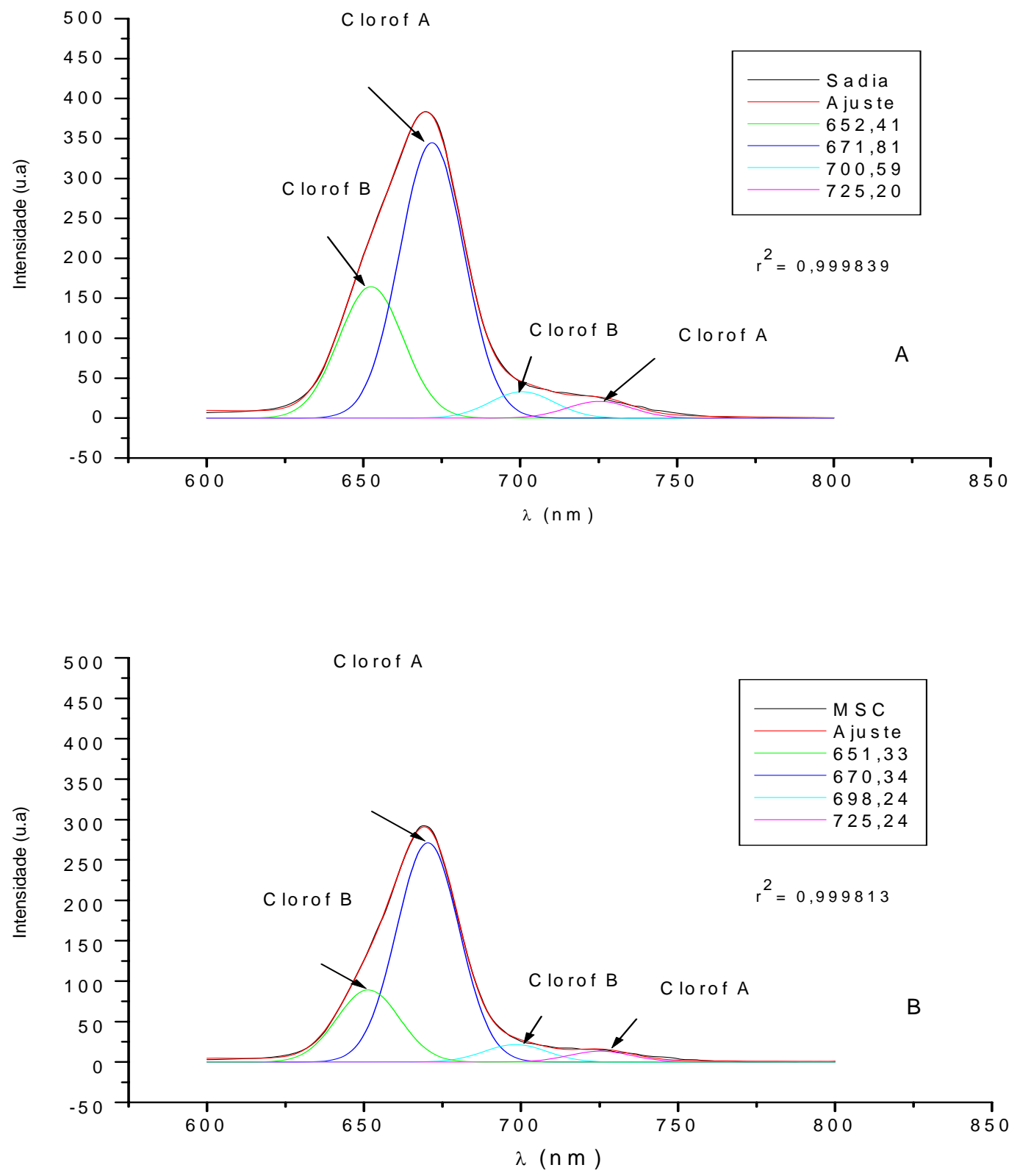

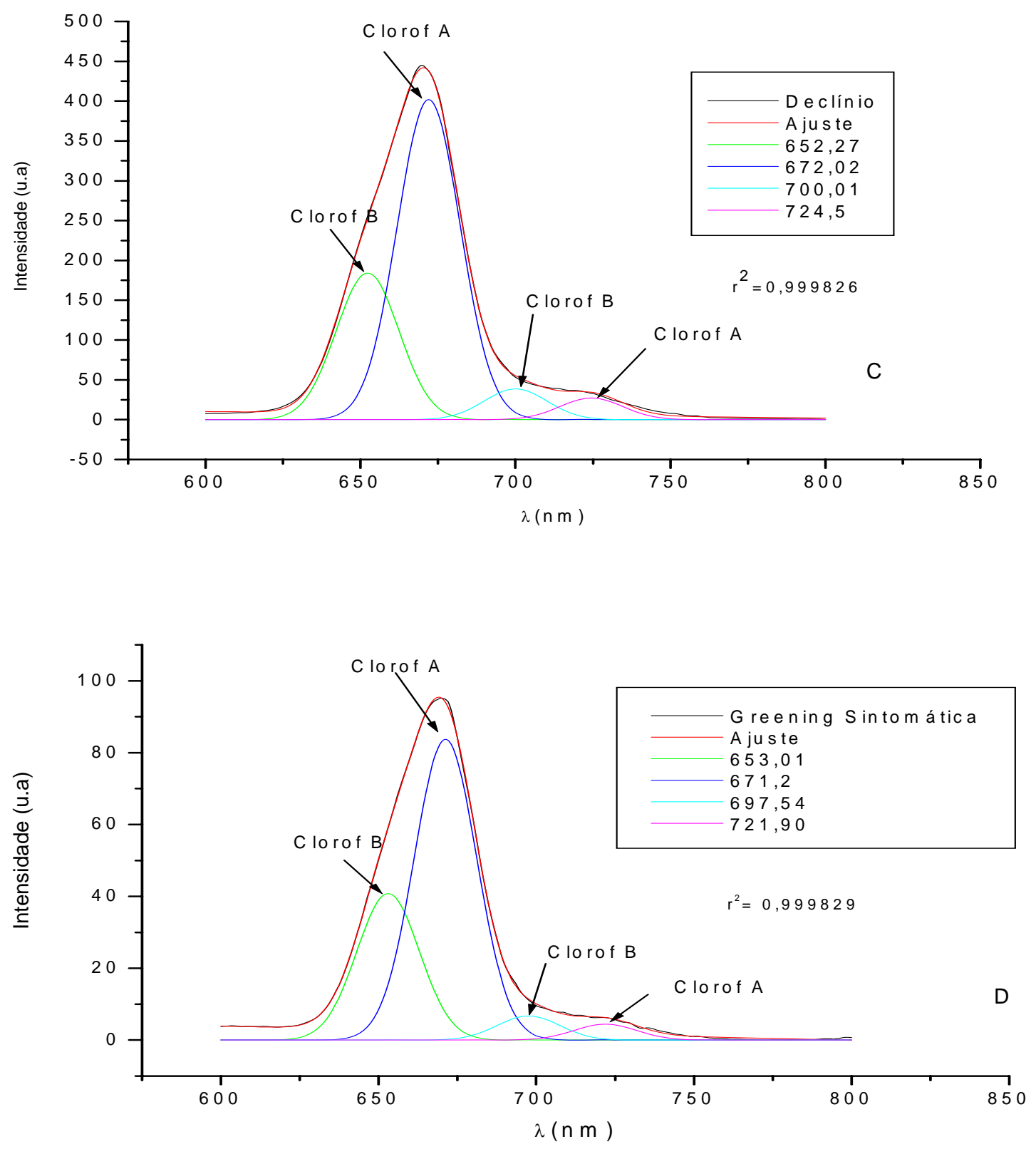


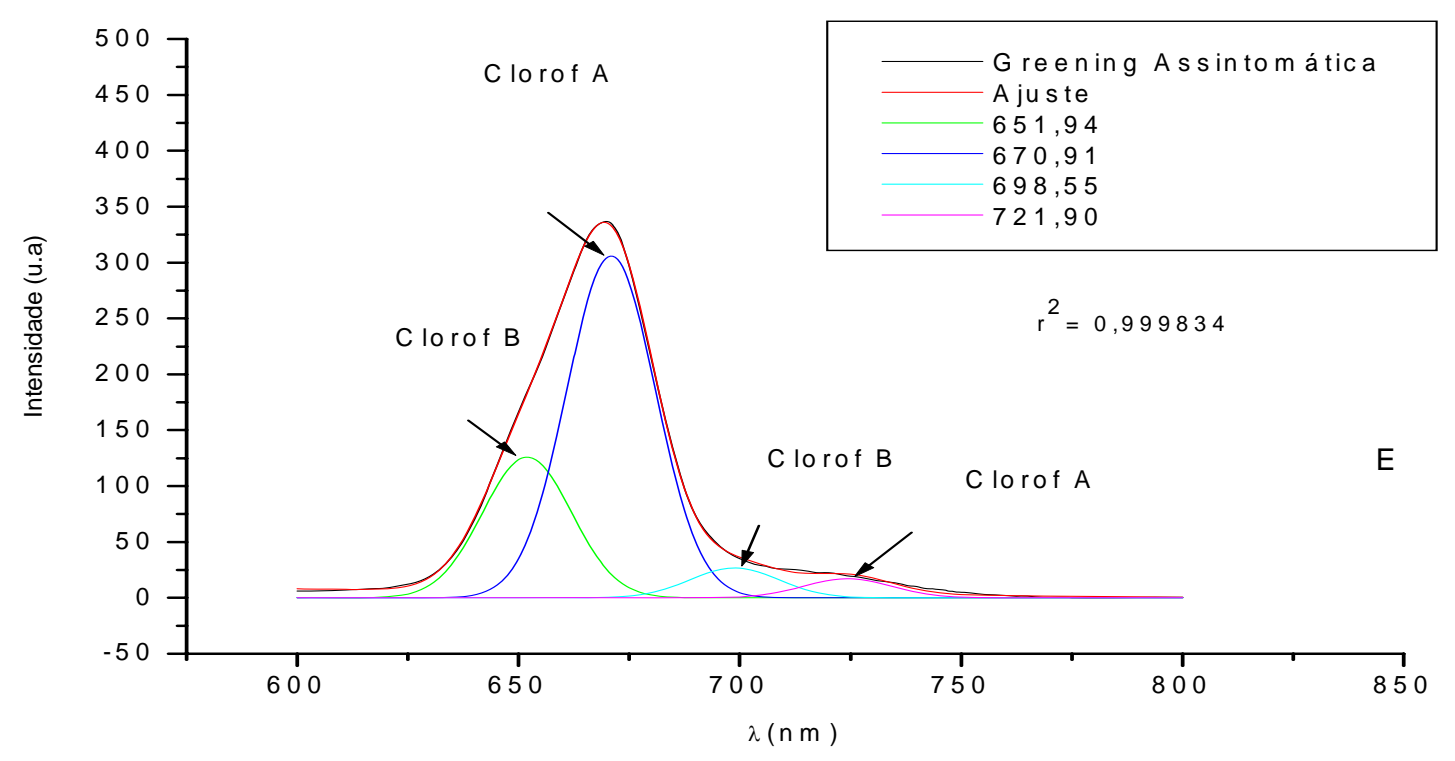

Figura 5.3 - Deconvolução dos espectros de emissão de Fluorescência com $\lambda_{\text {exc }}=560$ para os extratos de folhas de laranjeira Pêra com porta-enxerto de limão Cravo: a) sadia, b) MSC, c) Declínio, d) Greening sintomática, e) espectro de extrato Greening assintomática.

Analisando os dados e seus respectivos erros experimentais contidos nas tabelas de 5.1 a 5.5 pode-se observar que há nas plantas mais clorofila a comparada à clorofila b, essas observações obtidas experimentalmente condizem com os dados descritos na literatura (Streit et al.,2005).

Verificando a porcentagem das áreas obtidas pelas gaussianas (terceira coluna das tabelas) de folhas de laranjeira Pêra com porta-enxerto de limão Cravo, pode-se dizer que folhas de plantas contaminadas com Declínio apresentam uma maior quantidade de clorofila a e clorofila b, mesmo quando comparadas às folhas de plantas sadias. Já o que se observa nas demais doenças (MSC, GS e GA) é uma diminuição na porcentagem da área referente às duas clorofilas. As diminuições mais significativas nessas porcentagens das áreas ocorrem nas plantas contaminadas com Greening sintomática. 
Utilizando os dados percentuais da área, fez-se a razão entre a quantidade mais significativa de clorofila a (primeiro ponto, $\lambda \sim 671 \mathrm{~nm}$ ) em relação à quantidade mais significativa de clorofila $\mathbf{b}$ (segundo ponto, $\lambda \sim 651 \mathrm{~nm}$ ). Essas razões nos mostram valores distintos para cada doença, ou seja, MSC possui a maior razão clorofa/clorofb e essas razões diminuem gradualmente da MSC, GA, Declínio, sadia e GS respectivamente.

Esses dados nos levam a concluir que há uma diminuição mais significativa na quantidade percentual de área da clorofila $\mathbf{b}$ quando comparada à quantidade percentual de área de clorofila a. A partir dessas sutis, mas significativas variações de clorofila tornam-se possível a distinção das doenças.

Tabela 5.1 - Valores gerados pelas gaussianas através do programa Pick Fit para extratos de folhas sadias da variedade Pêra enxertada em limoeiro Cravo.

\begin{tabular}{|c|c|c|c|c|}
\hline Posição & Amplitude & Área & Área \% & $\begin{array}{c}\text { Razão } \\
\text { Clorof a/Clorof b }\end{array}$ \\
\cline { 1 - 3 } $652 \pm 0,2$ & $164 \pm 0,1$ & $4195 \pm 1$ & $27 \pm 0,01$ & \multirow{2}{*}{2,09} \\
$672 \pm 0,06$ & $383 \pm 0,4$ & $9776 \pm 16$ & $63 \pm 0,1$ & \multirow{2}{*}{} \\
\hline $701 \pm 0,4$ & $36 \pm 0,2$ & $925 \pm 4$ & $6 \pm 0,02$ & \\
\hline $725 \pm 0,4$ & $23 \pm 0,2$ & $589 \pm 6$ & $4 \pm 0,03$ & \\
\hline
\end{tabular}

Tabela 5.2 - Valores gerados pelas gaussianas através do programa Pick Fit para extratos de folhas com MSC da variedade Pêra enxertada em limoeiro Cravo.

\begin{tabular}{|c|c|c|c|c|}
\hline Posição & Amplitude & Área & Área \% & $\begin{array}{c}\text { Razão } \\
\text { Clorof a/Clorof b }\end{array}$ \\
\hline $651 \pm 0,2$ & $80 \pm 0,05$ & $2008 \pm 0,4$ & $21 \pm 0,01$ & \multirow{4}{*}{3,03} \\
\hline $670 \pm 0,06$ & $244 \pm 0,2$ & $6102 \pm 1$ & $60 \pm 0,04$ & \\
\hline $698 \pm 0,4$ & $19 \pm 0,1$ & $485 \pm 2$ & $5 \pm 0,01$ & \\
\hline $725 \pm 0,4$ & $12 \pm 0,1$ & $302 \pm 3$ & $3,1 \pm 0,01$ & \\
\hline
\end{tabular}


Tabela 5.3 - Valores gerados pelas gaussianas através do programa Pick Fit para extratos de folhas com Declínio variedade da Pêra enxertada em limoeiro Cravo.

\begin{tabular}{|l|l|l|l|c|}
\hline Posição & Amplitude & \multicolumn{1}{|c|}{ Área } & Área \% & $\begin{array}{c}\text { Razão } \\
\text { Clorof a/Clorof b }\end{array}$ \\
\cline { 1 - 4 } $652 \pm 1$ & $157 \pm 0,1$ & $3989 \pm 0,8$ & $26 \pm 0,05$ & \multirow{2}{*}{2,17} \\
\hline $671 \pm 1$ & $391 \pm 0,4$ & $9893 \pm 20$ & $64 \pm 0,04$ & \multirow{2}{*}{} \\
\hline $699 \pm 1$ & $35 \pm 0,2$ & $898 \pm 4$ & $6 \pm 0,01$ & \\
\hline $725 \pm 0,3$ & $24 \pm 0,2$ & $616 \pm 6$ & $4 \pm 0,01$ & \\
\hline
\end{tabular}

Tabela 5.4 - Valores gerados pelas gaussianas através do programa Pick Fit para extratos de folhas com Greening sintomática (GS) da variedade Pêra enxertada em limoeiro Cravo.

\begin{tabular}{|c|c|c|c|c|}
\hline Posição & Amplitude & Área & Área \% & $\begin{array}{c}\text { Razão } \\
\text { Clorof a/Clorof b }\end{array}$ \\
\hline $652 \pm 0,1$ & $64 \pm 0,8$ & $1588 \pm 6$ & $28 \pm 0,1$ & \multirow{2}{*}{2,05} \\
\hline $671 \pm 0,4$ & $101 \pm 0,8$ & $3778 \pm 92$ & $64 \pm 0,1$ & \\
\hline $697 \pm 0,1$ & $12 \pm 0,5$ & $309 \pm 6$ & $5,2 \pm 0,1$ & \\
\hline $722 \pm 0,4$ & $8 \pm 0,4$ & $200 \pm 14$ & $3,4 \pm 0,05$ & \\
\hline
\end{tabular}

Tabela 5.5 - Valores gerados pelas gaussianas através do programa Pick Fit para extratos de folhas com Greening assintomática (GA) da variedade Pêra enxertada em limoeiro Cravo.

\begin{tabular}{|c|c|c|c|c|}
\hline Posição & Amplitude & Área & Área \% & $\begin{array}{c}\text { Razão } \\
\text { Clorof a/Clorof b }\end{array}$ \\
\hline $652 \pm 0,1$ & $118 \pm 7$ & $2965 \pm 181$ & $25 \pm 7$ & \multirow{4}{*}{2,43} \\
\hline $671 \pm 0,4$ & $286 \pm 0,6$ & $7207 \pm 4$ & $61 \pm 6$ & \\
\hline $697 \pm 0,1$ & $25 \pm 2$ & $630 \pm 0,3$ & $5,3 \pm 0,4$ & \\
\hline $722 \pm 0,4$ & $16 \pm 0,2$ & $401 \pm 4$ & $3,3 \pm 0,5$ & \\
\hline
\end{tabular}

A figura 5.4 (a) e (b) ilustra os espectros obtidos dos extratos de folhas sadias e as contaminadas com Declínio, GS e da variedade Pêra com porta-enxerto de tangerina Cleópatra, respectivamente. 

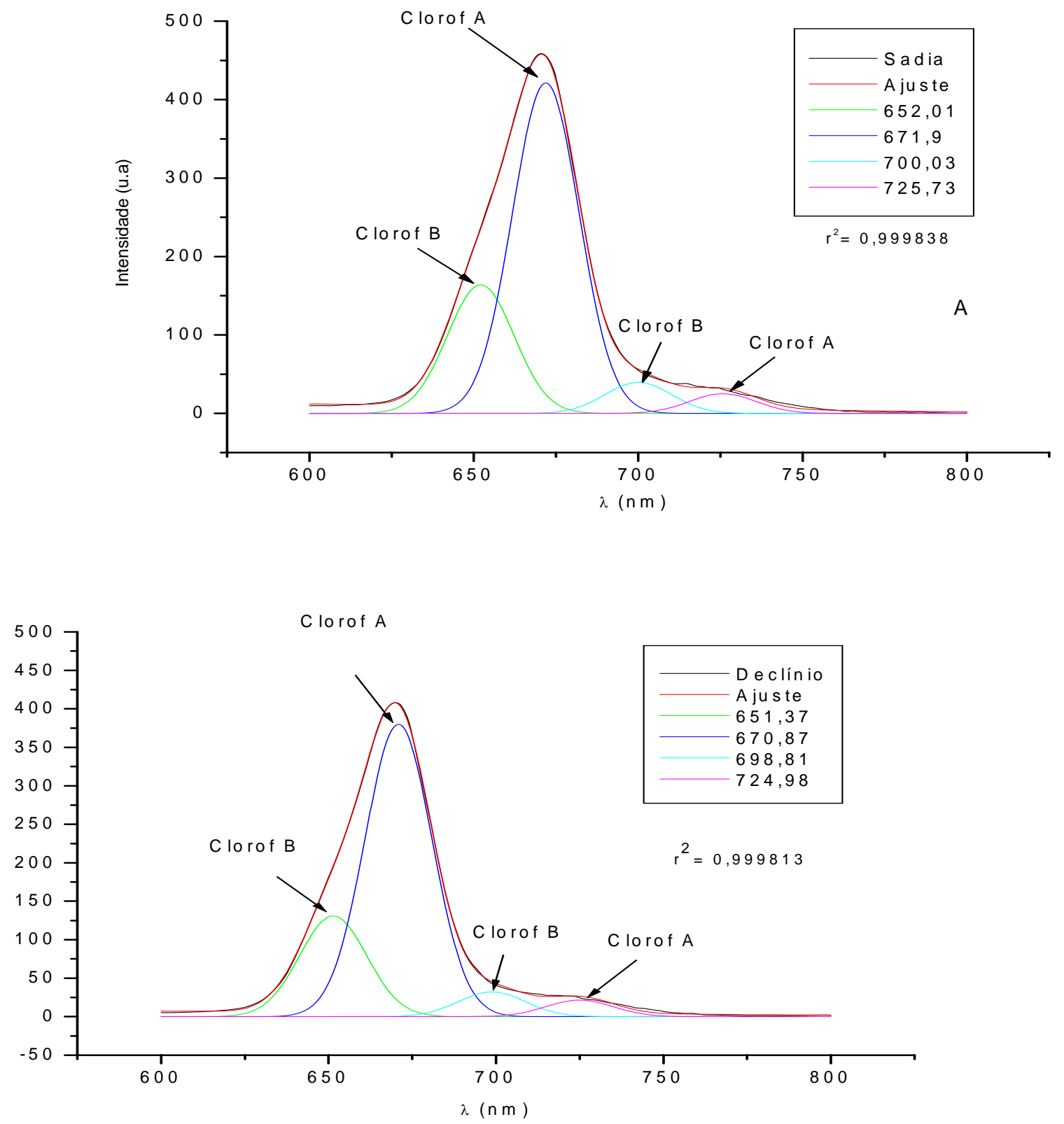


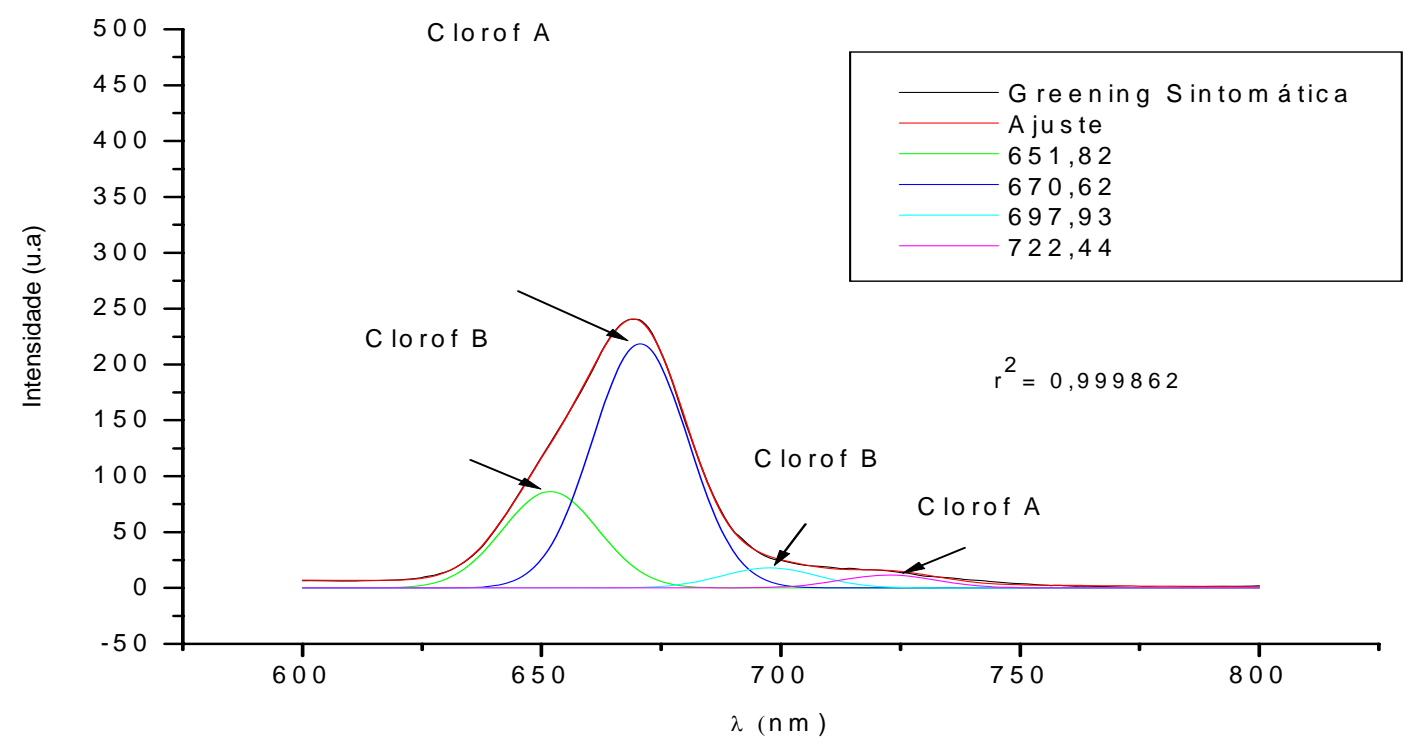

Figura 5.4 - Deconvolução dos espectros de emissão de Fluorescência com $\lambda_{\text {exc }}=560$ para os extratos de folhas de laranjeira Pêra com porta-enxerto de limão Cleópatra: a) sadia, b) Declínio, c) Greening assintomática.

As tabelas que seguem abaixo são referentes aos dados obtidos a partir da deconvolução de espectros de fluorescência, em curvas de perfil gaussiano com a utilização do programa Pick Fit (figura 5.4) para laranja da variedade Pêra com porta-enxerto de tangerina Cleópatra.

Tabela 5.6 - Valores gerados pelas gaussianas através do programa Pick Fit para extratos de folhas sadias da variedade Pêra enxertada em tangerina Cleópatra.

\begin{tabular}{|c|c|c|c|c|}
\hline Posição & Amplitude & Área & Área \% & $\begin{array}{c}\text { Razão } \\
\text { Clorof a/Clorof b }\end{array}$ \\
\cline { 1 - 4 } $652 \pm 0,2$ & $164 \pm 0,1$ & $4162 \pm 1$ & $26 \pm 0,01$ & \multirow{2}{*}{2,57} \\
\hline $672 \pm 0,06$ & $421 \pm 0,4$ & $10698 \pm 16$ & $65 \pm 0,1$ & \\
\hline $701 \pm 0,4$ & $40 \pm 0,2$ & $1004 \pm 4$ & $6,1 \pm 0,02$ & \\
\hline $725 \pm 0,4$ & $24 \pm 0,2$ & $638 \pm 6$ & $4 \pm 0,03$ & \\
\hline
\end{tabular}


Tabela 5.7 - Valores gerados pelas gaussianas através do programa Pick Fit para extratos de folhas com Declínio da variedade Pêra enxertada em tangerina Cleópatra.

\begin{tabular}{|c|c|c|c|c|}
\hline Posição & Amplitude & Área & Área \% & $\begin{array}{c}\text { Razão } \\
\text { Clorof a/Clorof b }\end{array}$ \\
\hline $652 \pm 1$ & $131 \pm 0,1$ & $3291 \pm 0,7$ & $23 \pm 0,05$ & \multirow{2}{*}{2,90} \\
\hline $671 \pm 1$ & $380 \pm 0,4$ & $9593 \pm 19$ & $67 \pm 0,04$ & \\
\hline $699 \pm 1$ & $32 \pm 0,2$ & $810 \pm 4$ & $6 \pm 0,01$ & \\
\hline $725 \pm 0,3$ & $21 \pm 0,2$ & $540 \pm 5$ & $4 \pm 0,01$ & \\
\hline
\end{tabular}

Tabela 5.8 - Valores gerados pelas gaussianas através do programa Pick Fit para extratos de folhas com Greening sintomática (GS) da variedade Pêra enxertada em tangerina Cleópatra.

\begin{tabular}{|c|c|c|c|c|}
\hline Posição & Amplitude & Área & Área \% & $\begin{array}{c}\text { Razão } \\
\text { Clorof a/Clorof b }\end{array}$ \\
\hline $652 \pm 0,1$ & $86 \pm 0,05$ & $2163 \pm 0,4$ & $26 \pm 1$ & \multirow{2}{*}{2,53} \\
\cline { 1 - 4 } $671 \pm 0,4$ & $218 \pm 0,2$ & $5474 \pm 11$ & $65 \pm 0,04$ & \multirow{2}{*}{$2,53,1$} \\
\hline $697 \pm 0,1$ & $18 \pm 0,1$ & $450 \pm 2$ & $5,4 \pm 0,1$ & \\
\hline $722 \pm 0,4$ & $12 \pm 0,1$ & $259 \pm 3$ & $3,5 \pm 0,1$ & \\
\hline
\end{tabular}

Várias informações podem ser extraídas das tabelas 5.1 a 5.8. A primeira é que o portaenxerto afeta a proporção entre as concentrações das clorofilas a e b. Folhas sadias da variedade Pêra em diferentes porta-enxertos não são quimicamente similares. As características de absorção de água e nutrientes do porta-enxertos são determinantes para a fisiologia da planta. O fator genético de a copa ser da mesma variedade parece ter uma importância secundária no que diz respeito à parte química das folhas. Outra informação relevante é que as doenças em geral afetam a intensidade da fluorescência das clorofilas. O Declínio aumenta em 17\% a intensidade de emissão da clorofila a, em contrapartida, as demais doenças causam redução da intensidade de emissão. A MSC reduz em torno de 21\%, o GS reduz em 76\% e o GA reduz em 11\%. Vários processos podem estar ocorrendo para que este resultado seja observado. As doenças poderiam gerar um processo de reação onde à planta desloca o equilíbrio dos processos fotoquímicos, tentando produzir um melhor aproveitamento da energia absorvida para processos de 
fotossíntese, diminuindo assim a eficiência dos processos de fluorescência. Ou então, as doenças teriam um impacto direto na concentração das clorofilas nas folhas. O terceiro e último resultado interessante observado pelos dados das tabelas 5.1 a 5.8, é que além da fluorescência como um todo ser alterada pelas doenças, existem deformações espectrais geradas pelas diferentes proporções entre as clorofilas a e b observadas para cada doença. A MSC, por exemplo, apresenta uma alta relação entre as intensidades de emissão das clorofilas a e b quando comparada com uma folha sadia. Já o GS, embora tenha intensidade de emissão $76 \%$ menor, apresenta relação entre clorofilas a e b muito similares ao de uma folha saudável. Vale a pena ressaltar também que, a GA embora em intensidade se assemelhe muito a uma folha saudável, em relação à forma espectral há uma grande diferença.

Outras técnicas de análises físicas e químicas poderiam ser utilizadas para avaliar mais precisamente todo o processo interno pelo qual a planta passa durante uma doença. Entretanto, este não é o foco deste trabalho. Este estudo com os extratos nos dá subsídios para justificar as alterações espectrais observadas nas folhas, que podem servir como metodologia de diagnóstico das doenças. Pelos resultados, as doenças afetam tanto a intensidade, quanto à forma espectral da emissão de fluorescência do conjunto das substâncias fotossintéticas das folhas de citros.

\subsection{DISTINÇÃO DE DOENÇAS DE CITROS}

Nesta seção serão apresentados e discutidos os dados obtidos como descritos no item 4 da seção Materiais e Métodos . Os espectros de emissão foram adquiridos no sistema portátil desenvolvido no LOLEIA, como descrito no subitem 4.1.1 desta mesma seção. Os resultados foram analisados através do método quimiométrico de PCA. 


\subsubsection{HAMLIN}

Na figura 5.5 são apresentados espectros típicos de laranja da variedade Hamlin com porta-enxerto de limão Cravo. O espectro referido é um espectro de emissão obtido pelo sistema portátil de fluorescência induzida por laser (FIL) em 561nm desenvolvido no LOLEIA.

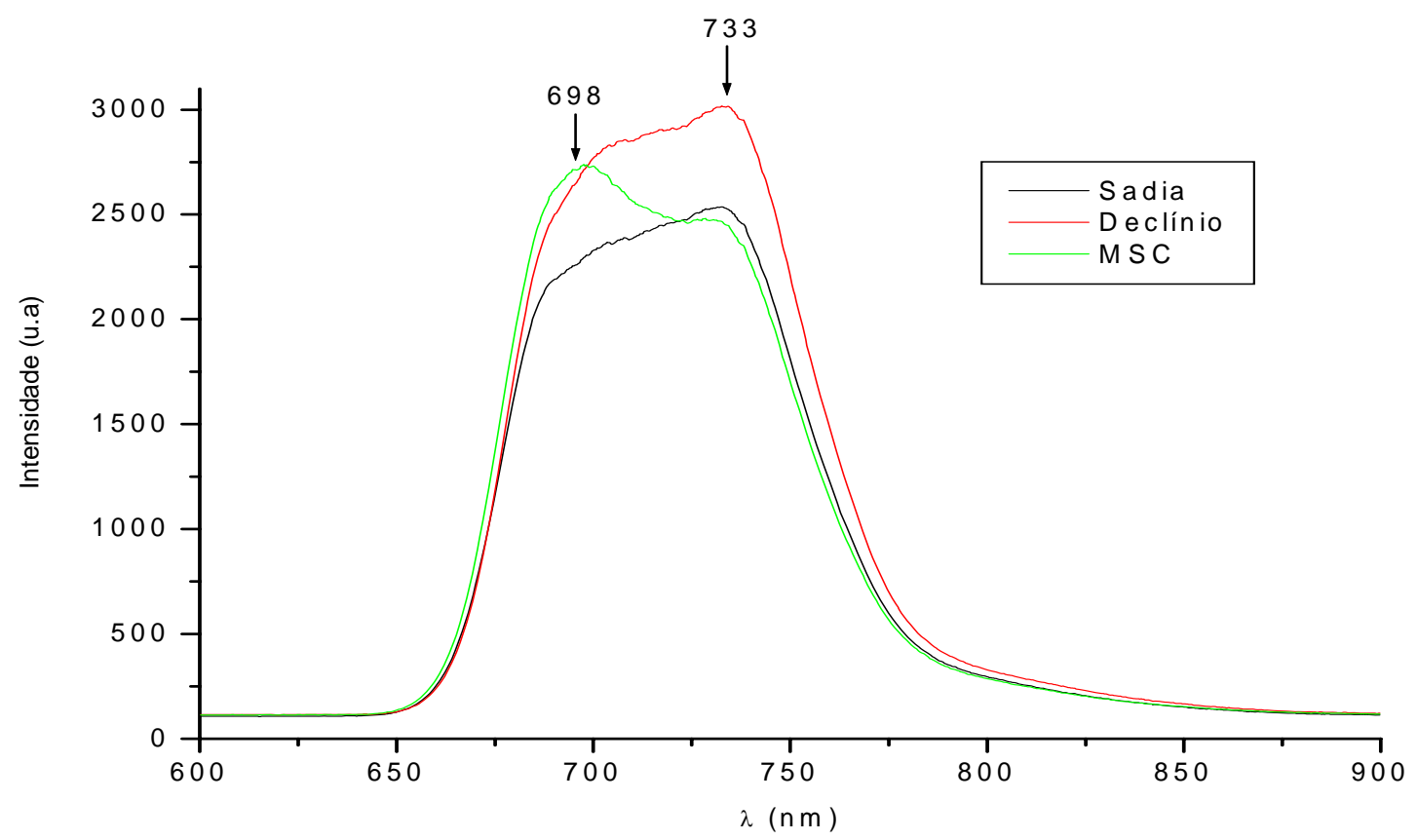

Figura 5.5 - Espectro típico de emissão de folhas de laranja Hamlin com porta-enxerto de limão Cravo, obtidos no sistema portátil de espectroscopia de fluorescência induzida por laser (FIL) desenvolvido e construído no LOLEIA.

O gráfico da figura 5.5 mostra picos em 698 e $733 \mathrm{~nm}$. Há um pequeno deslocamento e deformação quando comparado aos espectros provenientes dos extratos na seção 5.1 onde os picos são definidos em 670 e $718 \mathrm{~nm}$. Isto ocorre porque a fluorescência depende do meio, ou seja, em solução depende do solvente, e, já os espectros desta seção foram obtidos diretamente na folha. 
Analisando o gráfico é possível notar uma inversão entre os picos 698 nm e 733nm na amostra de Declínio quando comparada a MSC. O pico mais intenso da doença anteriormente referida ocorre no comprimento de onda de 733nm já nas amostras de MSC este pico encontra-se em 698nm.Os dados condizem com os descritos na literatura (Terêncio, 2006) que também observou essas mesmas inversões de picos.

Os dados espectrais foram analisados pelo método quimiometrico de PCA gerando um novo gráfico com três agrupamentos distintos (Figura 5.6). Esses agrupamentos são referentes às amostras sadias, com Declínio e MSC.

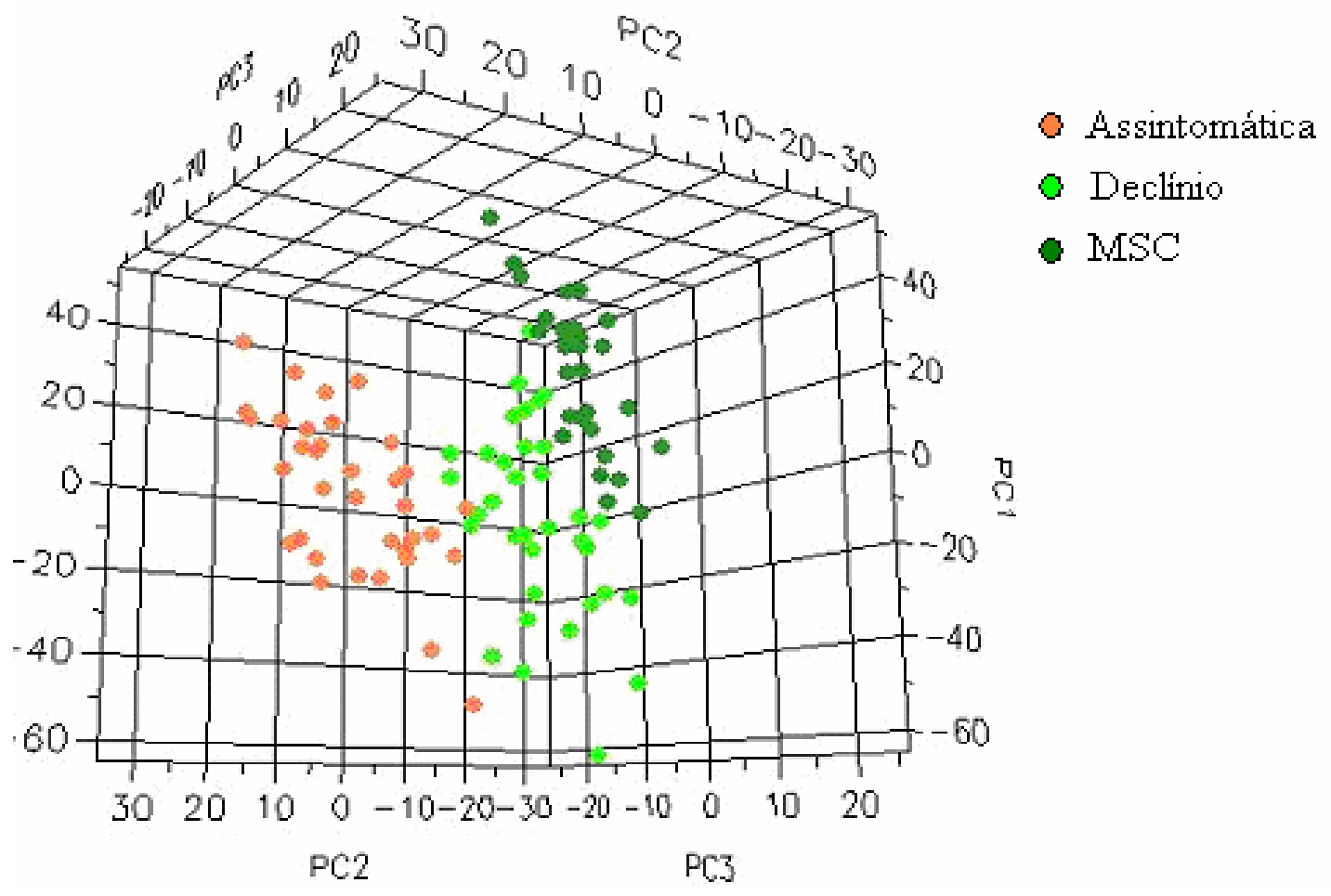

Figura 5.6 - Gráfico de PCA gerado através dos espectros de laranja Hamlin com porta-enxerto de limão Cravo contaminados com MSC, Declínio e plantas sadias, obtidos no sistema portátil de espectroscopia de fluorescência induzida por laser (FIL) desenvolvido e construído no LOLEIA 
O PCA gerado na figura 5.6 mostra três regiões bastante distintas onde os conjuntos de folhas com MSC encontram-se nas regiões de PC2 e PC3, folhas com Declínio estão concentradas na PC1 e PC3 já as folhas assintomática encontram-se totalmente localizadas na região da PC2. Com essa ferramenta quimiométrica foi possível distinguir as doenças, neste conjunto de amostras em $100 \%$.

O gráfico da figura 5.7, é também é um espectro típico obtido no sistema portátil com laser em 561nm. Esse conjunto de amostras possui plantas sadias, GA e GS, MSC e Declínio.

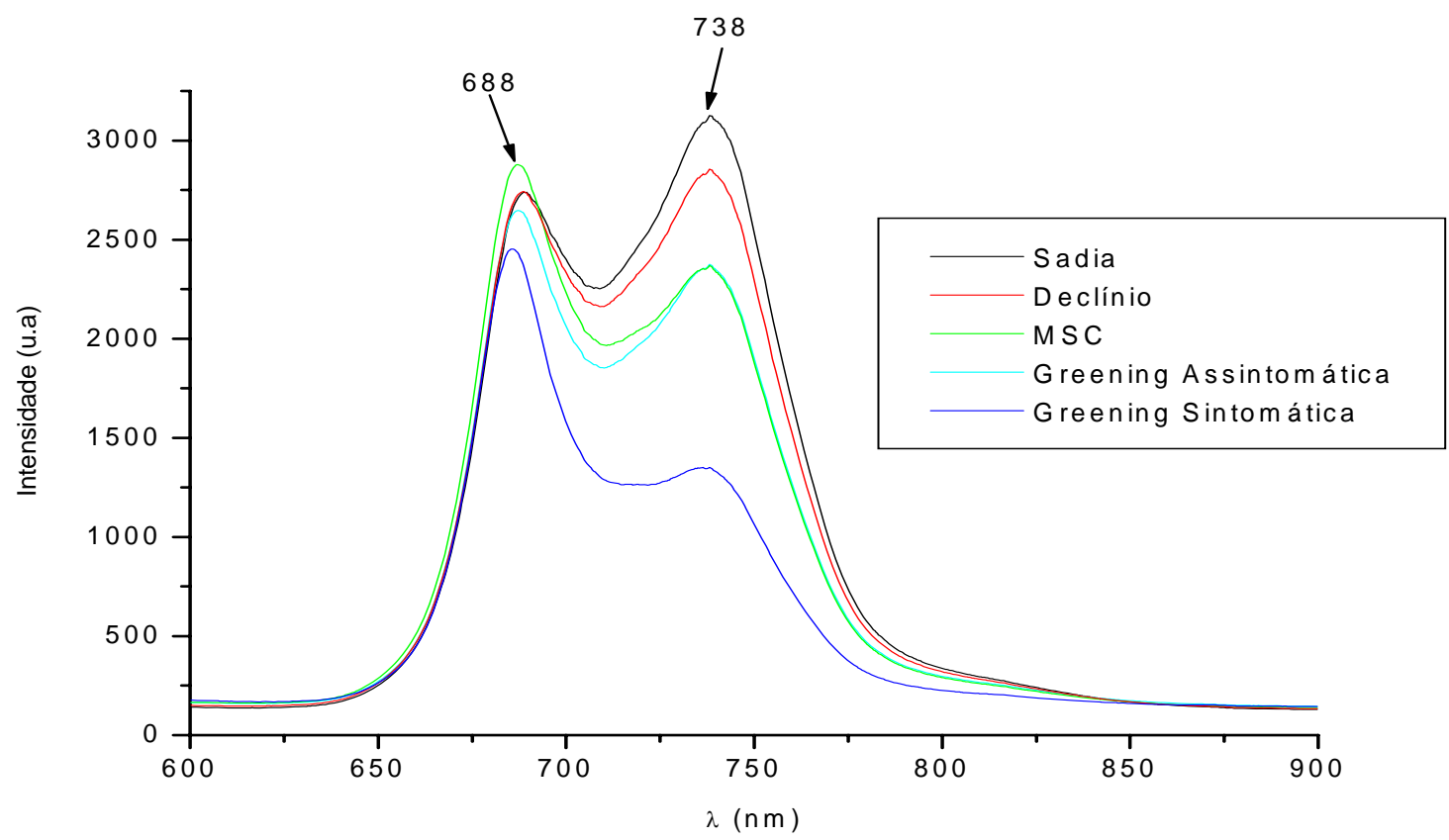

Figura 5.7 - Espectros típicos de emissão de fluorescência de folhas de laranja Hamlin em portaenxerto de limão Cravo coletadas na estação de chuva, obtidos no sistema portátil FIL desenvolvido e construído no LOLEIA.

Uma informação importante pôde ser extraída ao comparar os gráficos da figuras 5.6 e 5.7. A época do ano para análises é um fator relevante. Estações chuvas geram espectros mais bem definidos. Outra informação importante é que mesmo se sendo plantas com a mesma variedade e o mesmo porta-enxerto há um sutil deslocamento nos picos mais intensos, 698 e 
$733 \mathrm{~nm}$ para 688 e $738 \mathrm{~nm}$. Esse sutil deslocamento já era previsto por Lange et al., 1991 e Johnson et al., 2000 onde afirmavam que as intensidades das bandas poderiam variar dentro de uma mesma planta e entre uma mesma espécie dependendo das condições ambientais.

Com os dados que geraram a figura 5.7 foram feitas análises de PCA para melhor separação das doenças, como mostra a figura 5.8.

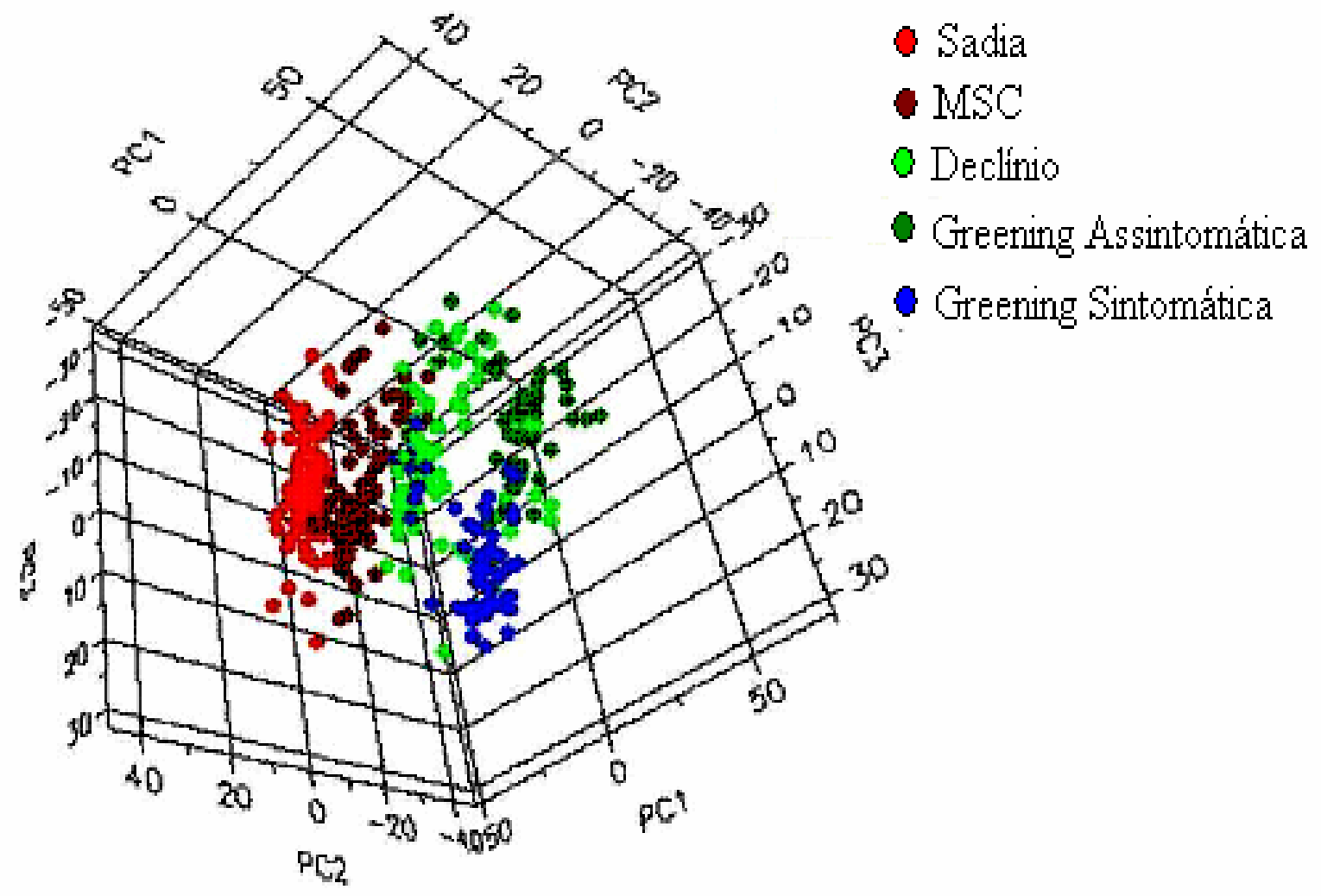

Figura 5.8 - Gráfico de PCA gerado através dos espectros de emissão de fluorescência de folhas de laranjeira Hamlin em porta-enxerto de limão Cravo coletada na estação de chuva, obtidos no sistema portátil de FIL desenvolvido e construído no LOLEIA em plantas contaminadas com GA, GS, MSC, Declínio e plantas sadias.

Analisando partes distintas do gráfico pode-se notar que com exceção a MSC todas as outras doenças são possíveis serem separadas $100 \%$ da das amostras sadias. O resultado mais importante obtido neste PCA é que a técnica espectroscópica associada à quimiometria torna-se 
possível à distinção entre a GA e a GS com uma precisão superior a 95\%. Este é um resultado extremamente importante, pois quando se compara à técnica de PCR esta possui uma capacidade apenas 56\% no diagnóstico da doença (Wulff et al., 2006). Com isso pode-se dizer que a metodologia proposta é capaz de diagnosticar as várias doenças estudadas.

As informações extraídas da figura 5.8 corroboram com os resultados obtidos na seção 5.1 de Extratos Fotossintéticos, visto que as alterações na quantidade de clorofila a e b torna-se possível uma excelente distinção das doenças mesmo essas tendo níveis de severidade diferentes como no caso da GA e GS.

\subsubsection{VALÊNCIA}

A variedade Valência é bastante utilizada na citricultura brasileira e por isso foi um dos alvos do nosso estudo (Gimenes-Fernandes et al., 2002). O conjunto de amostras abaixo se refere à variedade Valência enxertada em limão Cravo. A figura 5.9 representa um gráfíco típico obtido através do sistema portátil FIL. 


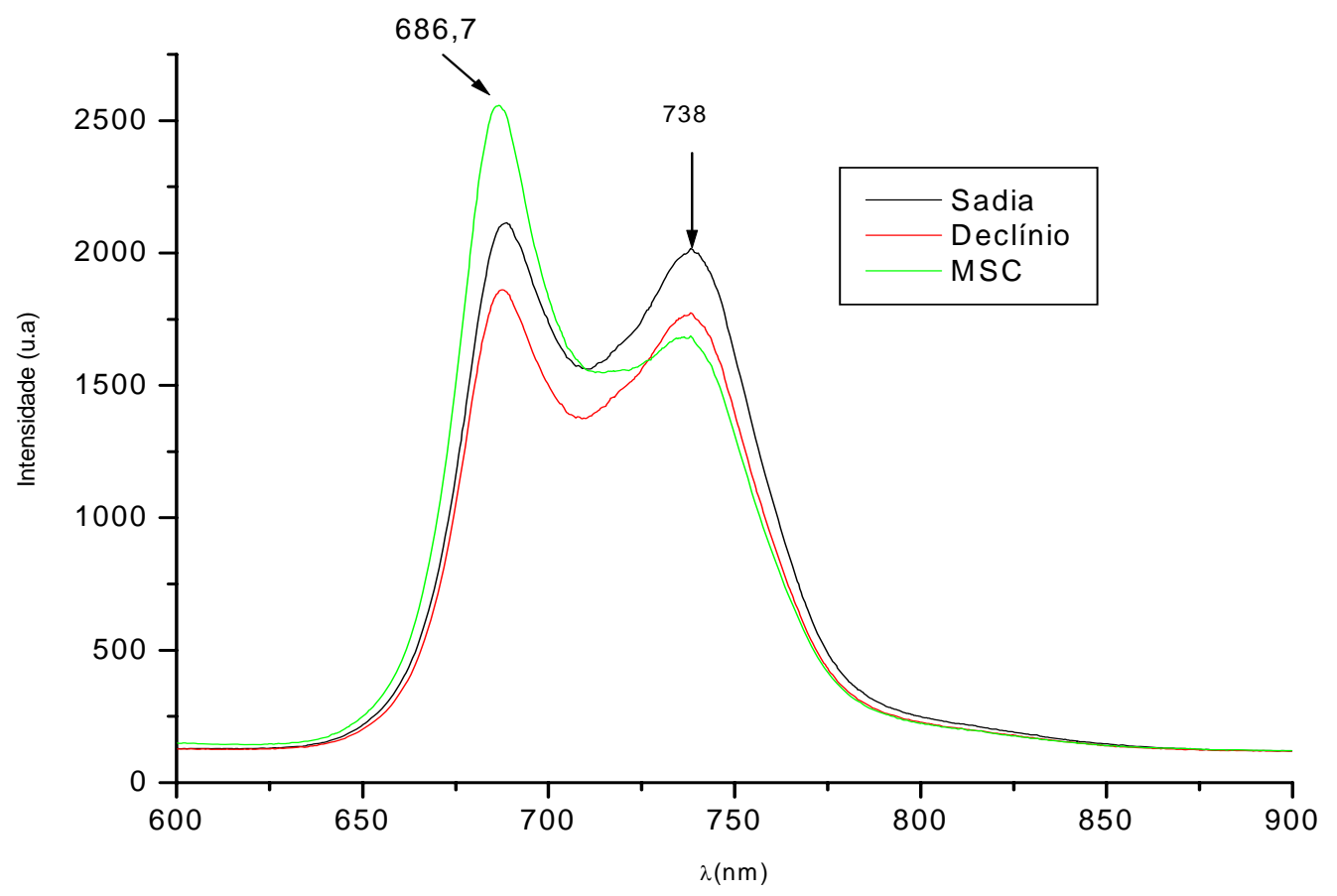

Figura 5.9 - Espectro típico de emissão de fluorescência de folhas de laranjeira Valência com em porta-enxerto de limão Cravo coletadas em época de seca, obtidos através do sistema portátil de FIL desenvolvido e construído no LOLEIA.

A figura 5.9 nos mostra que o pico $686,7 \mathrm{~nm}$ é mais intenso que o pico $738 \mathrm{~nm}$ para as amostras de MSC. Já para as amostras com Declínio e sadia esses picos encontram-se praticamente na mesma altura, apenas a intensidade do sinal como um todo se altera, ou seja, pode-se dizer que as diferentes variedades das plantas sofrem alterações diferentes nos teores de clorofila a e b.

Estudo quimiomérico foi feito com o conjunto de amostras que deu origem à figura 5.9, esses dados geraram um PCA que esta representada na figura 5.10. 


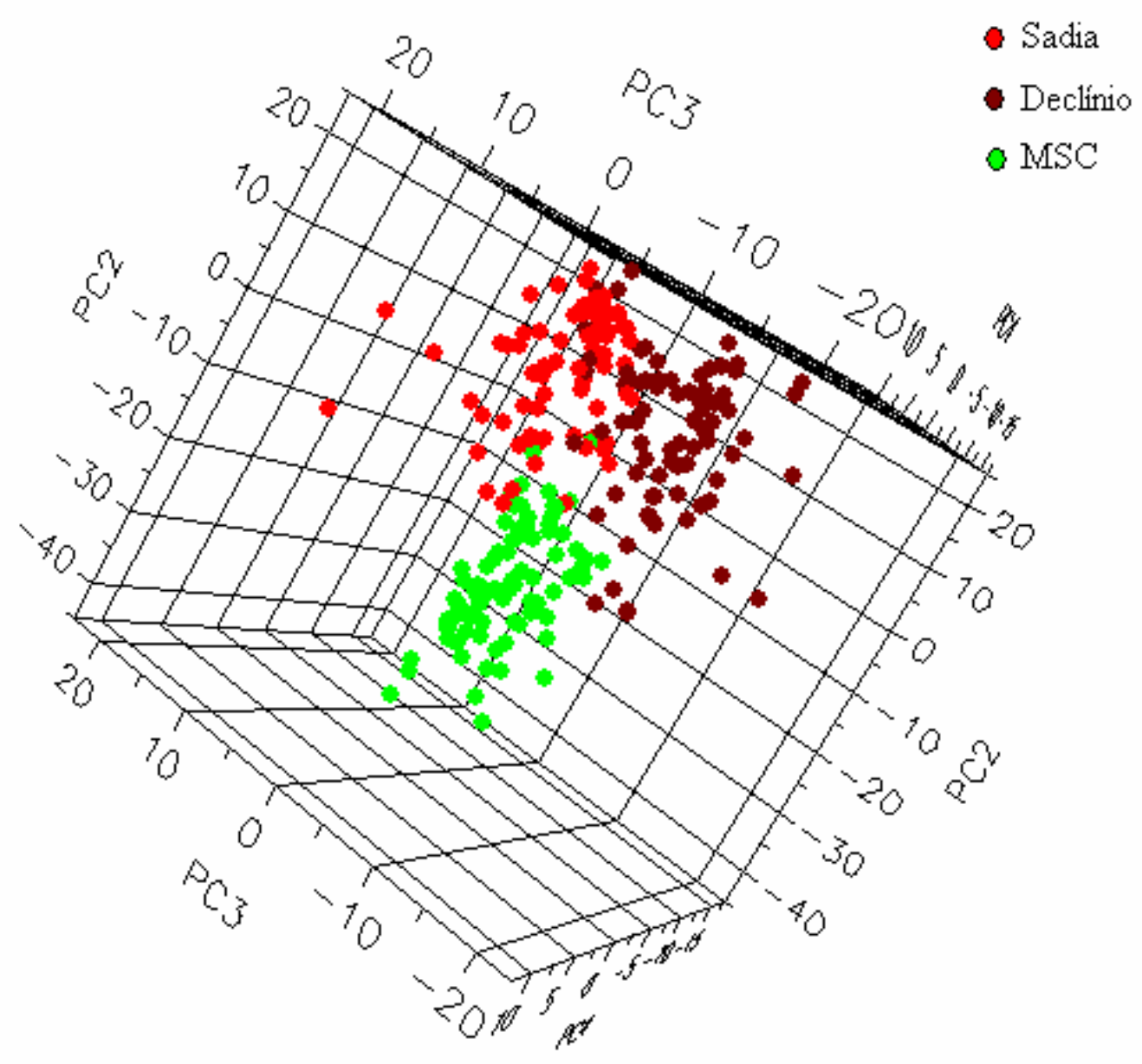

Figura 5.10 - Gráfico de PCA gerado através dos espectros de emissão de fluorescência de folhas de laranjeira Valencia em porta-enxerto de limão Cravo coletadas em época de seca, obtido através do sistema portátil de FIL desenvolvido e construído no LOLEIA em plantas contaminadas com MSC, Declínio e plantas sadias.

Os dados de PCA do gráfico da figura 5.10 mostram uma separação, mesmo que não em todos os casos, das amostras analisadas. Há uma formação de agrupamentos podendo diferenciar folhas com MSC e Declínio e também essas duas doenças de folhas sadias com uma taxa precisão de $93 \%$.

O espectro abaixo (figura 5.11) corresponde a um lote de amostras que possuem folhas de árvores sadias, MSC, Declínio, GA e GS. 


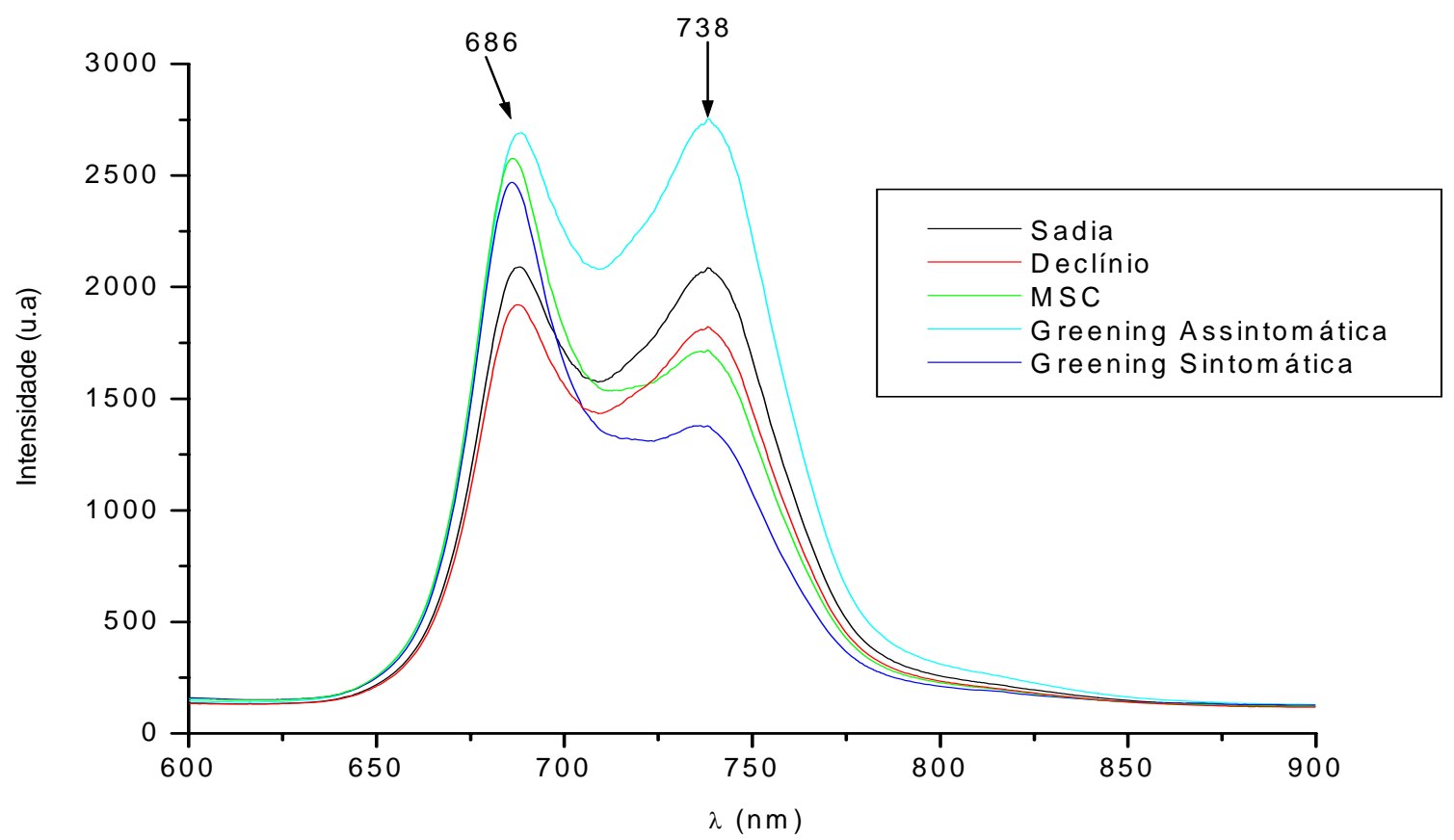

Figura 5.11 - Espectros típicos de emissão de folhas de laranjeira Valência em porta-enxerto de limão Cravo coletadas em estação chuvosa, obtidos através do sistema portátil FIL desenvolvido e construído no LOLEIA.

As amostras analisadas nesse conjunto foram coletadas no verão, diferente do conjunto anterior. Para esta variedade, o regime hídrico parece não afetar muito o perfil do espectro.

A PCA dessas amostras, mostrado na figura 5.12, trouxe uma informação bastante interessante: partes das folhas consideradas sadias estão em meio das amostras com Declínio, isto pode ser um indício da precocidade de diagnóstico da doença pela técnica. 


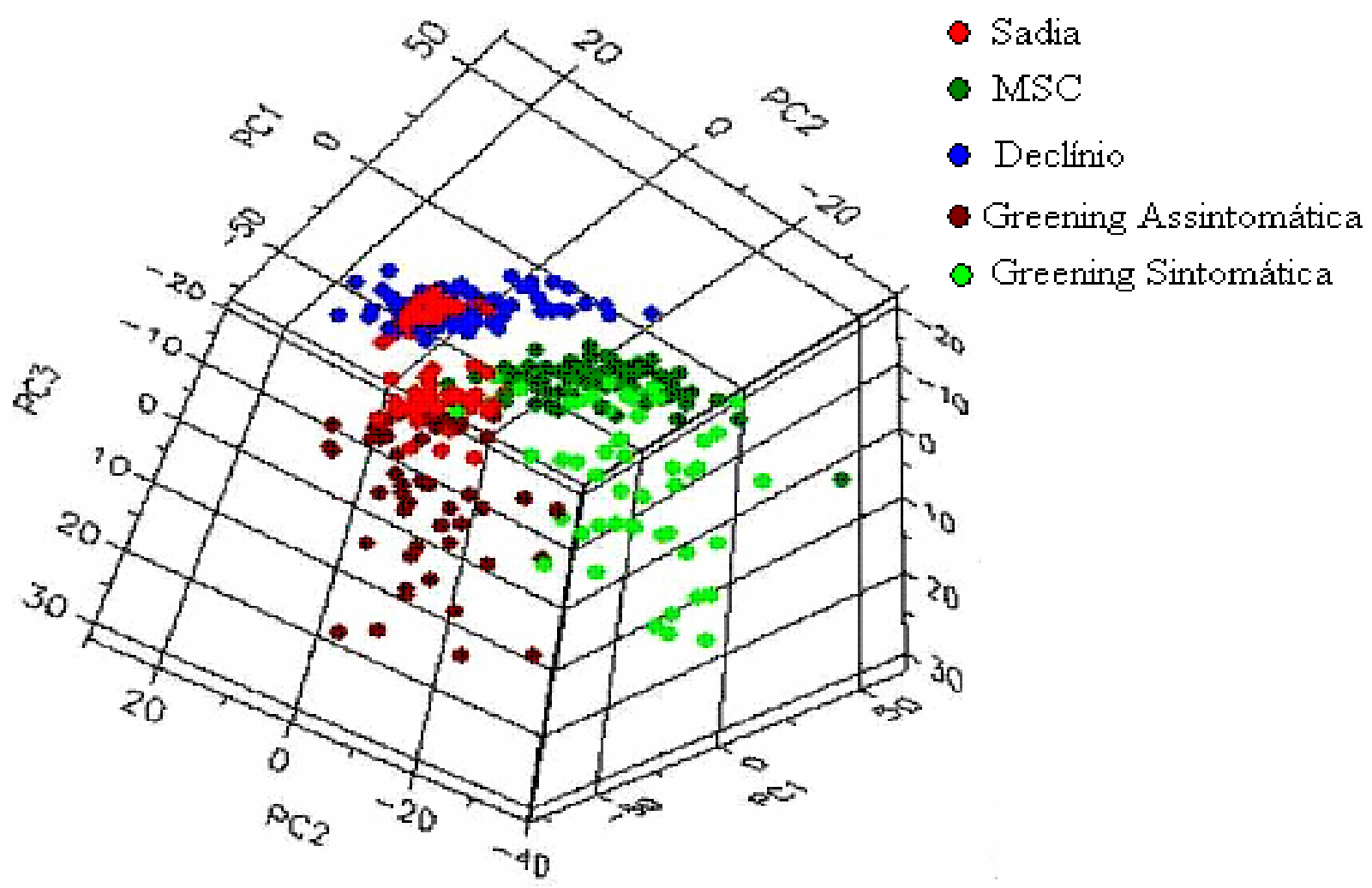

Figura 5.12 - Gráfico de PCA gerado através dos espectros de folhas de laranjeira Valência em porta-enxerto de limão Cravo coletadas em estação chuvosa, obtido através do sistema portátil FIL desenvolvido e construído no LOLEIA em plantas contaminadas com GA, GS, MSC, Declínio e plantas sadias.

\subsubsection{PÊRA}

Os gráficos apresentados abaixo são referentes à laranjeira Pêra enxertada em limoeiro Cravo. As figuras 5.13 a 5.16 estão relacionadas aos espectros obtidos pelo sistema portátil do LOLEIA. Na figura 5.13 pode-se observar três diferentes formas de espectro onde caracteriza três diferentes amostras, MSC, Declínio e sadia. 


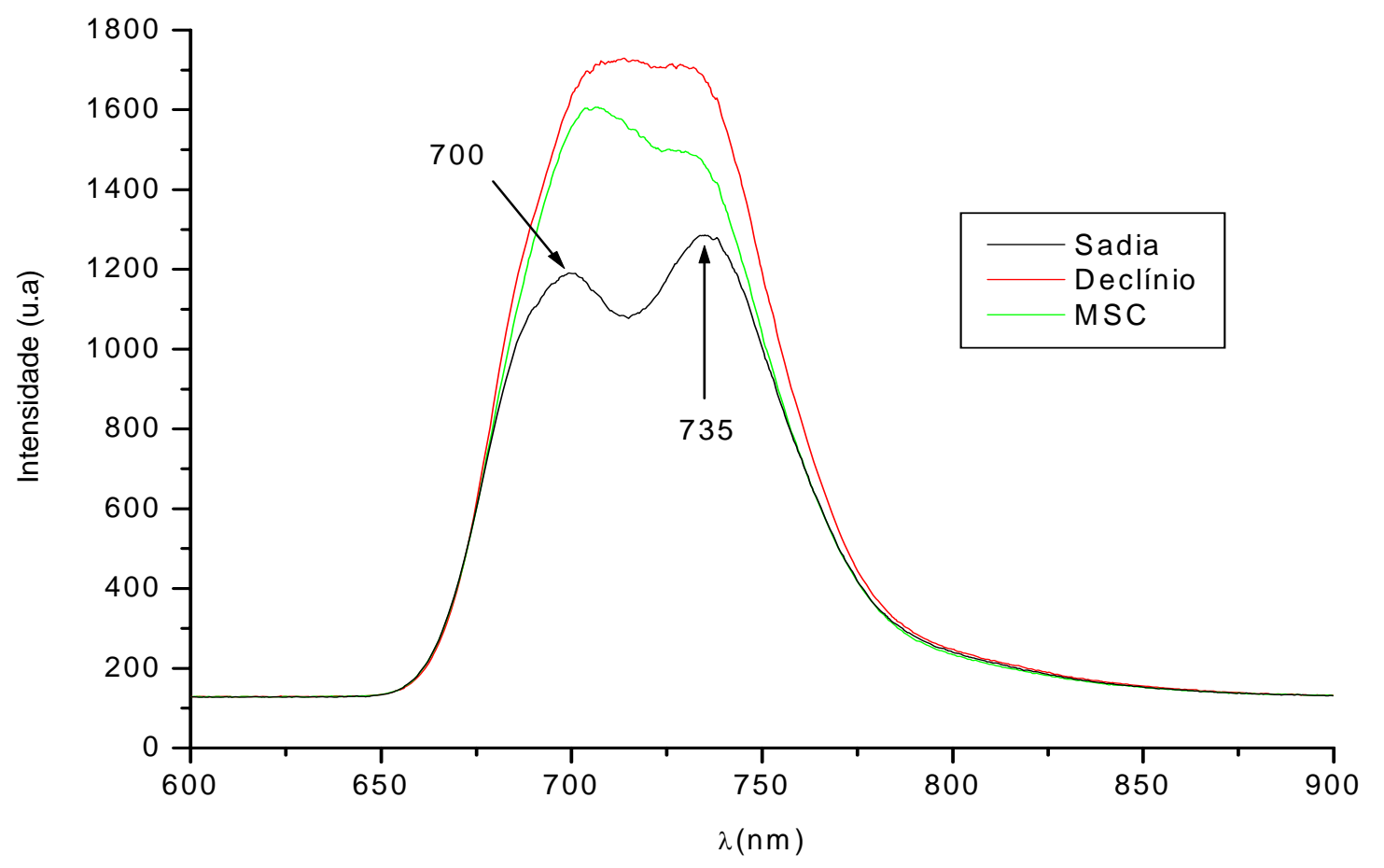

Figura 5.13 - Espectro típico de emissão de fluorescência de folhas de laranjeira Pêra em portaenxerto de limão Cravo coletadas em estação de seca, obtido através sistema portátil desenvolvido e construído no LOLEIA.

O espectro da amostra sadia possui uma inversão de máximos se comparada às amostras com MSC e Declínio. O espectro do Declínio possui um máximo extremamente sutil, mas mesmo assim, é possível extrair grandes informações como é o caso do gráfico da figura abaixo (figura 5.14) esta relacionada com a análise de PCA das amostras. 


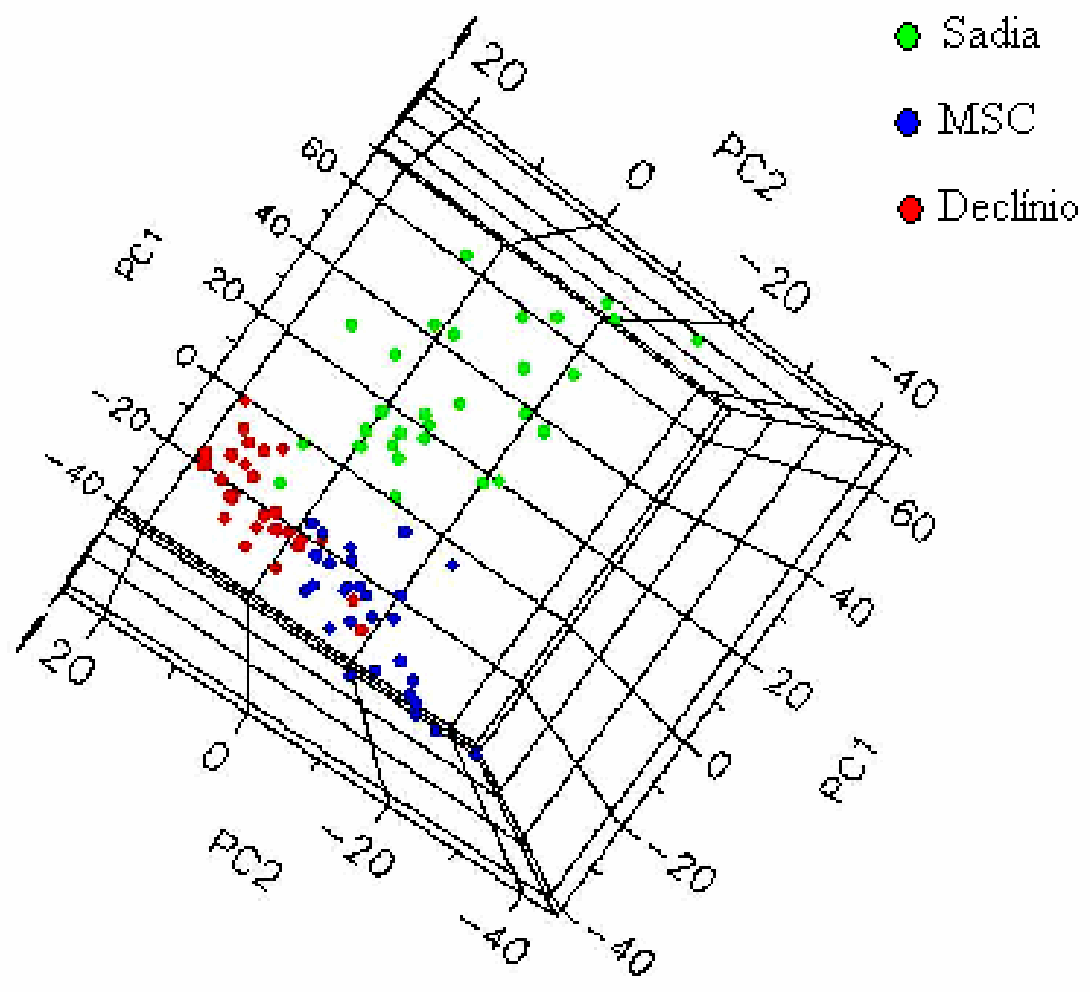

Figura 5.14 - Gráfico de PCA gerado através dos espectros de folhas de laranjeira Pêra em portaenxerto de limão Cravo coletadas em estação de seca, obtido através do sistema portátil FIL desenvolvido e construído no LOLEIA em plantas contaminadas com MSC, Declínio e plantas sadias.

O Gráfico de PCA deixa claro que é possível diferenciar as doenças em 100\% dos casos quando comparadas a amostras sadias e $98 \%$ no geral. 


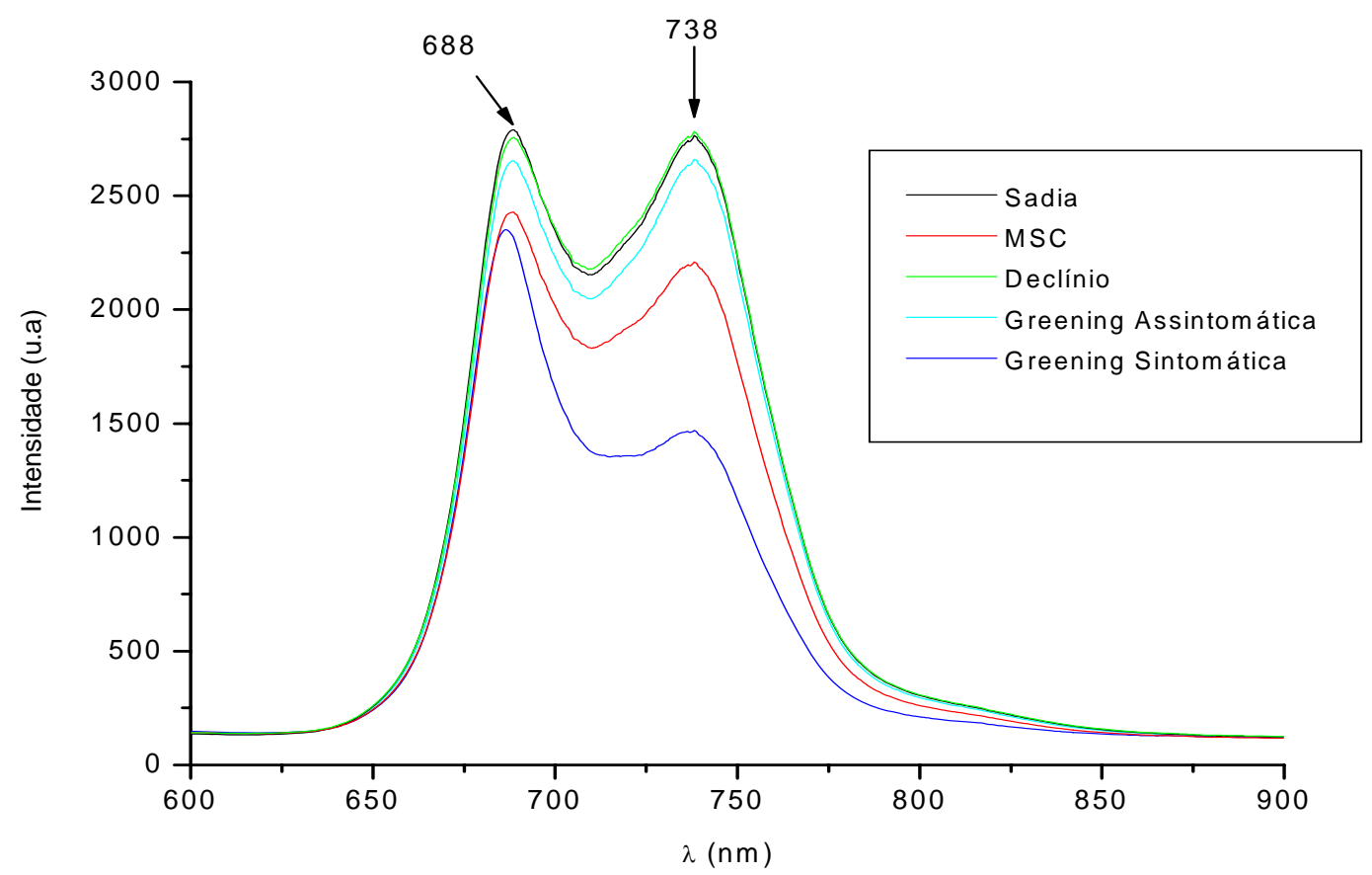

Figura 5.15 - Espectro típico de emissão de fluorescência de folhas de laranjeira Pêra em portaenxerto de limão Cravo coletadas em estação chuvosa, obtido através sistema portátil desenvolvido e construído no LOLEIA.

A partir do gráfico espectroscópico típico das doenças é possível observar que os sinais dos picos possuem a mesma altura, apenas no Greening Sintomática que há uma diferença, pois o pico em $688 \mathrm{~nm}$ é mais alto que o $738 \mathrm{~nm}$. Os outros espectros diferem em intensidade de sinal. Com esses mesmos dados foi feito um gráfico de PCA (Figura 5.16). 


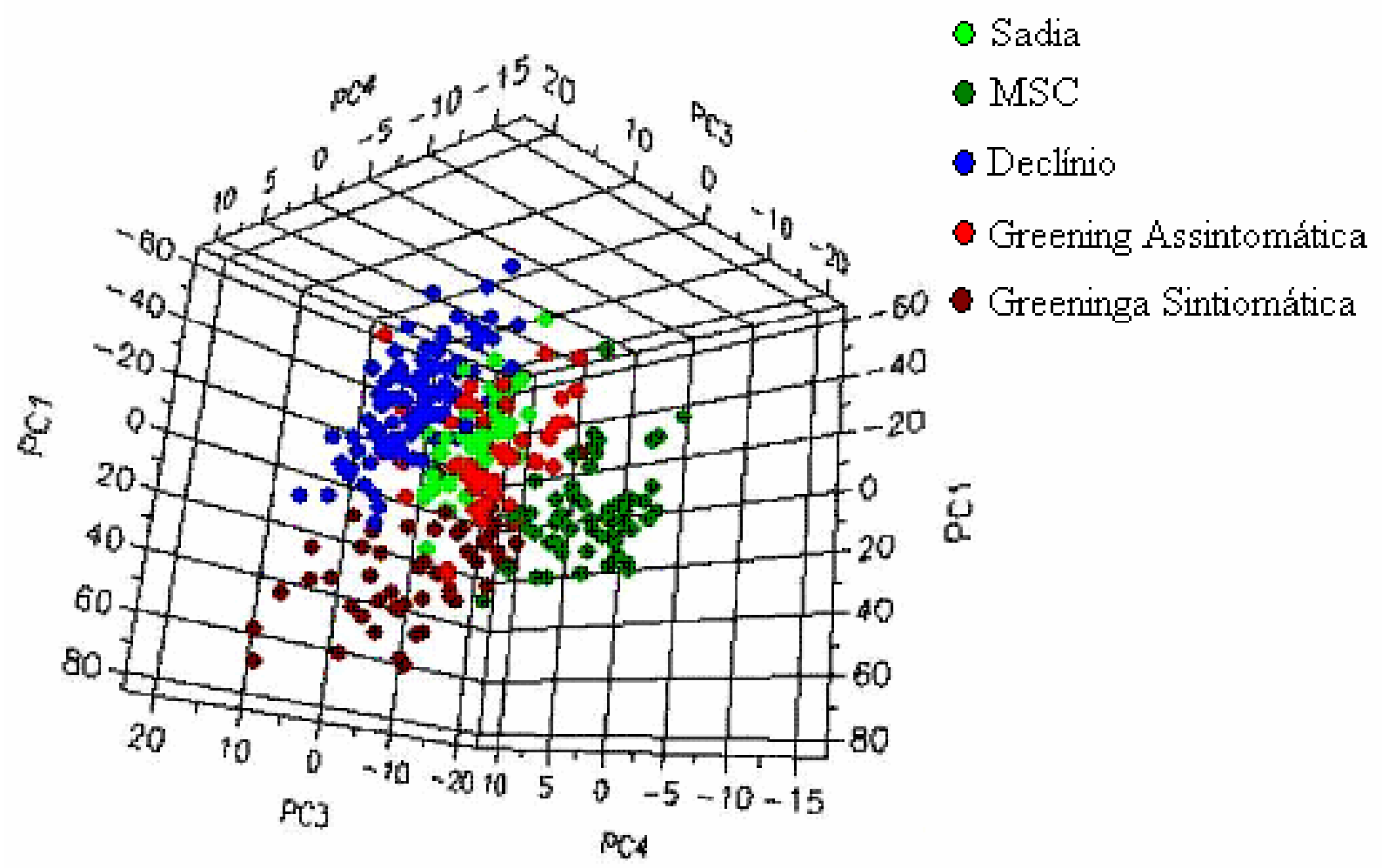

Figura 5.16 - Gráfico de PCA gerado através dos espectros de folhas de laranjeira Pêra em portaenxerto de limão Cravo coletadas em estação de chuva, obtido através do sistema portátil FIL desenvolvido e construído no LOLEIA em plantas contaminadas com GA, GS, MSC, Declínio e plantas sadias.

Analisando o gráfico da Figura 5.16 é possível distinguir em 100\% as amotras de MSC quando comparadas às amostras sadias. Uma separação com uma porcentagem também alta é observada entre as amostras de Declínio e sadias. Uma observação interessante é que as amostras consideradas sadias pelos técnicos mostraram uma sobreposição com a área determinada pelo GA, como esta não possui sintomas característicos, é possível que as amostras sadias já possam estar contaminadas. Este também pode ser um indício de precocidade no diagnóstico.

Outro porta-enxerto foi analisado para a variedade Pêra: a tangerina Sunki. Para este conjunto foram analisadas amostras de folhas sadias, com GA e GS (Figura 5.17) as amostras aqui estudadas provieram de uma fazenda irrigada por sistema de gotejamento. 


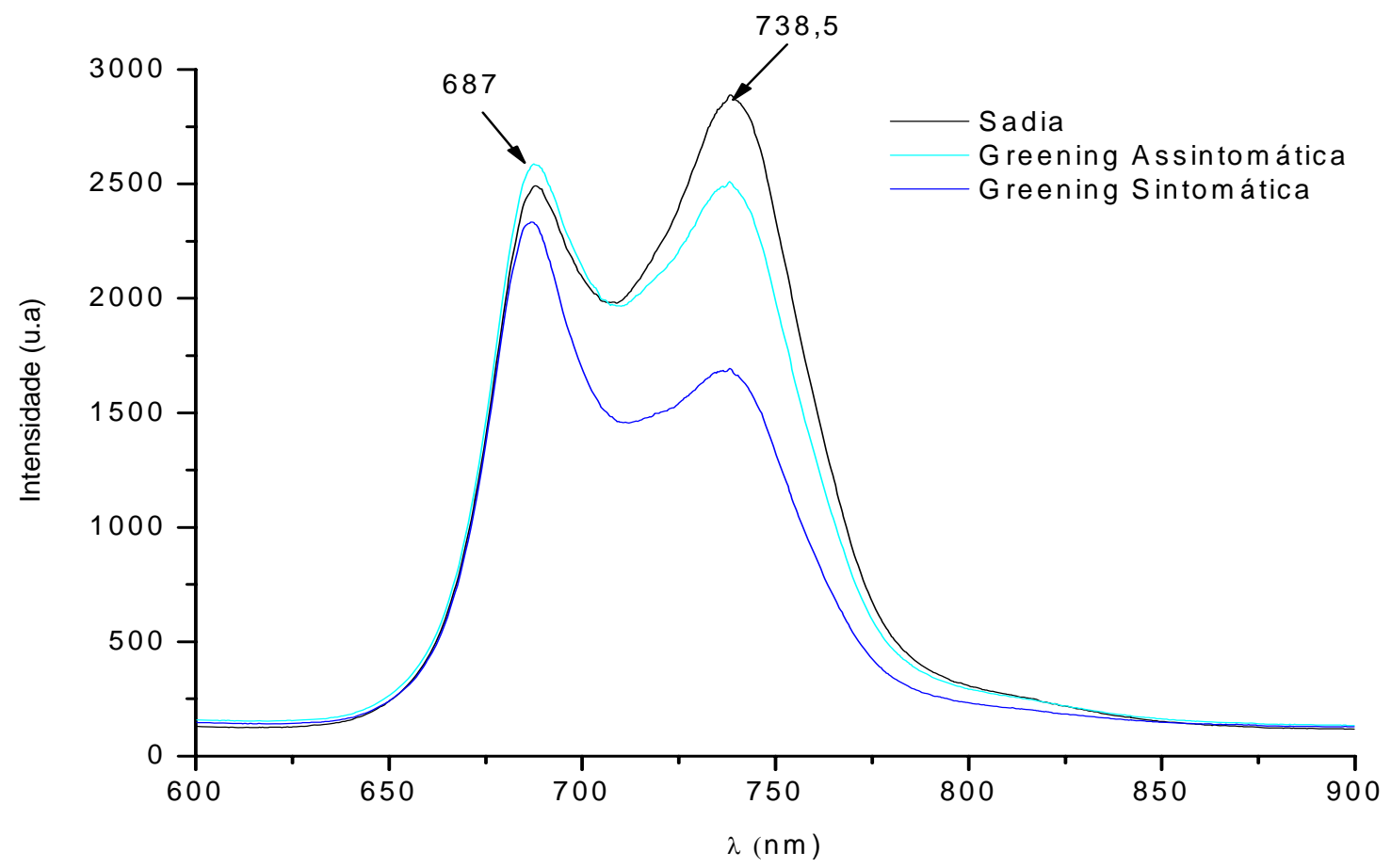

Figura 5.17 - Espectro típico de emissão de fluorescência de folhas de laranja Pêra em portaenxerto de tangerina Sunki em plantas irrigadas, obtidos através do sistema portátil de FIL desenvolvido e construído no LOLEIA.

Segundo informações do gráfico acima as amostras com GA e GS possuem o pico de 687 nm mais intenso que o pico de $738 \mathrm{~nm}$, no GA a diferença é sutil já para o GS essa diferença é bastante acentuadas e uma inversão ocorre em amostras saudáveis. Fez-se também um gráfico de PCA dessas amostras visando melhor entendimento dos dados (Figura 5.18) 


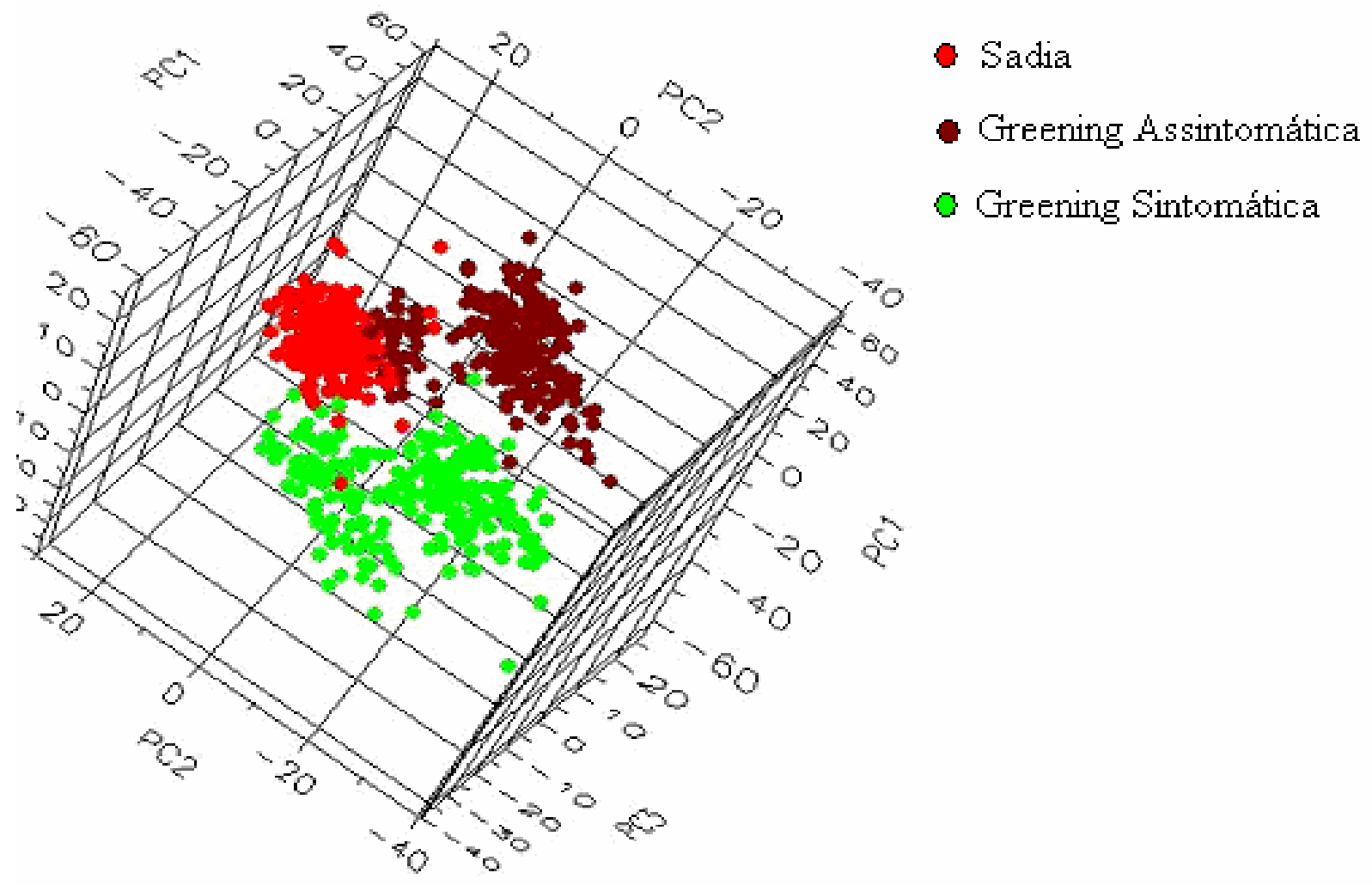

Figura 5.18 - Gráfico de PCA gerado através dos espectros de emissão de fluorescência de folhas de laranjeira Pêra em porta-enxerto de tangerina Sunki em plantas irrigadas, obtidos através do sistema portátil de FIL desenvolvido e construído no LOLEIA em plantas contaminadas com GA, GS e plantas sadias.

O gráfico da PCA mostrou a formação de três grandes grupos para cada classe de folhas analisadas. Um seleto grupo de plantas sadias encontra-se em uma região próxima a plantas com GA e esta informação é bastante interessante, pois nos dá a idéia de uma possível identificação precoce da doença.

Analisando o gráfico como um todo é possível distinguir plantas sadias de plantas com GA e GS com aproximadamente $95 \%$ de acerto. 


\subsubsection{NATAL}

Fez-se um estudo também com laranja Natal utilizando limoeiro Cravo como portaenxerto devido ao seu grande uso na citricultura brasileira. O gráfico da figura 5.19 mostra o espectro de típico obtido a partir do sistema portátil de fluorescência induzida por laser. Esse conjunto de dados possui amostras sadias, com Declínio e com os dois níveis de severidade da MSC.

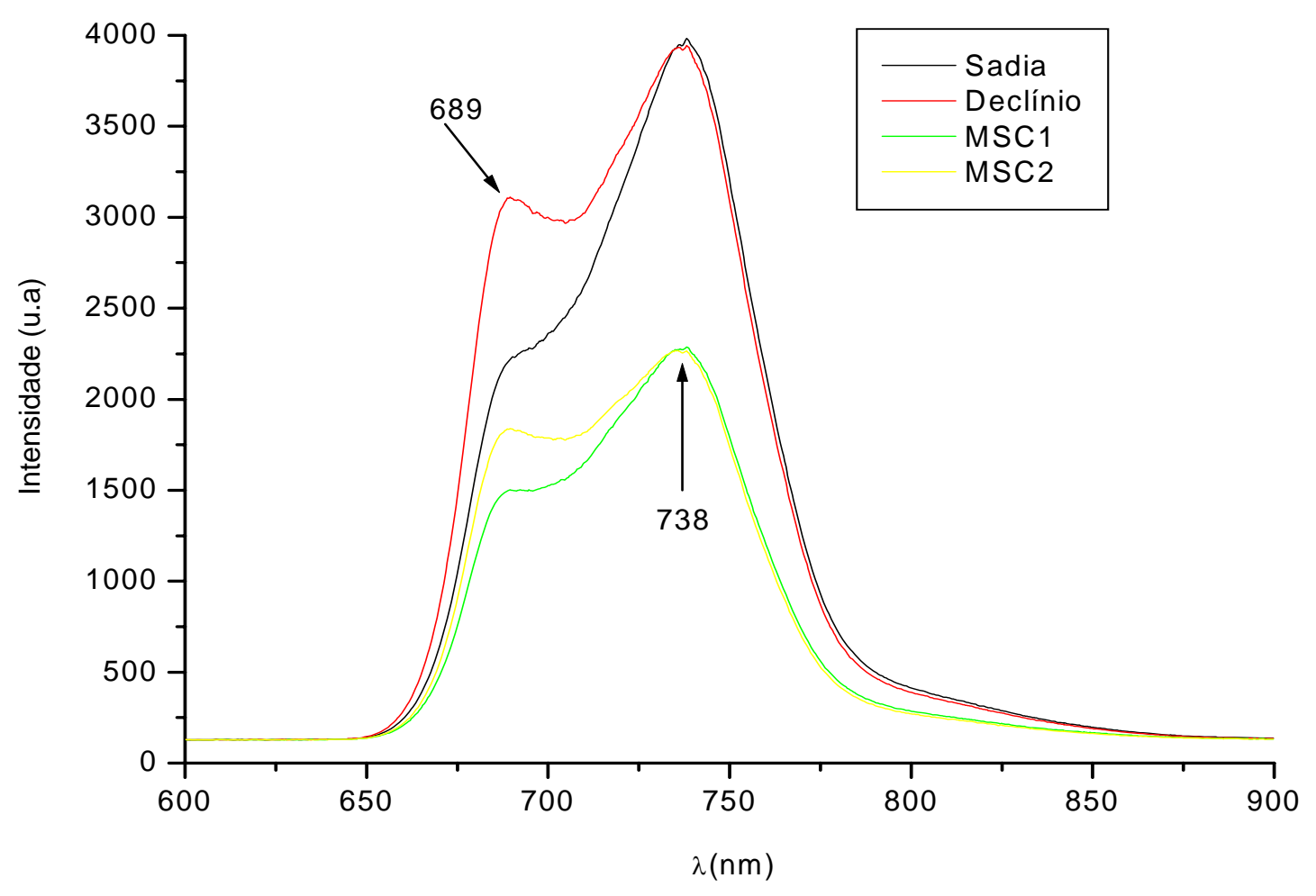

Figura 5.19 - Espectro típico de emissão de fluorescência de folhas de laranjeira Natal em portaenxerto de limão Cravo coletadas em estação chuvosa, obtido através sistema portátil desenvolvido e construído no LOLEIA.

Nos espectros obtidos é possível observar claramente uma maior intensidade do pico em 738nm e os espectros deixam claro que há uma diferença de intensidade espectroscópica entre as 
doenças e os diferentes níveis de severidade de MSC. A partir desses espectros fez-se um gráfico de PCA para ver se era possível diferenciar as doenças (Figura 5.20).

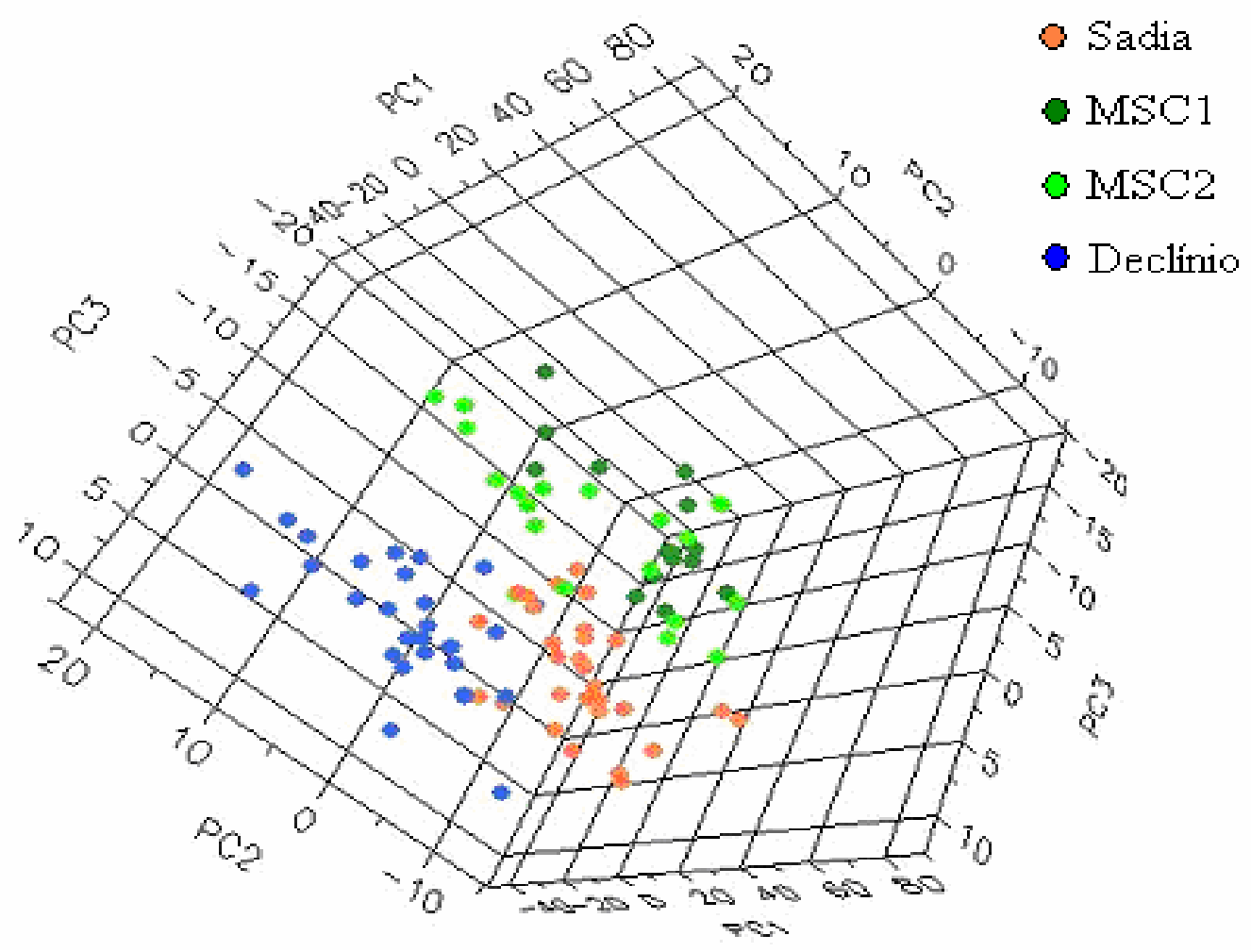

Figura 5.20 - Gráfico de PCA gerado através dos espectros de folhas de laranjeira Natal em portaenxerto de limão Cravo coletadas em estação de chuva, obtido através do sistema portátil FIL desenvolvido e construído no LOLEIA em plantas contaminadas com MSC1, MSC2, Declínio e plantas sadias.

Analisando detalhadamente o gráfico de PCA é possível separar em sua totalidade folhas de plantas com MSC e Declínio e acima de $95 \%$ as plantas ditas assintomática com das demais doenças. É possível também observar a as plantas com diferentes níveis de MSC ficam próximas uma das outras. 
Uma outra combinação de porta-enxerto foi estuda para a mesma variedade de laranjeira Natal, o porta-enxerto é a Poncirus Trifoliata. O estudo foi feito apenas para amostras contendo GS e folhas sadias coletadas na mesma região (Figura 5.21).

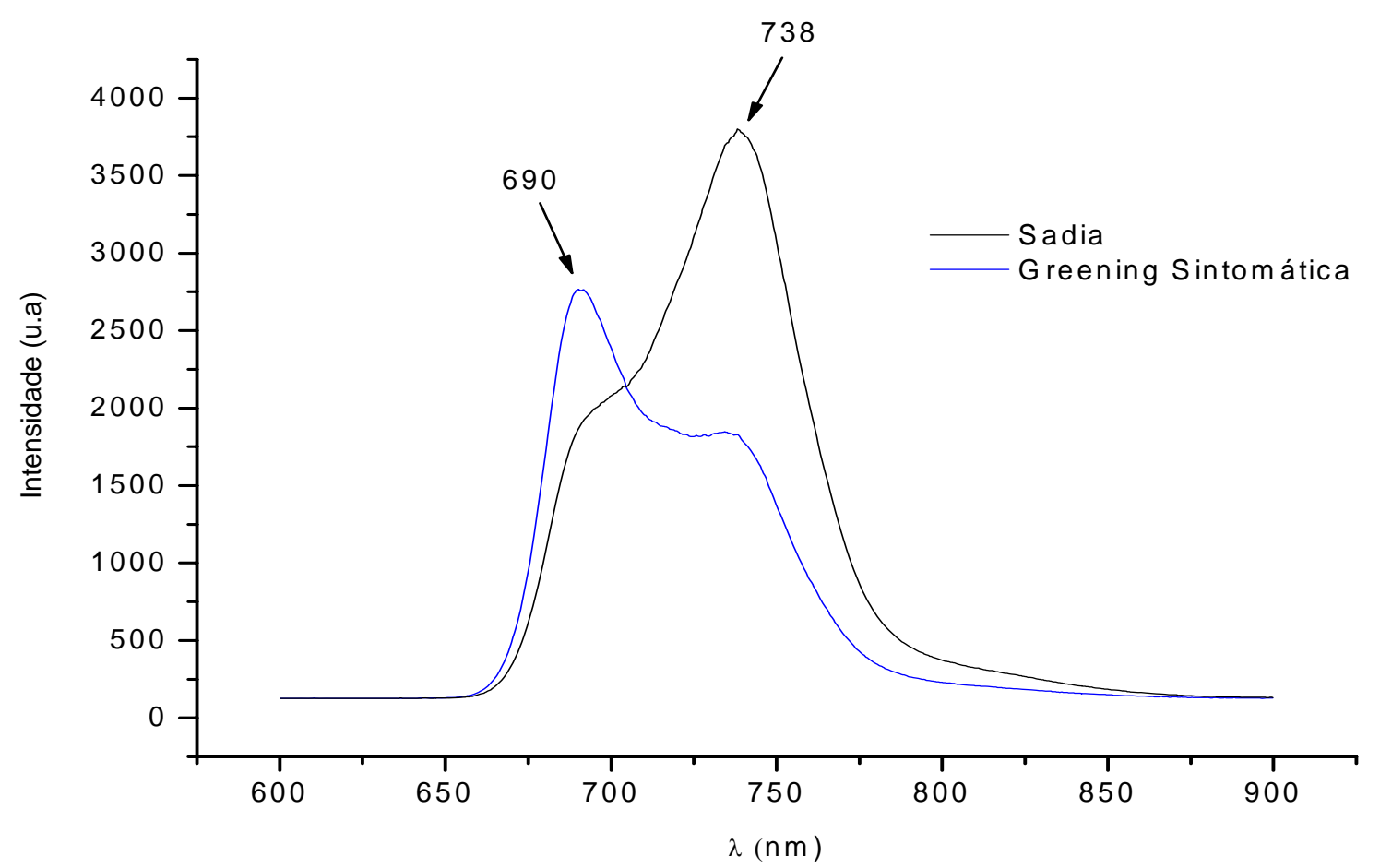

Figura 5.21 - Espectro típico de emissão de fluorescência de folhas de laranja Pêra em portaenxerto de Poncirus Trifoliata em plantas irrigadas, obtidos através do sistema portátil de FIL desenvolvido e construído no LOLEIA.

Observando este espectro é fácil notar uma inversão de máximos para as diferentes classes de amostras. Amostras com GS possuem um comportamento inverso. O gráfico de PCA deste conjunto de amostras esta representado pela figura 5.22, onde é possível observar a formação de dois grupos distintos, classificando assim as amostras em 100\% de acerto. 


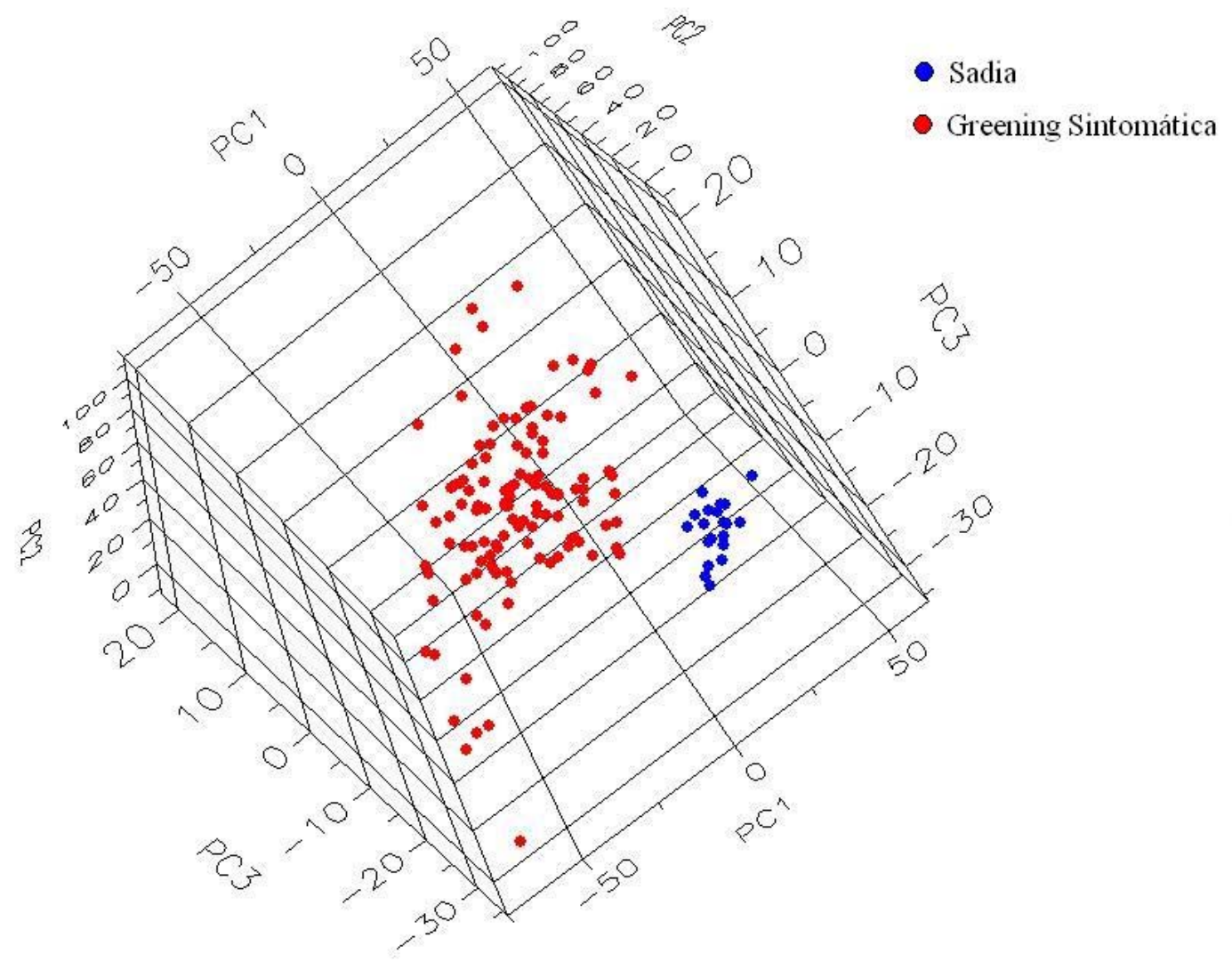

Figura 5.22 - Gráfico de PCA gerado através dos espectros de emissão de fluorescência de folhas de laranjeira Natal em porta-enxerto de Poncirus Trifoliata em plantas irrigadas, obtidos através do sistema portátil de FIL desenvolvido e construído no LOLEIA em plantas contaminadas com GA e plantas sadias.

Outro porta-enxerto utilizado também foi o Citrumelo Swingle com a mesma variedade natal. O conjunto de amostras possui folhas sadias, folhas com GA, GS e folhas amarelas, mas devida a outras deficiências que não seja Greening. O PCA dessas amostras nos mostrou uma separação em 100\% em relação à sadia, e também conseguiu ma separação entre folhas amareladas contaminadas com Greening e folhas amareladas por alguma deficiência (Figura 5.23). 


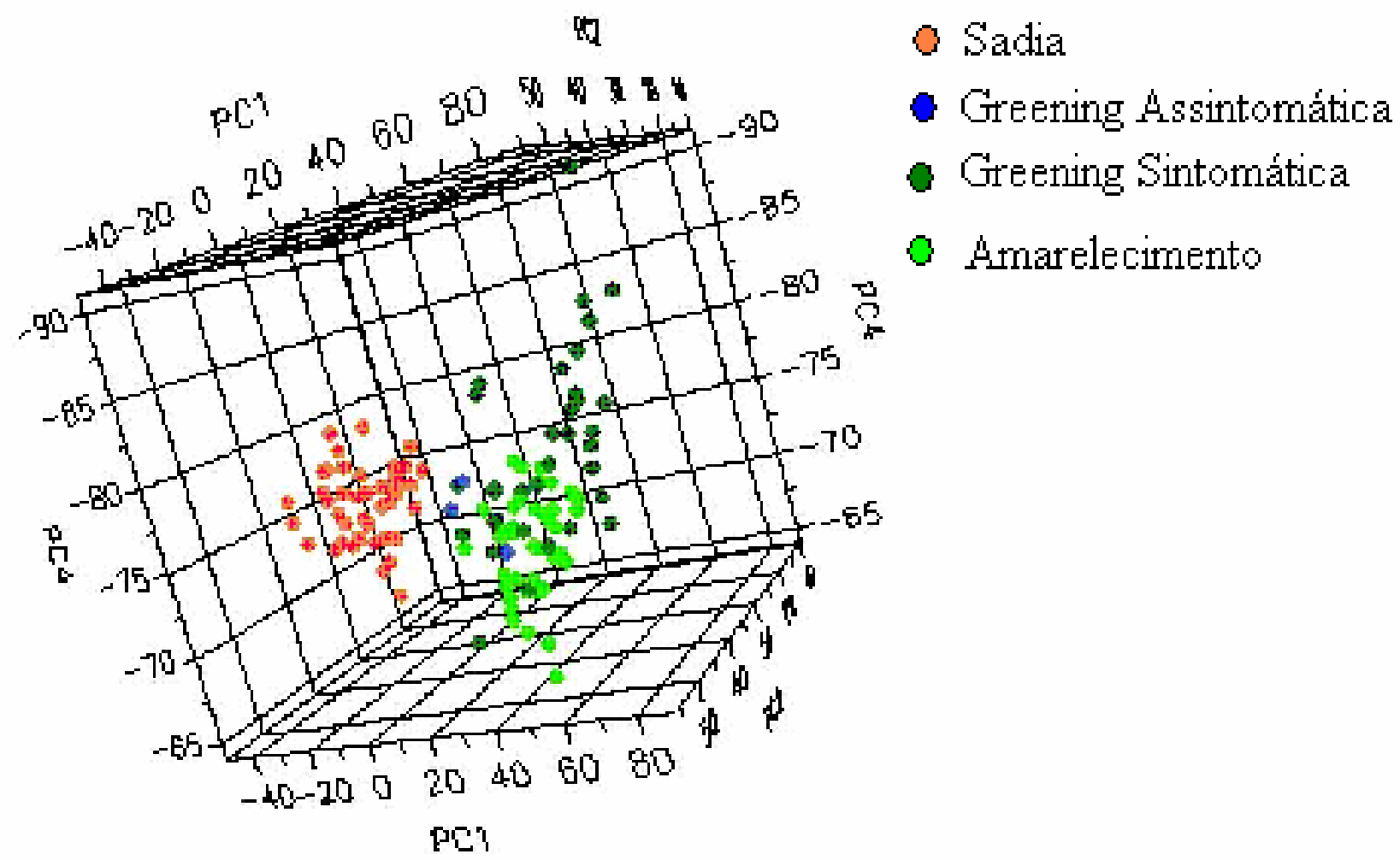

Figura 5.23 - Gráfico de PCA gerado através dos espectros de emissão de fluorescência de folhas de laranjeira Natal em porta-enxerto de Citromelo Swingle em plantas irrigadas, obtidos através do sistema portátil de FIL desenvolvido e construído no LOLEIA em plantas contaminadas com GA, GS, Amarelecimento e plantas sadias.

Todos os dados apresentados nessa seção deixam claro a sensibilidade da técnica de fluorescência onde mostra que mesmo com diferentes combinações de copa e porta-enxerto é capaz de diferenciar as doenças de citros (MSC, Declínio, Greening assintomáticae Greening sintomática) com uma precisão sempre superior a 93\% . 


\section{CAPÍTULO 6}

CONCLUSÃO

Os estudos realizados no presente trabalho trouxeram informações bastante relevantes para o entendimento das alterações causadas pela MSC, pelo Declínio, pelo GA e GS nas plantas de citros.

Quanto aos resultados provenientes dos estudos realizados nos extratos fotossintéticos pode-se concluir que plantas com a mesma variedade de copa em diferente porta-enxerto não são quimicamente iguais. Com base nos extratos também se pode dizer que as concentrações das clorofilas a e b variam de forma diferente conforme as doenças e que a clorofila a é que mais sofre essas alterações. Plantas com Declínio aumentam em 17\% a intensidade de emissão da clorofila, já plantas com MSC, GS e GA reduzem em até 76\% como é o caso da GS. Parece que ao ser infectada, a planta tenta reagir e essa revolução interna da planta, embora assintomática ao olho humano, é observada por seu espectro de emissão de fluorescência.

Os resultados provenientes das folhas trouxeram informações que vieram a corroborar com as informações obtidas dos extratos fotossintéticos. As doenças não apenas alteram a fluorescência como um todo, mas causam também deformações espectrais geradas pelas diferentes proporções entre as clorofilas a e b. As alterações espectrais foram tão significativas que através da técnica de espectroscopia de fluorescência induzida por laser foi possível determinar as doenças estudas em diferentes níveis de severidade, como foi o caso de da MSC e da GA e GS. 
Uma outra conclusão que se pode chegar através do referido estudo é que os espectros de emissão de fluorescência são mais bem definidos quanto a sua forma e intensidade de sinal na estação chuvosa.

Com os índices de diferenciação de doenças acima de 93\% de acerto, a espectroscopia de fluorescência induzida por laser aliada ao método quimiométrico de PCA mostrou-se bastante eficiente, principalmente entre amostras de folhas sadias e folhas com Greening Assintomática são um indicativo que a metodologia é bastante promissora, sendo capaz de substituir os métodos atuais de inspeção visual. Além do mais, trata-se de uma metodologia não invasiva, e por isso evita procedimento como o corte feito na região de enxertia para detectar a MSC. Esta metodologia também é economicamente viável quando comparada às análises de PCR feitas para o diagnóstico da Greening. As análises de PCR comum levam 15 dias para obtenção de um resultado e são capazes de diagnosticar $56 \%$ dos casos na fase assintomática da doença. A análise de PCR de tempo real tem uma sensibilidade muito superior, conseguindo fazer o doagnótico ainda na fase assintomática, entretanto não é uma técnica viável para inspeção em função dos custos.

Os resultados deste trabalho devem contribuir com a citricultura brasileira, pois apresentam uma forma de diagnóstico não invasiva, objetiva e economicamente viável para o Greening, MSC e Declínio. Entretanto, considerando a gravidade atual da doença Greening, a maior contribuição deve ser o diagnóstico do Greening em folhas assintomática, ou seja, em folhas de árvores contaminadas com a doença, mas que ainda não houve a expressão dos sintomas. 
- Identificação de outras variedades e porta-enxerto tanto para estudos dessas mesmas doenças como para diferenciação de mudas.

- Desenvolver um mapa do pomar com diagnóstico de sanidade do mesmo

- Fazer estudos diretamente no campo com o protótipo desenvolvido

- Fazer testes com LEDs 


\section{CAPÍTULO 8}

\section{REFERENCIA BIBLIOGRÁFICA}

ABADPOUR, A.; KASAEI, S. Color PCA eigenimages and their application to compression and watermarking. Image and vision computing, v. 26, p. 878, 2008.

ABBAS, O.; REBUFA, C.; DUPUY, N.; PERMANYER, A.; KISTER, J. Assessing petroleum oils biodegradation by chemometric analysis of spectroscopic data. Talanta, v. 75, p. 857, 2008.

ARNON, A. Photosynthetic electron-transport - emergence of a concep. Photosynthesis

Research, v. 29, p. 117-131, 1949.

AYRES, A. J. Situação atual do HLB no Estado de São Paulo, Brasil. Huanglongbing Greening International Workshop, v. 1, p. 12, 2006.

BARROS, C. C. P.; JESUS JUNIOR,W. C.; TEIXEIRA, D.C., GOMES, C. C.; DUTRA, L. S., NAGATA, T. Molecular characterization of tymo-like isolated from orange trees with sudden death disease symptom. Fitopatologia Brasileira, v. 29, p. 278, 2004.

BASSANEZI, R. B. Evolução da morte súbita no Estado de São Paulo e estimativas de danos. In: SEMANA DA CITRICULTURA, 26., 2004,Cordeiropolis. Anais... Cordeirópolis: Semana da Citricultura, 2004. v. 26, p.78.

BASSANEZI, R. B.; YAMAMOTO, P. T.; GIMENES-FERNANDES, N. Progresso dos sintomas de "morte súbita" em pomares de laranjeiras 'Valência' e 'Pêra-Rio' (Resumo). Summa Phytopathologica, v. 28, n .1, p. 73, 2002.

BASSANEZI, R. B.; BERGAMIN FILHO, A.; AMORIN, L; GIMENES-FERNADES, N., GOTTWALD, T. R.; BOVÉ, J. M. Spatial and Temporal Analyses of Citrus Sudden Death as a Tool to Generate Hypoteses Concerning is Etiology. Phytopatology, v. 93, p. 502-512, 2003. 
BASSANEZI, R. B.; BUSSATO, L. A.; SANCHES, A. L.; BARBOSA, J. C. Danos da morte súbita dos citros sobre a produção de laranja. Fitopatologia Brasileira, v. 30, p. 497-503, 2005. BEATTIE, J. H.; GORDON, M. J.; RUCKLIDGE, G. J.; REID, M. D.; DUNCAN, G. J.; HORGAN, G. W.; CHO, Y. E.; KWUN, I. S. Aorta protein networks in marginal and acute zinc deficiency. Proteomics, v. 8, p. 2126, 2008.

BERGAMIN FILHO, A; JESUS JUNIOR, W. C.; YAMAMOTO, P. T.; BASSANEZI, R. B. Morte súbita dos citros. In: CONGRESSO BRASILEIRO DE FITOPATOLOGIA, 37., 2004, Fortaleza. Anais... Fortaleza: Sociedade Brasileira de Fitopatologia, 2004. v. 29, p. S18-S22.

BERNSMANN, F.; LAWRENCE, N.; HANNIG, M.; ZIEGLER, C.; GNASER, H. Protein films adsorbed on experimental dental materials: ToF-SIMS with multivariate data analysis. Analytical and bioanalytical chemistry, v. 391, p. 545, 2008.

BOTEON, M.; VIDAL, A . J. Citricultura no Brasil e na Flórida. Citricultura Atual, n. 23, p. 3, 2001.

BOVÉ, J. M. Huanglongbing: a destructive, newly-emerging, century-old disease of citrus. Journal Plant Pathology, v. 38, p. 7-37, 2006 a.

BOVÉ, J. M. History, aetiology, field identification, transmission, and wold distribution of huanglongbing: a destructive, newly-emerging, century-old disease of citrus. Huanglongbing Greening International Workshop, v. 1, p. 1, $2006 \mathrm{~b}$.

BOVÉ, J. M.; GARNIER, M.; GIMENES-FERNANDES, R. B.; YAMAMOTO, P. T.; AYRES, A. J. Sudden death disease (morte subita doença) of sweet oranges trees on ranpur lime: a hypothesis. Report to Fundecitrus, v. 113, p. 23-25, 2002.

BUSCHMANN, C.; LANGSDORF, G.; LICHTENTHALER, H. K. Imaging of the blue, green and red fluorescence emission of plants: an overview. Photosynthetica, v. 38, p. 483-491, 2000.

CHEN, J.; LEBOEUF, E.; DAI, S.; BAOHUA, G. Fluorescence spectroscopic studies of natural organic matter fractions. Chemosphere, v. 50, p. 639-647, 2003.

CITRUS. AGRIANUAL 2003: anuário da agricultura brasileira. São Paulo: FNP Consultoria e Agroinformativos, 2003 p. 295-314. 
DEELL, J. R.; TOIVONEN, P. M. A. Chlorophyll fluorescence as a nondestructive indicator of broccoli quality during storange in modified-atmosphere packaging. HortScience, v. 35, p. 256259,2000 .

DERRICK, K. S.; BERETTA, M. J.; BARTHE,G. A.; KAYIM, M.; HARAKAVA, R. Identification of strain of citrus tristeza virus by substraction hybridization. Plant Disease, v. 87, p. 1355-1359, 2003.

FUNDECITRUS. Manual de Greening. Araraquara: Fundecitrus, 2007. Disponível em: < http://www.fundecitrus.com.br/manuais/fdc_manual_greening_0307.pdf $>$. Acesso em: 17 mar. 2008a.

FUNDECITRUS. Manual de MSC: morte súbita dos citros. Araraquara: Fundecitrus, 2007. Disponível em: $<$ http://www.fundecitrus.com.br/manuais/fdc_manual_msc_0406.pdf $>$. Acesso em: 17 de mar. 2008b.

GASPAROTO, M. C. G. Relação entre a espectroscopia de fluorescência, fotossíntese e severidade do cancro cítrico (Xanthomonas axonopodis pv. Citri). 2006. 64 f. Dissertação (Mestrado)- Escola Superior de Agricultura Luiz de Queiroz, Universidade de São Paulo, Piracicaba, 2006.

GIMENES-FERNANDES, N.; BASSANEZI, R. B. Doença de causa desconhecida afeta pomares cítricos no norte de São Paulo e sul do Triângulo Mineiro. Summa Phytopathologica, v. 27, n. 1, p. 93, 2001.

GIMENES-FERNANDES, N.; BASSANEZI, R. B.; YAMAMOTO, P. T.; AYRES, A. J. Árvore de limoeiro 'Cravo'não mostram sintomas de "morte súbita" em área afetada. Summa Fitopatology, v. 28, p. 72, 2002.

GOODWIN, R. H. Fluorescent substances in plants- Annu. Rev. Plant Physiology, v. 4, p. 283304, 1953.

HAMMOND, R. W.; RAMIREZ, P. Molecular characterization of the genome of Maize rayado fino virus, the type member of the genus Marafivirus. Virology, v. 282, p. 338-347, 2001.

HARAKAVA, R. Obtenção de sequências de um vírus do gênero Marafivirus a partir de laranjeira com sintomas de morte súbitas dos citros. Summa Phytopathologica, v. 30, p. 101, 2004. 
INFORMATIVO CENTRO DE CITRICULTURA. Informativo: nova doença já causa prejuízo a pomares de SP e MG. Informativo Centro de Citricultura, v. 76, p. 1-4, 2001.

ISHIDA, F. Y.; OLIVEIRA, L. E. M.; CARVALHJO, C. JU. R.; ALVES, J. D. Efeito da imunização parcial e total sobre o crescimento, teor de clorofila e fluorescência de Setaria anceps e Paspalum repenses. Ciência Agrotenica, v. 26, p. 1152-1159, 2002.

JESUS JUNIOR, W. C.; BASSSNEZI, R. B. Análise da dinâmica e estrutura de focos da morte súbita dos citros. Fitopatologia Brasileira, v. 29, p. 399-405, 2004a.

JESUS JUNIOR, W. C.; BASSSNEZI, R. B.; BERGAMIN FILHO, A. Morte súbita dos citros ainda tem origem desconhecida. Visão Agrícola, v. 1, p. 34-39, 2004 b.

JESUS JUNIOR, W. C.; YAMAMOTO, P. T.; BASSANEZI, R. B.; BERGAMIM FILHO. A morte súbita dos citros. In: ZAMBOLIM, L. (Ed.). Manejo integrado de doenças e pragas: produção integrada de fruteira tropicais. Visconde do Rio Branco: Suprema Gráfica e Editora, 2003. p. 187-222.

JOHNSON, G. A.; MANTHA, S. V.; DAY, T. A. A spectrufluorimétric survey of UV-induced blue-green fluorescence in foliage of 35 species. Journal Plant Physiology, v. 156, p. 242-252, 2000 .

KIMATI, H.; GALLI, F. Doença da de citros. In: GALLI, F. ( Coord. ). Manual de fitopatologia: doenças de plantas cultivadas. São Paulo: Ed. Agronômica Ceres, 1980. v. 2, p. 213-235.

KOBAYASHI, R.; OKAMOTO, R.A.; Maddalena, R.; KADO, N. Y. Polycyclic aromatic hydrocarbons in edible grain: A pilot study of agricultural crops as a human exposure pathway for environmental contaminants using wheat as a model crop. Environmental Research, v. 107, p. 145, 2008.

KRAUSE, G. H. Chlorophyll Fluorescence and photosynthesis: The basics. Plant Physiology, v. 42, p. 313-349. 1991.

LANG, M.; LICHTENTHALER, H. K.; SOWINSKA, M.; HEISEL, F.; MIHÉ, J. A. Fluorescence imaging of water and temperature stress in plants leaves. Journal Plant Physiology, v. 148, p. 613-621, 1996. 
LANG, M.; LICHTENTHALER, H. K.; SOWINSKA, M.; SUMM, P.; HEISEL, F. Blue, green and red fluorescence signatures and images of tobacco leaves. Botanic Acta, v. 107, p. 230-236, 1994.

LANG, M.; STOBER, F.; LICHTENTHALER, H. K. Fluorescence emission spectra of plant leaves and plant constituents. Radiat. Environment Biophysica, v. 30, p. 333-347, 1991.

LIBARONE, A. C.; MASSARI, C. A.; BASSANEZI, R. B.; YAMAMOTO, P. T.; GIMENESFERNANDES, N.; AYRES, A. J. Levantamento da ocorrência da "morte súbita dos citros" no Estado de São Paulo e sul do Triangulo Mineiro. Summa Phytopathologica, v. 28, p. 72-73, 2002.

LICHTENTHALER, H. K. The Kautsky effect: 60 years of chlorophyll fluorescence induction kinetics. Photosynthetica, v. 27, p. 45-55, 1992.

LICHTENTHALER, H. K.; BABANI, F. Detection of photosynthetic activy and water stress by imaging the red chlorophyll fluorescence. Plant Physiology Biochemist, v. 38, p. 889-895, 2000a.

LICHTENTHALER, H. K.; BABANI, F.; LANGSDORF, G.; BUSCHMANN, C. Measurement of differences in red chlorophyll fluorescence and photosynthetic activity between sun and shade leaves by fluorescence imaging. Photosynthetica, v. 39, p. 523-531,2000b.

LUMB, M. D. Luminescence spectroscopy. New York: Academic Press, 1978. p.375.

MACCHERONI W.; ALEGREIA, M. C.; GREGGIO, C. C.; PIAZZA, J. P.; KAMILA,R.F.; ZACARIAS, P .R. A.; BAR-JOSEPH, M.; KITAJIMA,E. W.;ASSUMPÇÃO, L. C.; CAMAROTTE, G.; CARDOSO, J.; CASAGRANDE, E. C.; FERRARI, F.; FRANCO, S.F.; GIACHETTO, P.F.; GIRASOL, A.; JORDÃO JR, H.; SILVA, V. H. A.; AGUILAR-FERRO, J. A.; SILVA, A. C. R. Identification and genomic characterization of a new vírus (Tymoviridae Family) associated with Citrus Sudden Death Diasse. Journal of Virology, v. 9, n. 5, p. 30283037, 2005.

MARAUN, D; OSBORN, T. J.; GILLETT, N. P. United Kingdom daily precipitation intensity: improved early data, error estimates and an update from 2000 to 2006. International Journal of Climatology, v. 28, p. 833, 2008. 
MARCASSA, L. G.; GASPAROTO, M. C. G.; BASQUETE JUNIOR, J.; LINS, E. C.; NUNES, D. F.; BAGNATO, V. S. Fluorescence spectroscopy applied to orange trees. Laser Methods in Biology and Medicine, v. 16, p. 884-888, 2006.

MAXWELL, K.; JOHSON, G. N. Chlorophyll fluorescence- a practical guide. Journal of Experimental Botany, v.51, n. 345, p. 659-668, 2000.

MORALES, F.; CEROVENIC, Z. G.; MOYA, I. Times-resolved blue-green fluorescence of sugar beet (Beta vulgaris L.) leaves. Spectroscopic evidence for the presence of ferulic acid as the main fluorophore of the epidermis. Biochimica Biophysica Acta, v. 1273, p. 251-262, 1996.

MULLER, G. W.; DE NEGRINI, J. D.; AGUILAR-VILDOSO, C. I.; MATTOS JR, D.; POMPEU JUNIOR, J.; TÓFILO, S. J.; CARVALHO, S. A.; GIROTTO, L. F.; MACHADO, M.A. Morte súbita dos citros: uma nova doença na citricultura brasileira. Laranja, v. 23, p. 371386, 2002.

PIGANI, L.; FOCA, G.; IONESCU, K.; MARTINA, V.; ULRICI, A.; TERZI, F.; VIGNALI, M.; ZANARDI, C.; SEEBER, R. Amperometric sensors based on poly (3,4-ethylenedioxythiophene)modified electrodes: Discrimination of white wines. Analytica Chimica Acta, v. 614, p. 213, 2008.

POMPEU JÚNIOR, J. Porta-Enxertos. In: RODRIGUEZ, O.; VIÉGAS, F.; POMPEU JUNIOR, J., AMARO, A. A. Citricultura Brasileira. Campinas: Fundação Cargill, v. 01, p. 265-280, 1991.

ROMAN, M. P.; CAMBRA, M.; JUAREZ, J.; MORENO, P.; DURAN-VILA, N.; TANAKA, F. A. O.; ALVES, E.; KITAJIMA, E. W.; YAMAMOTO, P. T.; BASSANEZI, R. B.; TEIXEIRA, D. C.; JESUS JUNIOR, W. C.; AYRES, A. J.; GIMENES-FERNANDES, N.; RABENSTEIN, F.; GIROTTO, L. F.; BOVE, J. M. Sudden death of citrus in Brazil: A graft-transmissible bud union disease. Plant Disease, v. 88, p. 453-467, 2004.

SAAKOV, V.; LANG, M.; SCHINDLER, C.; STOBER, F.; LICHTENTHALER, H. K.Changes in chlorophyll fluorescence an photosynthetic activity of French bean leaves induced by gamma radiation. Photosynthetica, v. 27, p. 369-383, 1992.

SCHREIBER, U.; BILGER, W. Rapid assessment of stress effects on plant leaves by chlorophyll fluorescence measurements. In: TENHUNSEN, J. D.; CATARINO, F. M.; LANGE, O. L.; OECHEL, W. C. (Eds.). Plant response to stress-funcional analysis in mediterranean 
ecosystems. Heidelberg: Springer Verlag, 1987. p. 27-57 (Nato Advanced Science Institute Series ).

SENESI, N.; STEELINK, C. Application of ESR spectroscopy to the study of humic substances. In: HAYES, M. H. B.; MACCARTHY, P.; MALCOLM, R. L.; SWIFT, R. S. (Eds.). Humic substances II: in search of structure. New York: John Wiley, 1989. p. 373-407.

SETIN, D. W. Porta-enxertos múltiplos de limoeiro 'Cravo' e citrumeleiro 'Swingle'em laranjeira 'Valência'. 2007. 62 f. Dissertação (Mestrado) - Tecnologia da Produção AgrícolaInstituto Agronômico, Campinas, 2007.

STREIT, N. V.; CANTERLE, L. P.; CANTO, M. W.; HECKTHEUER, L. H. H. As clorofilas. Ciência Rural, v. 35, p. 748-755, 2005.

TARGON, M. L.P.N.; ASTUA-MONGE, G.; FREITAS-ASTUA, J.; KISHI, L.; SOUZA, A. A.; SANTOS, F. A.; MULLER, G. W.; MACHADO, M. A. Evaluation of CTV haplotypes in plants exhibiting citrus sudden death symptoms. In: INTERNATIONAL CONGRESS OF CITRICUlTURE, 10., 2004, Marrocos. Program and Abstracts... Marrocos: International Society of Citriculture, 2004. p. 98.

TERENCIO, J. C.C. Detecção precoce da morte súbita dos citros usando fluorescência. 2006. 106f. Dissertação (Mestrado em Química Analítica)- Instituto de Química de São Carlos, Universidade de São Paulo, São Carlos, 2006.

WULFF, N. A. Diagnose do huanglongbing. Huanglongbing Greening International Workshop, v. 1, p. 18, 2006.

YAMAMOTO, P. T.; JESUS JUNIOR, W.C.; BASSANEZI, R. B.; SANCHES, A. L.; AYRES, A. J.; GIMENES-FERNANDES, N.; BOVÉ, J. M. Transmission of citrus sudden death agent bygraftinoculation under insect proof conditions. Fitopatologia Brasileira, v. 29, p. 206, 2004.

YAMAMOTO, P. T.; JESUS JUNIOR, W.C.; BASSANEZI, R. B.; SANCHES, A. L.; AYRES, A. J.; GIMENES-FERNANDES, N.; BOVÉ, J. M. Transmission of the agent inducing symptoms of citrus sudden death by graft-inoculation under insect-proof conditions. Fitopatologia

Brasileira, v. 28, p. S265, 2003 